\title{
Procedural Retrenchment and the States
}

\author{
Zachary D. Clopton*
}

Although not always headline grabbing, the Roberts Court has been highly interested in civil procedure. According to critics, the Court has undercut access to justice and private enforcement through its decisions on pleading, class actions, summary judgment, arbitration, standing, personal jurisdiction, and international law.

While I have much sympathy for the Court's critics, the current discourse too often ignores the states. Rather than bemoaning the Roberts Court's decisions to limit court access-and despairing further developments in the age of Trump-we instead might productively focus on the options open to state courts and public enforcement. Many of the aforementioned decisions are not binding on state courts, and many states have declined to follow their reasoning. This Article documents state courts deviating from Twombly and Iqbal on pleading; the Celotex trilogy on summary judgment; Wal-Mart v. Dukes on class actions; and Supreme Court decisions on standing and international law. Similarly, many of the Court's highly criticized procedural decisions do not apply to public enforcement, and many public suits have proceeded where private litigation would have failed. This Article documents successful state-enforcement actions when class actions could not be certified, when individual claims would be sent to arbitration, and when private plaintiffs would lack Article III standing.

DOI: https://doi.org/10.15779/Z38QV3C40V

Copyright (C) 2018 California Law Review, Inc. California Law Review, Inc. (CLR) is a California nonprofit corporation. CLR and the authors are solely responsible for the content of their publications.

* Assistant Professor of Law, Cornell Law School. Many thanks to Sandra Babcock, Andrew Bradt, Steve Burbank, Josh Chafetz, Kevin Clermont, Michael Dorf, Heather Elliott, Cynthia Farina, Maggie Gardner, William Hubbard, Aziz Huq, Margaret Lemos, Odette Lienau, Liz McCuskey, James Pfander, Jeff Rachlinski, Teddy Rave, Judith Resnik, Lynn Stout, Jay Tidmarsh, Chuck Whitehead, Tobias Barrington Wolff, and participants in the NYU Law Review Symposium, the Law \& Society Annual Meeting, the Cornell Law School Faculty Workshop, and the Junior Federal Courts Workshop. 
In sum, this Article evaluates state court and state-enforcement responses to the Roberts Court's procedural decisions, and it suggests further interventions by state courts and public enforcers that could offset the regression in federal court access. At the same time, this analysis also illuminates serious challenges for those efforts, and it offers reasons to be cautious about state procedure and enforcement. Leveling down to state actors may not completely escape the political forces that have shaped federal procedure, and it may exacerbate some of the political economies that have undermined private enforcement and private rights to date.

Introduction

I. Procedural Retrenchment in the Roberts Court...................................416

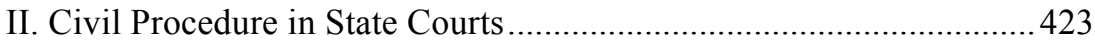

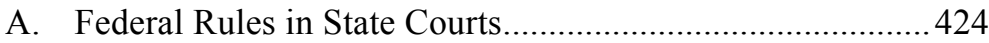

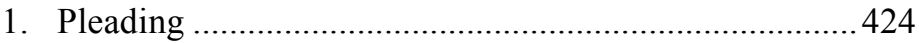

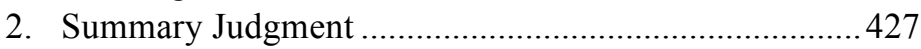

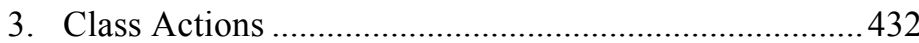

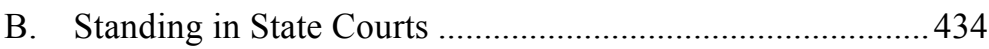

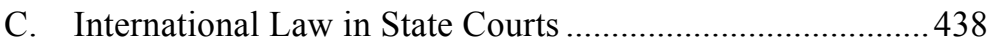

D. Personal Jurisdiction in State Courts ...................................... 441

E. State Court Assessment ....................................................... 442

III. Civil Procedure and State Enforcement ..............................................445

A. Class Action Substitutes ......................................................446

1. Attorney General Suits ...................................................446

2. Private Attorney General Suits .......................................450

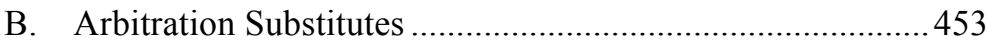

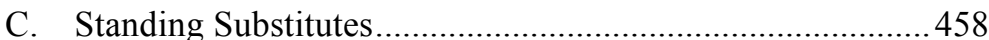

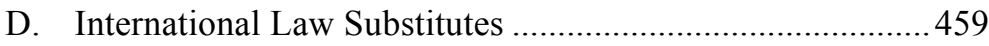

E. Personal Jurisdiction Substitutes .............................................460

F. State-Enforcement Assessment...............................................461

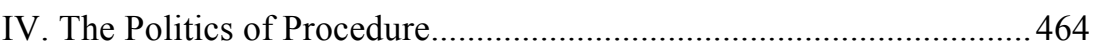

A. Reasons for Optimism .........................................................464

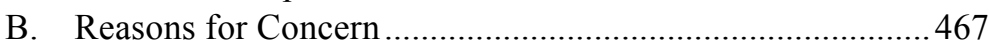

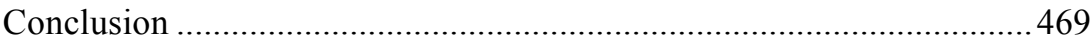

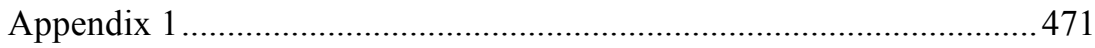

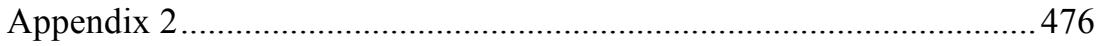




\section{INTRODUCTION}

Although not always headline grabbing, the Roberts Court has been highly interested in civil procedure. ${ }^{1}$ And, at least in some quarters, it has been seen as brutally effective in pursuing substantive values through its civil procedure decision-making. ${ }^{2}$ In the words of Dean Erwin Chemerinsky:

One crucial aspect of the Roberts Court's decision making has been its systematically closing the courthouse doors to those suing corporations, to those suing the government, to criminal defendants, and to plaintiffs in general. Taken together, these separate decisions have had a great cumulative impact in denying access to the courts to those who claim that their rights have been violated. The Roberts Court often has been able to achieve substantive results favored by conservatives through these procedural devices. ${ }^{3}$

According to critics such as Chemerinsky, the Roberts Court has undercut access to justice and private enforcement through a host of decisions relating to pleading, class actions, summary judgment, arbitration, standing, personal jurisdiction, and international law. ${ }^{4}$ These decisions are consistent with the recent history of "plaintiphobia" in the Supreme Court. ${ }^{5}$ And the election of Donald Trump does not bode well for reversals in these areas. ${ }^{6}$

While I have much sympathy for these normative critiques, we should not read the Supreme Court's decisions on private federal litigation for more than they are worth. Many of the Court's procedural decisions leave open important opportunities in the states. Consider the following examples from state courts:

- Twombly and Iqbal introduced "plausibility pleading" into federal procedure, but judges in nineteen states expressly rejected this new pleading standard - not to mention other state judges who have rejected the Celotex trilogy on summary judgment, Wal-Mart v. Dukes on class actions, and others; ${ }^{7}$

- The Supreme Court tightened restrictions on Article III

1. See, e.g., Howard M. Wasserman, The Roberts Court and the Civil Procedure Revival, 31 ReV. Litig. 313 (2012); Elizabeth G. Porter, Pragmatism Rules, 101 CORNELL L. REV. 123 (2015).

2. See infra Part I (collecting sources).

3. Erwin Chemerinsky, Closing the Courthouse Doors, 90 DENV. U. L. REV. 317, 317 (2012).

4. See infra Part I (collecting cases). Access to justice refers to the ability of individuals or groups to seek and obtain a remedy through institutions of law. See generally DEBORAH L. RHODE, ACCESS TO JUSTICE (2004). Private enforcement refers to a subset of civil cases in which "government responds to a perception of unremedied systemic problems by creating or modifying a regulatory regime and relying in whole or in part on private actors as enforcers." Stephen B. Burbank et al., Private Enforcement, 17 LEWIS \& CLARK L. REV. 637, 639-40 (2013). These concepts often (though not always) run together. See infra note 453.

5. See Theodore Eisenberg \& Kevin M. Clermont, Plaintiphobia in the Supreme Court, 100 CORNELL L. REV. 193 (2014) (discussing decisions of the Roberts and Rehnquist Courts that are adverse to plaintiff interests).

6. Cf. Robert H. Klonoff, Class Actions Part II: A Respite from the Decline, 92 N.Y.U. L. REV. 971 (2017) (observing respite from the hostility toward class actions in the eight-member Court).

7. See infra Part II.A. 
standing, but state courts with looser standing rules have heard claims under Section 1983, the Americans with Disabilities Act (ADA), and other federal laws when there would have been no standing in federal court; ${ }^{8}$ and

- Medellin v. Texas declined to require evidentiary hearings for habeas petitioners claiming violations of the Vienna Convention on Consular Relations, but courts in at least two states, as a matter of state law, have ordered such hearings to vindicate the United States' international law commitments.

Or, consider the following examples of state public enforcement:

- A federal district court denied class certification in a suit against $\mathrm{H} \& \mathrm{R}$ Block regarding Refund Anticipation Loans (RALs), but the decision mentioned that public enforcement was available - and a state later sued H \& R Block over its RALs program; ${ }^{10}$

- In various decisions, the Supreme Court has made it more difficult for individuals who signed arbitration clauses to vindicate their rights in court, but public enforcers have succeeded with court actions despite arbitration clauses $;{ }^{11}$ and

- A federal court in California recently relied on Dukes to deny certification for an employment class action, but it allowed the named plaintiff to proceed on behalf of employees for "private attorney general" claims under California law. ${ }^{12}$

The aforementioned examples are not to suggest that the states stand in complete opposition to the Supreme Court-far from it. ${ }^{13}$ Instead, this Article identifies potential state responses to the apparent regression in federal court access, and it evaluates the extent to which state courts and public enforcers have engaged in these responses to date. If state courts and public enforcement are not the battlegrounds of the "litigation state,"14 they will be soon. These developments also connect with recent interest in the states as counterweights to a unified federal government after the 2016 election. ${ }^{15}$

8. See infra Part II.B.

9. See infra Part II.C.

10. See infra notes 313-314 and accompanying text.

11. See infra Part III.B.

12. See infra notes $352-356$ and accompanying text. In note 295 , I explain why I label this private suit as "public enforcement."

13. This also does not suggest that state courts and public enforcers can replace everything lost to the Supreme Court's procedural decisions. See infra Parts II.E, III.F \& IV.B.

14. See Sean Farhang, The litigation State: Public Regulation and Private LAWSUITS IN THE U. S. (2010).

15. See, e.g., Vivian Yee, To Combat Trump, Democrats Ready a G.O.P. Tactic: Lawsuits, N.Y. TIMES (Dec. 14, 2016), https://nyti.ms/2hPAdI3 [https://perma.cc/CT59-QTVJ]; $c f$. David J. Barron, Foreword: Blue State Federalism at the Crossroads, 3 HARV. L. \& POL'Y REV. 1 (2009) (discussing liberal interest in states during the George W. Bush administration); Robert A. Schapiro, Not Old or Borrowed: The Truly New Blue Federalism, 3 HARV. L. \& POL'Y REV. 33 (2009) (same). 
This Article thus aims to reorient the conversation away from an exclusive focus on federal procedure and toward other avenues for access to justice and private enforcement. While this approach departs from a federal court focus, it is consistent with two other themes in the literature. First, this Article takes seriously the emphasis on public, precedential court adjudication. ${ }^{16}$ The alternatives discussed below are court-based. Second, this Article takes seriously the central role of litigation in the American regulatory state. ${ }^{17}$ The discussion here addresses the enforcement of public and private laws alike.

In so doing, this study pursues a series of interrelated goals. Proponents of court access and private enforcement, and their allies in the states, might see in this Article a roadmap for further interventions if they feel stymied by the federal courts. Their opponents, too, might follow the same map to locate future confrontations. Thus, these procedural developments raise the stakes for state courts and state enforcement. ${ }^{18}$ My effort to identify potential responses outside of the federal courts also provides a baseline against which we can evaluate judicial and political actors: is the Roberts Court an outlier, or are its views consistent with a broader plaintiphobia? ${ }^{19}$ Even when the Court lacks de jure authority, do its decisions have de facto sway?

While this review surfaces opportunities for state courts and state enforcement, it also highlights their formal and functional limits-and it connects those opportunities and limits to procedural politics. ${ }^{20}$ Only a careful study of the Supreme Court's procedural jurisprudence reveals where doctrinal limits end and practical limits begin. Or, to put it another way, sometimes it is the Supreme Court that impairs court access and private enforcement, but other times the problems come from resource constraints, preemption, or politics. More generally, thinking clearly about the potential role for states raises questions about the political economy of procedural federalism-and, as explained below, such shifts to state courts and state enforcement may come with unintended risks.

Filling out this analysis, Part I of this Article briefly describes the major procedural decisions of the Roberts Court. Part II documents state court responses to those decisions, and Part III explores state public enforcement. Many of these areas have been unexplored by scholars, and this Article is the first to pull them together in one place. Based on these inquiries, Part IV offers

16. See, e.g., Judith Resnik, Diffusing Disputes: The Public in the Private of Arbitration, the Private in Courts, and the Erasure of Rights, 124 YALE L.J. 2804 (2015).

17. See, e.g., FARHANG, supra note 14; Burbank et al., supra note 4.

18. See, e.g., infra Part IV.B (discussing selection of state judges and executive enforcers).

19. Burbank and Farhang suggest that Supreme Court hostility toward private enforcement has not tracked the public mood. STEPHEN B. BURBANK \& SEAN FARHANG, RIGHTS AND RETRENCHMENT: THE COUNTERREVOLUTION AGAINST FEDERAL LITIGATION 192-214 (2017).

20. Cf. Burt Neuborne, The Myth of Parity, 90 HARV. L. REV. 1105 (1977) (assessing state and federal courts in an earlier era). 
some conclusions in light of the values of federalism and the politics of procedure.

In short, this Article calls for new attention on state court and publicenforcement responses to federal procedural retrenchment. Such responses are multifarious and have the potential to be effective. But this Article also illuminates serious challenges facing those efforts, and it suggests reasons to be cautious about the politics of state procedure and enforcement.

I.

\section{PROCEDURAL RETRENCHMENT IN THE ROBERTS COURT}

A central theme of this Article is that analyses of the Supreme Court's civil procedure decisions have been too focused on the federal courts, to the exclusion of state courts and public enforcement. Before exploring that claim further, it is helpful to review the decisions at the core of this critique. Many of these decisions are widely known, so this Section only briefly surveys the major civil procedure decisions of the Roberts Court ${ }^{21}$ and offers a sample of the criticism these decisions have engendered.

Pleading. To lawyers and law students, the most well-known procedural decisions of the Roberts Court are Bell Atlantic v. Twombly ${ }^{22}$ and Ashcroft v. Iqbal. ${ }^{23}$ Prior to 2007 , the federal courts employed a system of "notice pleading" under which plaintiffs were required to plead only enough facts to put defendants on notice of the claims against them. ${ }^{24}$ Twombly and Iqbal reoriented federal pleading around "plausibility." Plaintiffs are now required to plead facts that show a "plausible" claim and a "reasonable" possibility of success. ${ }^{25}$

This is not the place to adjudicate the intense empirical debate about the effects of Twombly and Iqbal, ${ }^{26}$ but two facts seem clear. First, Twombly and Iqbal announced a change as a matter of doctrine ${ }^{27}$ Second, this doctrinal change precipitated substantial criticism, particularly from those focused on private enforcement and access to justice. Scholars have referred to these decisions as "attacks on American democracy," 28 "subversions of law to achieve the

21. One issue not addressed here is statutory preemption of state substantive law. I exclude those decisions as "substantive," though they have significant consequences for jurisdiction and court access. Cf. infra Part II.E (discussing subject-matter jurisdiction and removal).

22. 550 U.S. 544 (2007).

23. 556 U.S. 662 (2009).

24. See FED. R. CIV. P. 8; Conley v. Gibson, 355 U.S. 41 (1957).

25. Iqbal, 556 U.S. at 678; Twombly, 550 U.S. at 556.

26. See generally David Freeman Engstrom, The Twiqbal Puzzle and Empirical Study of Civil Procedure, 65 StAN. L. REV. 1203 (2013) (collecting empirical sources); Jonah B. Gelbach, Material Facts in the Debate over Twombly and Iqbal, 68 STAN. L. REV. 369 (2016) (same).

27. See, e.g., Kevin M. Clermont, Three Myths About Twombly-Iqbal, 45 WAKE FOREST L. REV. 1337, 1371 (2010) ("The change in pleading, unless somehow undone, represents a truly major development in modern procedure.").

28. Steven B. Burbank \& Stephen N. Subrin, Litigation and Democracy: Restoring a Realistic Prospect of Trial, 46 HARV. C.R.-C.L. L. REV. 399, 405 (2011). 
restrictive ends of societal elites," 29 "threaten[ing] to undermine civil rights enforcement, compromise court access, and incentivize unethical conduct," and "mark[ing] a continued retreat from the principles of citizen access, private enforcement of public policies, and equality of litigant treatment in favor of corporate interests and concentrated wealth." ${ }^{31}$ One scholar chose Iqbal for a symposium entitled "The Worst Supreme Court Case Ever?"32 I could go on. ${ }^{33}$

Summary Judgment. To the extent that Twombly and Iqbal have a parallel in summary judgment, it would be the Rehnquist Court's decisions in the Celotex trilogy. ${ }^{34}$ Like Twombly and Iqbal, the Celotex trilogy made the law friendlier to pretrial disposition and provoked backlash among commentators. ${ }^{35}$ The Roberts Court has engaged with summary judgment as well. Although known primarily for its treatment of video evidence, Scott v. Harris may have consequences for the law of summary judgment. ${ }^{36}$ The Supreme Court explained in Scott that the non-moving party is not entitled to traditional summary judgment deference if its position "blatantly contradicts" the record. ${ }^{37}$ Professor Wolff has explained that this language represents a change in the prevailing federal standard with the potential to "erode the pathway to trial for plaintiffs in every type of dispute." 38

29. A. Benjamin Spencer, Iqbal and the Slide Toward Restrictive Procedure, 14 LEWIS \& CLARK L. REV. 185, 201 (2010).

30. Suzette M. Malveaux, Front Loading and Heavy Lifting: How Pre-Dismissal Discovery Can Address the Detrimental Effect of Iqbal on Civil Rights Cases, 14 LEWIS \& CLARK L. REV. 65, 65 (2010).

31. Arthur R. Miller, From Conley to Twombly to Iqbal: A Double Play on the Federal Rules of Civil Procedure, 60 DuKE L.J. 1, 10 (2010).

32. Steve Subrin, Ashcroft v. Iqbal: Contempt for Rules, Statutes, the Constitution, and Elemental Fairness, 12 NEV. L.J. 571, 573 (2012) (appearing in a symposium titled "The Worst Supreme Court Case Ever?"). Professor Subrin's essay began: “Ashcroft v. Iqbal is an embarrassment to the American Judicial System in which a majority of the Supreme Court chose to reject the rule of law." Id. at 571 (footnote omitted).

33. See, e.g., Dawinder S. Sidhu, First Korematsu and Now Ashcroft v. Iqbal: The Latest Chapter in the Wartime Supreme Court's Disregard for Claims of Discrimination, 58 BuFf. L. REV. 419 (2010).

34. Celotex Corp. v. Catrett, 477 U.S. 317 (1986); Anderson v. Liberty Lobby, Inc., 477 U.S. 242 (1986); Matsushita Elec. Indus. Co. v. Zenith Radio Corp., 475 U.S. 574 (1986). Celotex lowered the burden of production on the moving party and increased the burden on the non-movant.

35. See, e.g., Samuel Issacharoff \& George Loewenstein, Second Thoughts About Summary Judgment, 100 YALE L.J. 73 (1990); Arthur R. Miller, The Pretrial Rush to Judgment: Are the "Litigation Explosion," "Liability Crisis," and Efficiency Clichés Eroding Our Day in Court and Jury Trial Commitments?, 78 N.Y.U. L. REV. 982 (2003); Edward A. Purcell, Jr., From the Particular to the General: Three Federal Rules and the Jurisprudence of the Rehnquist and Roberts Courts, 162 U. PA. L. REV. 1731 (2014); Martin H. Redish, Summary Judgment and the Vanishing Trial: Implications of the Litigation Matrix, 57 STAN. L. REV. 1329 (2005).

36. 550 U.S. 372 (2007).

37. Id. at 372 .

38. Tobias Barrington Wolff, Scott v. Harris and the Future of Summary Judgment, 15 NEV. L.J. 1351, 1354 (2015). Wolff added that Scott "appears to erase the presumption in favor of non-moving parties altogether." $I d$. at 1352. 
The effects of Scott are seemingly less severe than Twombly and Iqbal. ${ }^{39}$ But at least according to Wolff, "the parallels are ominous."

Class Actions. The Supreme Court has also retrenched in class action law. ${ }^{41}$ Though perhaps properly understood as a Title VII decision, the Roberts Court's best-known class action ruling came in Wal-Mart v. Dukes. ${ }^{42}$ The Dukes majority required that a putative class establish the capacity to generate "common answers," not just "common questions." 43 The decision raised the evidentiary burden on plaintiffs to affirmatively establish this commonality, demanding "convincing" facts where they were not demanded before. ${ }^{44}$ Two years later, the Roberts Court called for a similar "rigorous analysis" of Rule 23's predominance requirement in Comcast Corporation. v. Behrend. ${ }^{45}$

Criticism of Dukes and Behrend has been widespread as well. ${ }^{46}$ Class actions have facilitated access to justice and private enforcement, especially for low-value claims. ${ }^{47}$ In this light, scholars have explained that Dukes limits "access to courts" and creates "new impediments" to private enforcement; ${ }^{48}$ "compromises employees' access to justice"; 49 "undermines the rights of workplace discrimination victims"; ${ }^{50}$ and demonstrates "the Court's willingness of late to place policy above principle in ways that restrict access to justice."

39. Compare id. at 1365-67 (collecting federal cases applying Scott), with supra notes 22-33 (discussing Twombly and Iqbal).

40. Wolff, supra note 38, at 1385.

41. I will treat separately class action decisions regarding arbitration, although those decisions have consequences for class actions as well. See, e.g., Am. Express Co. v. Italian Colors Rest., $133 \mathrm{~S}$. Ct. 2304, 2320 (2013) (Kagan, J., dissenting) ("To a hammer, everything looks like a nail. And to a Court bent on diminishing the usefulness of Rule 23, everything looks like a class action, ready to be dismantled."). Another class action case, Shady Grove Orthopedic Assocs., P.A. v. Allstate Ins. Co., 559 U.S. 393 (2010), is better understood as an Erie decision, thus it does not fit perfectly in this analysis. See Italian Colors, 133 S. Ct. 2304, 2320 (Kagan, J., dissenting) (holding that Rule 23 determines the requirements of a state law class action in federal court despite conflicting state law); Erie R.R. v. Tompkins, 304 U.S. 64 (1938); see also Stephen B. Burbank \& Tobias Barrington Wolff, Redeeming the Missed Opportunities of Shady Grove, 159 U. PA. L. REV. 17 (2010).

42. 564 U.S. $338(2011)$.

43. Id. at 350. I focus here on Dukes's effect on "commonality." See FED. R. CIV. P. 23(a)(2).

44. Dukes, 564 U.S. at 359.

45. 133 S. Ct. 1426, 1432 (2013).

46. See, e.g., Natalie Bucciarelli Pedersen, The Hazards of Dukes: The Substantive Consequences of a Procedural Decision, 44 U. TOL. L. REV. 123 (2012) (collecting sources).

47. See generally Burbank et al., supra note 4 (discussing private enforcement and connecting it to, inter alia, class actions).

48. Judith Resnik, Fairness in Numbers: A Comment on AT\&T v. Concepcion, Wal-Mart v. Dukes, and Turner v. Rogers, 125 HARV. L. REV. 78, 153 (2011).

49. Suzette M. Malveaux, How Goliath Won: The Future Implications of Dukes v. Wal-Mart, 106 Nw. U. L. REV. COLLOQUY 34, 37 (2011).

50. Joseph A. Seiner, Weathering Wal-Mart, 89 NOTRE DAME L. REV. 1343, 1344 (2014).

51. A. Benjamin Spencer, Class Actions, Heightened Commonality, and Declining Access to Justice, 93 B.U. L. REV. 441, 445 (2013). 
Arbitration. The rise of arbitration predates the Roberts Court, ${ }^{52}$ but the Roberts Court has been particularly aggressive in promoting it ${ }^{53}$ : allocating more issues to arbitrators and fewer to courts; ${ }^{54}$ preempting state laws that create obstacles to arbitration; ${ }^{55}$ and limiting exceptions designed to ensure the effective vindication of substantive rights. ${ }^{56}$ The Roberts Court's arbitration decisions have been particularly hostile to aggregate dispute resolution. $A T \& T v$. Concepcion held that the Federal Arbitration Act (FAA) preempted a state law that treated certain class action waivers as unconscionable. ${ }^{57}$ American Express v. Italian Colors later refused to invalidate an arbitration agreement with a classarbitration waiver even if class resolution was the only economically viable way to "effective[ly] vindicat[e]" a federal right. ${ }^{58}$

Here again, criticism has been sharp. Dissenting from Italian Colors, Justice Kagan remarked that "[i]n the hands of today's majority, arbitration threatens to become . . . a mechanism easily made to block the vindication of meritorious federal claims and insulate wrongdoers from liability." 59 Scholars have been similarly critical. Judith Resnik observed that the Court's arbitration jurisprudence "strips individuals of access to courts to enforce state and federal rights, strips the public of its rights of audience to observe state-empowered decision makers imposing legally binding decisions, and strips the courts of their obligation to respond to alleged injuries." ${ }^{, 60}$ Other scholars have explained that Concepcion and Italian Colors "operate to dismantle entire fields of law, including laws against fraud, deception, predatory conduct, antitrust violations, and employment discrimination," ${ }^{61}$ and they "erode substantive law from the

52. See, e.g., Resnik, Diffusing Disputes, supra note 16.

53. See, e.g., Jeffrey W. Stempel, Tainted Love: An Increasingly Odd Arbitral Infatuation in Derogation of Sound and Consistent Jurisprudence, 60 U. KAN. L. REV. 795, 852 (2012) ("[T]he Roberts Court ... produced more infatuatedly and dramatically divisive pro-arbitration opinions restricting class action litigation and even class action arbitration.").

54. E.g., Rent-A-Center, W., Inc. v. Jackson, 561 U.S. 63 (2010); Buckeye Check Cashing, Inc. v. Cardegna, 546 U.S. 440 (2006).

55. E.g., DIRECTV, Inc. v. Imburgia, 136 S. Ct. 463 (2015) (rejecting state court contract interpretation that revived the rule preempted in Concepcion); AT\&T Mobility LLC v. Concepcion, 563 U.S. 333 (2011) (preempting California rule that invalidated as unconscionable certain consumer contracts of adhesion containing class-arbitration waivers); Preston v. Ferrer, 552 U.S. 346, 363 (2008) (preempting administrative-exhaustion requirement).

56. E.g., Am. Express Co. v. Italian Colors Rest., 133 S. Ct. 2304 (2013) (refusing to invalidate arbitration agreement prohibiting class arbitration). Stolt-Nielsen S.A. v. AnimalFeeds International further held that an arbitrator could not unilaterally impose class procedures without affirmative consent of the parties. 559 U.S. 662 (2010).

57. 563 U.S. at 333

58. 133 S. Ct. at 2317.

59. 133 S. Ct. at 2320 (Kagan, J., dissenting).

60. Resnik, Diffusing Disputes, supra note 16, at 2811.

61. Christopher R. Leslie, The Arbitration Bootstrap, 94 TEX. L. REV. 265, 268 (2015). 
books, with the consequent erosion of both the private compensatory goals and public deterrent objectives of that law."

Standing. Although standing doctrine in recent years has "fragmented," 63 with respect to private disputes ${ }^{64}$ the Roberts Court's main contribution has been to limit Congress's ability to confer Article III standing on litigants. ${ }^{65}$ In a measured opinion, Spokeo v. Robins reaffirmed that "Congress cannot erase Article III's standing requirements by statutorily granting the right to sue to a plaintiff who would not otherwise have standing." ${ }^{.66}$ In particular, the Court explained that Congress could not provide standing for a "bare procedural violation" or a deprivation that is not sufficiently "concrete." ${ }^{, 67}$ Whatever these phrases mean, the result cannot be that "a plaintiff automatically satisfies the injury-in-fact requirement whenever a statute grants a person a statutory right and purports to authorize that person to sue to vindicate that right." 68

Leading up to Spokeo, one critic asked "whether the conservative wing of the Roberts Court will respect our Constitution's guarantee of access to courts or subvert it, leaving Americans without legal recourse when corporations violate federal rights." ${ }^{\circ 9}$ Reveling in its less-devastating-than-expected outcome, another wrote that Spokeo "was supposed to be one of those cases that lets the Supreme Court's conservatives gut class action rules without most people noticing." ${ }^{, 70}$ And still, critics have worried that Spokeo's contribution to standing

62. J. Maria Glover, Disappearing Claims and the Erosion of Substantive Law, 124 YALE L.J. 3052, 3054 (2015)

63. See generally Richard H. Fallon, Jr., The Fragmentation of Standing, 93 TEX. L. REV. 1061 (2015) (arguing standing doctrine has become inconsistent and anomalous based on recent precedent).

64. By private disputes, I mean to exclude suits by or against government actors, such as decisions on national security, the First Amendment, and equal protection. See id. at 1071-89 (collecting cases).

65. See, e.g., Summers v. Earth Island Inst., 555 U.S. 488, 497 (2009) (“[T]he requirement of injury in fact is a hard floor of Article III jurisdiction that cannot be removed by statute."). As explained below, although this message addresses Congress, it is best viewed as a limit on federal courts. See infra notes 219-227 and accompanying text; see also Zachary D. Clopton, Justiciability, Federalism, and the Administrative State, 103 CORNELL L. REV. (forthcoming 2018) (elaborating on this interpretation and its consequences for policymaking).

66. Spokeo, Inc. v. Robins, 136 S. Ct. 1540, 1547-48 (2016) (quoting Raines v. Byrd, 521 U.S. 811, 820 n.3 (1997)); see also id. at 1548 (quoting Gladstone, Realtors v. Village of Bellwood, 441 U.S. 91, 100 (1979)) ("In no event . . may Congress abrogate the Art. III minima ....").

67. Spokeo, 136 S. Ct. at 1549.

68. Id. The Court seems more willing to find Congress-created standing when a state is bringing suit. See, e.g., Massachusetts v. EPA, 549 U.S. 497 (2007); see also Fallon, supra note 63.

69. David Gans, No Day in Court: Big Business's Attack on Access to Courts, BALKINIZATION (Oct. 9, 2015), http://balkin.blogspot.com/2015/10/no-day-in-court-big-businesss-attack-on.html [https://perma.cc/X2DB-GB2G].

70. Mark Joseph Stern, SCOTUS Misses an Opportunity to Gut Class Actions and Consumer $\begin{array}{llllll}\text { Privacy Laws, } & \text { SLATE } & \text { (May 16, 2016, } & \text { 12:56 } & \text { PM), }\end{array}$ http://www.slate.com/blogs/the_slatest/2016/05/16/spokeo_v_robins_spares_class_actions_and_consu mer_privacy.html [https://perma.cc/4MDQ-S7V4]. 
law "seems to be serving no purpose other than to constitutionalize a deregulatory agenda.",

More generally, critics have argued that the Supreme Court's standing doctrine represents "an insupportable judicial contraction of the legislative power," 72 and that it "mak[es] it more difficult to implement federal laws." Standing doctrine is a particular barrier to private enforcement, ${ }^{74}$ as critics have argued that its current incarnation "effectively preclude[s] Congress from pushing private enforcement of public law to its outermost limits." 75 For its part, the Roberts Court seems to treat these criticisms as consistent with its goals. Speaking for the Court, Justice Kennedy remarked that "[i]n an era of frequent litigation, class actions, sweeping injunctions with prospective effect, and continuing jurisdiction to enforce judicial remedies, courts must be more careful to insist on the formal rules of standing, not less so." ${ }^{, 76}$

Personal Jurisdiction. The Roberts Court also has taken up constitutional limits on personal jurisdiction. In Goodyear Dunlop Tires v. Brown ${ }^{77}$ and Daimler v. Bauman ${ }^{78}$ the Court reined in some lower court decisions that stretched "general jurisdiction" to non-home-state corporations. ${ }^{79}$ The Court also held tight to limits on "specific jurisdiction." In J. McIntyre v. Nicastro, a divided Court held that New Jersey could not assert personal jurisdiction over a foreign manufacturer of a machine that harmed a New Jersey resident. ${ }^{80}$ And most recently in Bristol-Myers Squibb v. Superior Court, the Court rejected California jurisdiction over claims by noncitizens against an out-of-state drug company, and in so doing, seemingly altered the theoretical basis of specific jurisdictionif not more. ${ }^{81}$

71. Felix T. Wu, How Privacy Distorted Standing Law, 66 DePaUl L. ReV. 439, 440 (2017).

72. Richard J. Pierce, Jr., Lujan v. Defenders of Wildlife: Standing as a Judicially Imposed Limit on Legislative Power, 42 DUKE L.J. 1170, 1170-71 (1993). (2005).

73. Robert A. Schapiro, Toward a Theory of Interactive Federalism, 91 IOWA L. REV. 243, 303

74. See, e.g., Stephen B. Burbank \& Sean Farhang, Litigation Reform: An Institutional Approach, 162 U. PA. L. REV. 1543 (2014).

75. Amanda M. Rose, Reforming Securities Litigation Reform: Restructuring the Relationship Between Public and Private Enforcement of Rule 10b-5, 108 COLUM. L. REV. 1301, 1316 (2008).

76. Ariz. Christian Sch. Tuition Org. v. Winn, 563 U.S. 125, 146 (2011).

77. 564 U.S. 915 (2011).

78. 134 S. Ct. $746(2014)$.

79. See Goodyear, 564 U.S. at 926-29 (defining the limited scope of general jurisdiction); Daimler, 134 S. Ct. at 756-58 (same). See generally Arthur T. von Mehren \& Donald T. Trautman, Jurisdiction to Adjudicate: A Suggested Analysis, 79 HARV. L. REV. 1121 (1966) (delineating general versus specific jurisdiction).

80. 564 U.S. 873 (2011); see also Walden v. Fiore, 134 S. Ct. 1115 (2014) (articulating further limits on specific jurisdiction).

81. 137 S. Ct. 1773 (2017) (emphasizing the "sovereignty" rationale for personal jurisdiction). See Andrew D. Bradt \& D. Theodore Rave, Aggregation on Defendants' Terms: Bristol-Myers Squibb and the Federalization of Mass-Tort Litigation, 59 B.C. L. REV. (forthcoming 2018) (manuscript at 6 \& n.13). 
Commenters have noted that the aforementioned general-jurisdiction decisions reflect the Court's "restrictive ethos." ${ }^{, 82}$ Similarly, they claim that the specific-jurisdiction decisions "[1]imit [c]onsumers' [a]ccess to [j]udicial $[\mathrm{r}]$ emedies" $" 83$ and represent "yet another procedural stop sign, one posted at the very genesis of the case." ${ }^{, 4}$ More generally, critics of personal jurisdiction law have worried that these cases "provide[] a blueprint" for foreign corporations to avoid US courts. ${ }^{85}$

International Law Cases. Although some of the aforementioned decisions have consequences for international litigation, ${ }^{86}$ I want to address separately those decisions that focus on international law claims. ${ }^{87}$ First, in Kiobel v. Royal Dutch Petroleum ${ }^{88}$ the Supreme Court limited the scope of the Alien Tort Statute $(\mathrm{ATS})^{89}$ to cases that "touch and concern the territory of the United States.",90 Second, in a series of decisions regarding the Vienna Convention on Consular Relations, ${ }^{91}$ the Supreme Court held - contrary to the International Court of Justice $^{92}$ - that Vienna Convention claims raised in habeas proceedings are subject to state procedural default rules. ${ }^{93}$

These cases too were criticized for keeping deserving plaintiffs out of court. ${ }^{94}$ Scholars have noted that "Kiobel presents a barrier to those seeking access to judicial remedies for businesses' involvement in human rights abuses outside the United States," $"$ and now "parties with claims implicating

82. Donald Earl Childress III, Escaping Federal Law in Transnational Cases: The Brave New World of Transnational Litigation, 93 N.C. L. REV. 995, 999 (2015).

83. Greg Saetrum, Righting the Ship: Implications of J. McIntyre v. Nicastro and How to Navigate the Stream of Commerce in its Wake, 55 ARIZ. L. REV. 499, 522 (2013).

84. Arthur R. Miller, Simplified Pleading, Meaningful Days in Court, and Trials on the Merits: Reflections on the Deformation of Federal Procedure, 88 N.Y.U. L. REV. 286, 352 (2013).

85. Michael Vitiello, Limiting Access to U.S. Courts: The Supreme Court's New Personal Jurisdiction Case Law, 21 U.C. DAVIS J. INT'L L. \& POL'Y 209, 212 (2015).

86. See, e.g., Daimler AG v. Bauman, 134 S. Ct. 746 (2014).

87. The Roberts Court has also evinced hostility towards international claims based on US law. See, e.g., Morrison v. Nat'l Austl. Bank Ltd., 561 U.S. 247 (2010) (applying a restrictive presumption against extraterritoriality to federal statutes). See generally Zachary D. Clopton, Replacing the Presumption Against Extraterritoriality, 94 B.U. L. REV. 1 (2014) (discussing recent decisions on extraterritoriality and arguing against the current approach).

88. 569 U.S. $108(2013)$

89. 28 U.S.C. $\S 1350$ (2012).

90. Kiobel, 569 U.S. at 125.

91. Garcia v. Texas, 564 U.S. 940 (2011) (discussing the Vienna Convention on Consular Relations, Apr. 24, 1963, 21 U.S.T. 77, 596 U.N.T.S. 261); Medellin v. Texas, 554 U.S. 759 (2008) (same); Medellin v. Texas, 552 U.S. 491 (2008) (same); Sanchez-Llamas v. Oregon, 548 U.S. 331 (2006) (same); Breard v. Greene, 523 U.S. 371 (1998) (per curiam) (same).

92. Case Concerning Avena and Other Mexican Nationals (Mex. v. U.S.), Judgment, 2004 I.C.J. 12 (Mar. 31) (holding that the United States breached its obligations under the Convention).

93. See Breard, 523 U.S. at 375-76; Medellin, 552 U.S. at 517.

94. In other words, "U.S. courts have pursued a studied avoidance of transnational litigation." Pamela K. Bookman, Litigation Isolationism, 67 STAN. L. REV. 1081, 1081 (2015).

95. Gwynne L. Skinner, Beyond Kiobel: Providing Access to Judicial Remedies for Violations of International Human Rights Norms by Transnational Business in a New (Post-Kiobel) World, 46 COLUM. HuM. RTS. L. REV. 158, 198 (2014). 
international law will have more difficulty gaining access to domestic United States courts to litigate." ${ }^{96}$

Summary. Returning to Dean Chemerinsky's observation, it appears to many commentators that the Roberts Court is "systematically closing the courthouse doors." $" 97$ This claim applies to each of the topics addressed here: pleading; summary judgment; class actions; arbitration; standing; personal jurisdiction; and international law. In most of these areas, this claim is probably accurate. Scholars have correctly identified ways that these procedural doctrines impede court access and private enforcement - at least within the federal courts. ${ }^{98}$ When we account for state courts and public suits, however, the story becomes more complex.

II.

\section{Civil Procedure in State Courts}

In a 1977 article for the Harvard Law Review, Justice William Brennan argued that state courts should use state constitutions to protect individual rights where the Burger Court had cut them back. ${ }^{99}$ Though the record was mixed, some state courts took Justice Brennan up on this suggestion. ${ }^{100}$

Although I do not endorse this strategy with the vigor of Justice Brennan, this Section observes that state courts similarly have the authority to use state law to deviate from the Roberts Court's approach to civil procedure. ${ }^{101}$ This Section teases out these doctrinal pathways and examines the extent to which state courts have taken advantage of such opportunities to date. Regardless of whether these opportunities are welcome, this Section shows that dismayed advocates of private enforcement and court access may find receptive audiences if they look outside of the federal courts.

96. Laura E. Little, Empowerment Through Restraint: Reverse Preemption or Hybrid Lawmaking?, 59 CASE W. RES. L. REV. 955, 967 (2009).

97. Chemerinsky, supra note 3.

98. Cf. infra Parts II-III (observing alternatives to federal procedure).

99. William J. Brennan, Jr., State Constitutions and the Protection of Individual Rights, 90 HARV. L. REV. 489 (1977); see also William J. Brennan, Jr., The Bill of Rights and the States: The Revival of State Constitutions as Guardians of Individual Rights, 61 N.Y.U. L. REV. 535 (1986). For a discussion of state courts and federal statutory interpretation, see generally Amanda Frost, Inferiority Complex: Should State Courts Follow Lower Federal Court Precedent on the Meaning of Federal Law?, 68 VAND. L. REV. 53 (2015).

100. See, e.g., James A. Gardner, The Failed Discourse of State Constitutionalism, 90 MiCH. L. REV. 761 (1992) (collecting sources and criticizing the project).

101. State procedural deviation from the Supreme Court is not limited to the Roberts Court. See, e.g., 8 Alan Wright \& ARTHUR R. Miller, Federal PRACTICE AND Procedure: Civil $\S 2022$ (3d ed. 2017 Update) (discussing state deviation from Hickman v. Taylor, 329 U.S. 495 (1947), on attorney work product); Zachary D. Clopton, Making State Civil Procedure (in progress) (on file with author). 


\section{A. Federal Rules in State Courts}

One major category of Supreme Court decisions arises out of the Federal Rules of Civil Procedure. Stephen Burbank and Sean Farhang have argued that the Supreme Court is the primary locus for ideological retrenchment against private enforcement of federal claims. ${ }^{102}$ Theodore Eisenberg and Kevin Clermont found "plaintiphobia" in Supreme Court decisional law. ${ }^{103}$ These authors, and many others, have emphasized the pernicious consequences of the Supreme Court's interpretations of the Federal Rules. ${ }^{104}$

This Section begins with an unexceptional claim: the Federal Rules of Civil Procedure are federal rules of civil procedure. ${ }^{105}$ They do not apply directly in state courts, ${ }^{106}$ and they cannot under current law. ${ }^{107}$ States thus remain free to reject Supreme Court decisions interpreting federal procedural rules, even if state rules are patterned on the federal ones. ${ }^{108}$ This Section explores whether states have deviated from federal rules with respect to pleading, summary judgment, and class actions.

\section{Pleading}

Given their salience, I begin with Twombly and Iqbal. Although many investigations into pleading regimes divide the world into "fact pleading" and

102. BURBANK \& FARHANG, supra note 19, at 3. Burbank and Farhang emphasized that this effect is driven by the jurisprudence of the Supreme Court, rather than its rulemaking. Id.

103. Eisenberg \& Clermont, supra note 5.

104. See supra notes $28-33,35,38,46-51$ (citing sources). This is not to suggest that these authors find the Federal Rules to be the exclusive source of such retrenchment. See, e.g., BURBANK \& FARHANG, supra note 19, at 144-45 (referring to decisions about standing, private rights of action, attorney's fees, damages, and arbitration).

105. FED. R. CIV. P. 1 ("These rules govern the procedure in all civil actions and proceedings in the United States district courts ....").

106. Even in so-called "Reverse Erie" cases, state courts applying federal procedural doctrines to federally created rights are not applying the Federal Rules of their own force. See, e.g., STEVEN H. SteINGLASS, SECTION 1983 LitigATION IN STATE COURTS $§ 12.7$ (2016) (collecting examples of states mirroring and not mirroring federal pleading standards for Section 1983 claims in state courts).

107. See 28 U.S.C. $\$ 2072$ (2012) (Rules Enabling Act).

108. There is considerable difficulty in measuring the degree of overlap between federal and state systems of procedure. The prevailing view seems to be that the Federal Rules had a marked impact on the form of state procedure (rules versus code), and that they initially had a strong impact on content, though that trend has slowed, if not reversed. See, e.g., Thomas O. Main, Procedural Uniformity and the Exaggerated Role of Rules: A Survey of Intra-State Uniformity in Three States That Have Not Adopted the Federal Rules of Civil Procedure, 46 VILL. L. REV. 311 (2001); John B. Oakley, A Fresh Look at the Federal Rules in State Courts, 3 NEV. L.J. 354 (2003); John B. Oakley \& Arthur F. Coon, The Federal Rules in State Courts: A Survey of State Court Systems of Civil Procedure, 61 WASH. L. REV. 1367 (1986). This paper contributes to this inquiry by examining not the role of the Federal Rules per se, but the role of the Supreme Court's changing interpretation of those rules. $C f$. Stephen N. Subrin \& Thomas O. Main, Braking the Rules: Why State Courts Should Not Replicate Amendments to the Federal Rules of Civil Procedure, 67 CASE W. RES. L. REV. 501 (2016) (discussing whether state rulemakers should track federal rule amendments). 
"notice pleading" jurisdictions, ${ }^{109}$ the effect of Twombly and Iqbal is more nuanced. Under the new regime, in order to defeat a motion to dismiss, the plaintiff must establish the "plausibility" of an entitlement to relief in federal court. ${ }^{110}$

Because plausibility pleading is (supposedly) grounded in Federal Rule of Civil Procedure 8, the Supreme Court has not required it for state courts. And although some states have voluntarily adopted this standard, ${ }^{111}$ courts in nineteen states have expressly rejected plausibility pleading: Alabama; ${ }^{12}$ Arizona; ${ }^{113}$ Delaware; ${ }^{114}$ Georgia $;{ }^{115}$ Iowa; ${ }^{116}$ Kansas $;{ }^{117}$ Minnesota; ${ }^{118}$ Montana; $;{ }^{119}$ Nevada $;{ }^{120}$ New Mexico; ${ }^{121}$ New York; ${ }^{122}$ North Carolina $;{ }^{123}$ Ohio $;{ }^{124}$

109. See Jill Curry \& Matthew Ward, Are Twombly \& Iqbal Affecting Where Plaintiffs File? A Study Comparing Removal Rates by State, 45 TEX. TECH L. REV. 827 (2013) (classifying jurisdictions and collecting additional sources).

110. See supra notes 22-25, 27 and accompanying text; see also Clermont, supra note 27, at 1348-50 (suggesting "fact pleading" as a preferable alternative to "plausibility pleading").

111. See Warne v. Hall, 373 P.3d 588, 595 (Colo. 2016) (en banc); Edelman v. Laux, No. CV115005710, 2013 WL 4504793, at *20 (Conn. Super. Ct. July 26, 2013) (collecting cases); Potomac Dev. Corp. v. District of Columbia, 28 A.3d 531, 544 (D.C. Ct. App. 2011); Iannacchino v. Ford Motor Co., 888 N.E.2d 879, 890 (Mass. 2008); Doe v. Bd. of Regents of the Univ. of Neb., 788 N.W.2d 264, 278 (Neb. 2010), overruled on other grounds by Davis v. State, 902 N.W.2d 165 (2017); Sisney v. Best Inc., 754 N.W.2d 804, 809 (S.D. 2008); GoDaddy.com, LLC v. Toups, 429 S.W.3d 752, 754 (Tex. Ct. App. 2014); Data Key Partners v. Permira Advisers LLC, 849 N.W.2d 693, 699-701 (Wis. 2014); see also MYD Marine Distrib., Inc. v. Int'1 Paint Ltd., 76 So. 3d 42, 47 n.4 (Fla. Dist. Ct. App. 2011) (potentially limited to antitrust law). Maine uses Twombly for civil perjury claims. Bean v. Cummings, 939 A.2d 676, 680 (Me. 2008). And there is a split among courts in Ohio and Texas. See infra notes 124, 127. For further discussion of some of these decisions, see generally Scott Dodson, The Gravitational Force of Federal Law, 164 U. PA. L. REV. 703 (2016).

112. Thomas v. Williams, 21 So. 3d 1234, 1236 n.1 (Ala. Civ. App. 2008).

113. Cullen v. Auto-Owners Ins. Co., 189 P.3d 344, 345 (Ariz. 2008) (en banc).

114. Cent. Mortg. Co. v. Morgan Stanley Mortg. Capital Holdings LLC, 27 A.3d 531, 537 (Del. 2011).

115. Bush v. Bank of N.Y. Mellon, 720 S.E.2d 370, 375 n.13 (Ga. Ct. App. 2011).

116. Hawkeye Foodservice Distrib., Inc. v. Iowa Educators Corp., 812 N.W.2d 600, 608-09 (Iowa 2012).

117. Smith v. State, No. 104,775, 2012 WL 1072756, at*6 (Kan. Ct. App. Mar. 23, 2012).

118. Walsh v. U.S. Bank, N.A., 851 N.W.2d 598, 603 (Minn. 2014).

119. Brilz v. Metro. Gen. Ins. Co., 285 P.3d 494, 500 (Mont. 2012).

120. Garcia v. Prudential Ins. Co. of Am., 293 P.3d 869, 871 n.2 (Nev. 2013).

121. Madrid v. Vill. of Chama, 283 P.3d 871, 876 (N.M. Ct. App. 2012).

122. Krause v. Lancer \& Loader Grp. LLC, 965 N.Y.S.2d 312, 320 n.3 (N.Y. Sup. Ct. 2013).

123. Holleman v. Aiken, 668 S.E.2d 579, 584-85 (N.C. Ct. App. 2008).

124. There is a split in authority among Ohio's courts of appeals. See Tuleta v. Med. Mut. of Ohio, 6 N.E.3d 106, 113-14 (Ohio Ct. App. 8th Dist. 2014) (rejecting plausibility); Bahen v. Diocese of Steubenville, No. 11 JE 34, 2013 WL 2316640, at *3 (Ohio Ct. App. 7th Dist. May 24, 2013) (same); Sacksteder v. Senney, No. 24993, 2012 WL 4480695, at *9-11 (Ohio Ct. App. 2d Dist. Dec. 28, 2012) (same). But see Mohat v. Horvath, No. 2013-L-009, 2013 WL 5450296, at *2 (Ohio Ct. App. 11th Dist. Sept. 30, 2013) (accepting plausibility); Bumpus v. Ward, No. 2012-CA-5, 2012 WL 4789768, at *2 (Ohio Ct. App. 5th Dist. Oct. 9, 2012) (same). 
Oklahoma; ${ }^{125}$ Tennessee; ${ }^{126}$ Texas; ${ }^{127}$ Vermont; ${ }^{128}$ Washington; ${ }^{129}$ and West Virginia. ${ }^{130}$ For good measure, the local courts of Guam ${ }^{131}$ and the Northern Mariana Islands ${ }^{132}$ have rejected plausibility pleading too. ${ }^{133}$ Suits in these courts may survive a motion to dismiss even if they would not pass muster in federal court. For example, according to the Washington Supreme Court: "The Supreme Court's plausibility standard is predicated on policy determinations specific to the federal trial courts. ... Neither party has shown these policy determinations hold sufficiently true in the Washington trial courts to warrant such a drastic change in court procedure." 134 Indeed, multiple state courts have applied liberal state pleading standards to federal claims (such as Section 1983 claims) rather than testing them for plausibility. ${ }^{135}$

125. Edelen v. Bd. of Comm'rs, 266 P.3d 660, 663 (Okla. Civ. App. 2011).

126. Webb v. Nashville Area Habitat for Humanity, Inc., 346 S.W.3d 422, 425 (Tenn. 2011).

127. There is a split among Texas courts of appeals. See Reaves v. Corpus Christi, 518 S.W.3d 594, 612 (Tex. Ct. App. Corpus Christi-Edinburg 2017) (rejecting plausibility). But see GoDaddy.com, LLC v. Toups, 429 S.W.3d 752, 754 (Tex. Ct. App. Beaumont 2014) (accepting plausibility). After Twombly and Iqbal, the Texas Supreme Court characterized Texas as a "notice pleading" jurisdiction. See In re Lipsky, 460 S.W.3d 579, 590 (Tex. 2015).

128. Colby v. Umbrella, 955 A.2d 1082, 1086 n.1 (Vt. 2008).

129. McCurry v. Chevy Chase Bank, FSB, 233 P.3d 861, 863 (Wash. 2010) (en banc).

130. Roth v. DeFeliceCare, Inc., 700 S.E.2d 183, 189 n.4 (W. Va. 2010).

131. Ukau v. Wang, No. CVA15-008, 2016 WL 4582244, at*4 (Guam Aug. 31, 2016).

132. Syed v. Mobil Oil Mariana Islands, No. 090467, 2012 WL 6738436, at*4 (N. Mar. I. Dec. 31, 2012).

133. In addition to the cases cited in the prior notes, two Indiana cases have declined to apply Twombly and Iqbal. State v. Am. Family Voices, Inc., 898 N.E.2d 293, 296 n.1 (Ind. 2008); Droscha v. Shepherd, 931 N.E.2d 882, 887 n.1 (Ind. Ct. App. 2010). And two Missouri cases have implied a distinction between state pleading requirements and plausibility. Crest Constr. II, Inc. v. Hart, 487 S.W.3d 85, 90 (Mo. Ct. App. 2016); Jennings v. Bd. of Curators of Mo. State Univ., 386 S.W.3d 796, 799 n.4 (Mo. Ct. App. 2012).

134. McCurry v. Chevy Chase Bank, FSB, 233 P.3d 861, 863 (Wash. 2010) (en banc).

135. See, e.g., Davis v. Bay Cty. Jail, 155 So. 3d 1173, 1179 (Fla. Dist. Ct. App. 2014) (applying state pleading standard to Section 1983 claim); Landrith v. Jordan, No. 107,959, 2013 WL 5187269, at *10 (Kan. Ct. App. Sept. 13, 2013) (applying state pleading standard to Section 1983 claim); Thompson v. City of New York, 23 N.Y.S.3d 839, 856-57 (N.Y. Sup. Ct. 2015) (collecting New York cases applying state pleading standards to Section 1983 claims); Torres v. McCann, No. 13-15-00187-CV, 2016 WL 3225880, at*5 n.4 (Tex. Ct. App. June 30, 2016) (applying state pleading standard to Section 1983 claim); Peak Alarm Co., Inc. v. Salt Lake City Corp., 243 P.3d 1221, 1245 \& n.13 (Utah 2010) (applying state "notice pleading" standard to Section 1983 case after Twombly). Although courts in Delaware and California have applied federal pleading standards to Section 1983 cases, those states typically apply fact pleading. See, e.g., Golin v. Allenby, A140652, 2015 WL 5513224, at* 4 (Cal. Ct. App. 1st Dist. Sept. 18, 2015) (applying federal pleading standard to Section 1983 suit); Eskridge v. Hutchins, No. K16C-10-009 JJC, 2017 WL 1076726, at *3 (Del. Super. Ct. Mar. 22, 2017) (same). In other words, in Delaware and California, state pleading standards might be more restrictive, and the Supreme Court has been wary about states unduly restricting pleading in certain federal claims. See Brown v. W. Ry. Co. of Ala., 338 U.S. 294 (1949) (holding that state could not apply restrictive state pleading standards to FELA claim). 
Table A-State Pleading Standards ${ }^{136}$

\begin{tabular}{|ll|l|l|}
\hline \multicolumn{2}{|c|}{ Notice } & \multicolumn{1}{|c|}{ Fact } & \multicolumn{1}{|c|}{ Plausibility } \\
\hline Alabama* & New Jersey & Arkansas & Colorado \\
Alaska & New Mexico* & California & Dist. of Columbia \\
Arizona* & New York* & Connecticut & Massachusetts \\
Georgia* & North Carolina* & Delaware*137 & Nebraska \\
Hawai'i & North Dakota & Florida & South Dakota \\
Idaho & Ohio* & Illinois & Wisconsin \\
Indiana & Oklahoma* & Louisiana & \\
Iowa* & Rhode Island & Maryland & \\
Kansas* & Tennessee* & Missouri & \\
Kentucky & Texas* & Oregon & \\
Maine & Utah & Pennsylvania & \\
Michigan & Vermont* & South Carolina & \\
Minnesota* & Virginia & & \\
Mississippi & Washington* & & \\
Montana* & West Virginia* & & \\
Nevada* & Wyoming & & \\
New Hampshire & & & \\
& & & \\
*State court rejected plausibility & & \\
\hline
\end{tabular}

\section{Summary Judgment}

The effects of Scott $v$. Harris's approach to summary judgment in state courts are more difficult to discern. As explained above, Scott seemed to erase the typical summary judgment deference if plaintiff's position "blatantly contradicts" the record. ${ }^{138}$ Since Scott, many state courts addressing state law claims ${ }^{139}$ have interpreted their summary judgment rules to include a new

136. See infra Appendix 1 citing each state's standard and any responses to Twombly and Iqbal.

137. Delaware is challenging to classify. See Norton v. K-Sea Transp. Partners L.P., 67 A.3d 354, 360 (Del. 2013) (demanding pleading of facts); Winshall v. Viacom Int'l, Inc., 76 A.3d 808, 813 n.12 (Del. 2013) (applying a "conceivability" standard); Tekstrom, Inc. v. Savla, No. 464, 2006, 2007 WL 328836, at *5 (Del. 2007) (characterizing Delaware as a notice-pleading state); Fennell v. Hampton, No. 249, 2010, 2010 WL 4103011, at *2 (Del. 2010) (applying the "no set of facts" standard). Most studies treat Delaware as a fact-pleading state. See Curry \& Ward, supra note 109; Oakley, supra note 108; Oakley \& Coon, supra note 108.

138. See 550 U.S. 372, 380 (2007); see also supra notes 36-40 and accompanying text; Wolff, supra note 38, at 1353 (collecting federal cases and explaining that "developments in the lower federal courts reveal that the uncertainty introduced by the opinion is already eroding this core feature of the summary judgment standard").

139. For purposes of this study, I exclude federal claims in state court that might receive federal treatment based on preemption or "Reverse Erie." See Felder v. Casey, 487 U.S. 131 (1988) (requiring the state court to apply federal procedure to Section 1983 suit); see also Slowikowska v. San Diego 
category of "blatantly contradicting" versions of events. ${ }^{140}$ In other words, many state courts have followed Scott as persuasive authority. Though there are some cases in which state courts have found Scott inapposite, ${ }^{141}$ I was unable to locate any state court decisions expressly rejecting Scott's "blatantly contradicts" approach. ${ }^{142}$ I cannot rule out state courts implicitly rejecting $S c o t t,{ }^{143}$ but it is noteworthy that while many state courts have cited it approvingly, none has announced to litigants and future courts that it should not apply. ${ }^{144}$

Sheriff's Dep't, D066597, 2015 WL 7307867, at *6 (Cal. Ct. App. Nov. 20, 2015) (citing Scott for the "blatantly contradicts" test in a Section 1983 case in state court but not specifying whether it was applying federal or state procedure).

140. For cases articulating a "blatantly contradicts" test in state court on state law claims, see Carter v. City of New London Bd. of Educ., No. KNLCV146022709S, 2015 WL 7268504, at *5 (Conn. Super. Ct. Oct. 20, 2015); Council of Unit Owners of Windswept Condo. Ass'n v. Schumm, No. S12C08-011 RFS, 2013 WL 6133621, at *6 n.46 (Del. Super. Ct. Nov. 20, 2013); Smith v. Wal-Mart Stores E., LP, 765 S.E.2d 518, 524 (Ga. Ct. App. 2014); Porter v. Massarelli, 692 S.E.2d 722, 725 (Ga. Ct. App. 2010); Calhoun v. CSX Transp., Inc., 331 S.W.3d 236, 245 (Ky. 2011); Dyer v. Dep't of Transp., 951 A.2d 821, 827 n.6 (Me. 2008); Fuhr v. Trinity Health Corp., 837 N.W.2d 275 (Mich. 2013) (reversing and adopting the dissent from Fuhr v. Trinity Health Corp., No. 309877, 2013 WL 1629301, at *6 (Mich. Ct. App. Apr. 16, 2013)); Williams v. Nat'l Interstate Ins. Co., No. 323343, 2016 WL 416496, at *4 (Mich. Ct. App. Feb. 2, 2016); Rivera v. City Of Battle Creek, No. 310951, 2013 WL 2495083, at*3 (Mich. Ct. App. June 11, 2013); Niva v. McCardell, No. 296847, 2011 WL 1519363, at *4 (Mich. Ct. App. Apr. 21, 2011); Duckworth v. Warren, 10 So. 3d 433, 438 (Miss. 2009); Fasch v. M.K. Weeden Const., Inc., 262 P.3d 1117, 1122 (Mont. 2011); Alfano v. Schaud, 60 A.3d 501, 505 (N.J. Super. Ct. App. Div. 2013); Steinberg v. Sahara Sam's Oasis, LLC, 2014 WL 5487564, at *9 (N.J. Super. Ct. App. Div. Oct. 31, 2014), rev'd, 142 A.3d 742 (N.J. 2016); Paez v. Burlington N. Santa Fe Ry., 362 P.3d 116, 123 (N.M. Ct. App. 2015); Perez v. City of Albuquerque, 276 P.3d 973, 975 (N.M. Ct. App. 2012); Rasmussen v. Hancock Cty. Comm'rs, No. 5-06-54, 2008 WL 2168874, at *7 (Ohio Ct. App. May 27, 2008); Sellers v. Twp. of Abington, 106 A.3d 679, 690 (Pa. 2014); Eisele v. Bond, No. 61663-3-I, 2009 WL 2008397, at*3 (Wash. Ct. App. 2009). Other formulations are possible as well. See, e.g., Martin v. Hallum, 374 S.W.3d 152, 159 (Ark. Ct. App. 2010) (citing Scott for the proposition that "we are not obliged to ignore incontrovertible evidence"); Lubar v. Connelly, 86 A.3d 642, 652 (Me. 2014) (citing Scott for "utterly discredited" standard). No state court summary judgment decision invoked the "blatantly contradicts" language prior to Scott.

141. See, e.g., Duckworth, 10 So. 3d at 438 (citing Scott approvingly but finding it not dispositive).

142. In one case, a Delaware court expressly reserved the question whether Scott changed the state's summary judgment standard. See Turner v. Ass'n of Owners of Bethany Seaview Condo., No. S11C-12-010 RFS, 2013 WL 1861930, at *3 (Del. Super. Ct. Apr. 26, 2013). Two subsequent decisions by the same court treated Turner as if it adopted Scott. See Gary v. R.C. Fabricators, Inc., No. 11C-12208 FSS, 2014 WL 4181479, at *18 (Del. Super. Ct. July 30, 2014); Council of Unit Owners of Windswept Condo. Ass'n v. Schumm, No. S12C-08-011 RFS, 2013 WL 6133621, at *6 (Del. Super. Ct. Nov. 20, 2013).

143. A conscious but implicit rejection of a precedent is hard to identify. In Fuhr v. Trinity Health Corp., the dissenting opinion relied on Scott while the majority did not. No. 309877, 2013 WL 1629301 (Mich. Ct. App. Apr. 16, 2013). Months later, the Michigan Supreme Court issued a one-sentence order reversing the Court of Appeals "for the reasons stated in the Court of Appeals dissenting opinion." See Fuhr v. Trinity Health Corp., 837 N.W.2d 275 (mem.) (2013). In other words, Michigan now follows Scott.

144. One additional difficulty in ascertaining the effects of Scott is that the Court in Scott was not explicit about how its opinion modified the deference afforded to plaintiffs in summary judgment. 
Some state courts, however, rejected the Supreme Court's earlier changes to summary judgment from the Celotex decision. ${ }^{145}$ There has not been a comprehensive study of state summary judgment practice in the wake of Celotex ${ }^{146}$ but my research reveals that fourteen states reject Celotex in whole or in part: ${ }^{147}$ Connecticut; ${ }^{148}$ Florida $;{ }^{149}$ Georgia $;{ }^{150}$ Indiana; ${ }^{151}$ Kentucky; $;{ }^{152}$

145. Celotex Corp. v. Catrett, 477 U.S. 317 (1986); see also Anderson v. Liberty Lobby, Inc., 477 U.S. 242 (1986); Matsushita Elec. Indus. Co. v. Zenith Radio Corp., 475 U.S. 574 (1986). Taken together, these decisions comprise the "summary judgment trilogy" or the "Celotex trilogy".

146. As with Twombly and Iqbal, there has been a vigorous debate about the effects of Celotex

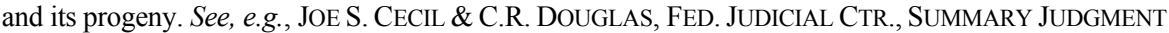
PRACTICE IN THREE DistRICT COURTS (1987); Eisenberg \& Clermont, supra note 5; Issacharoff \& Loewenstein, supra note 35; Jonah B. Gelbach, Rethinking Summary Judgment Empirics: The Life of the Parties, 162 U. PA. L. REV. 1663 (2014); Miller, supra note 35; Linda S. Mullenix, The 25th Anniversary of the Summary Judgment Trilogy: Much Ado About Very Little, 43 LOY. U. CHI. L.J. 561 (2012); Redish, supra note 35; Suja A. Thomas, Why Summary Judgment Is Unconstitutional, 93 VA. L. REV. 139 (2007).

147. The degree to which these courts "reject" Celotex varies, in part depending on the existing summary judgment standard of the state before Celotex.

148. See Adams v. Laval, No. CV126026706S, 2014 WL 7271874, at *3 (Conn. Super. Ct. Nov. 12 , 2014) ("[R]eliance [on Celotex] is misplaced .... [A] party moving for summary judgment under Connecticut's rules of practice bears a heavier burden than it would under the federal rules."); Tangari v. Am. Optical Corp., No. CV065003634S, 2013 WL 6171421, at *2 (Conn. Super. Ct. Nov. 1, 2013) (party moving for summary judgment has higher burden in Connecticut practice); Thomas v. A.O. Smith Corp., No. CV105029385S, 2012 WL 695550, at *2 (Conn. Super. Ct. Feb. 15, 2012) ("The defendant relies on the United States Supreme Court case of Celotex ... . If this court were bound by Rule 56 of the Federal Rules of Civil Procedure, the court would view defendant's argument more favorably."); Waste Conversion Techs., Inc. v. Midstate Recovery, LLC, No. AANCV044000948, 2008 WL 5481231, at *26 (Conn. Super. Ct. Dec. 3, 2008) (“Celotex is not the law of Connecticut.").

149. See Byrd v. BT Foods, Inc., 948 So. 2d 921, 923-24 (Fla. Dist. Ct. App. 4th Dist. 2007) (Celotex and progeny are "of limited precedential value in Florida summary judgment cases"); Lich v. N.C.J. Inv. Co., 728 So. 2d 1191, 1194 (Fla. Dist. Ct. App. 2d Dist. 1999) (higher burden on party moving for summary judgment in Florida); Green v. CSX Transp., Inc., 626 So. 2d 974, 975 (Fla. Dist. Ct. App. 1st Dist. 1993) (per curiam) ("Under Florida law ... the party moving for summary judgment is required to conclusively demonstrate the nonexistence of an issue of material fact ...."); 5G's Car Sales, Inc. v. Fla. Dept'. of Law Enf't, 581 So. 2d 212, 212 (Fla. Dist. Ct. App. 3d Dist. 1991) (“Celotex and similar cases do not represent the law of Florida on the issue.").

150. See First Union Nat'l. Bank of Ga. v. J. Reisbaum Co., 378 S.E.2d 317, 319 (Ga. Ct. App. 1989) (denying motion for rehearing based on Celotex, concluding that Georgia precedent controls); Hepner v. S. Ry. Co., 356 S.E.2d 30, 34 (Ga. Ct. App. 1987) (same).

151. See Jarboe v. Landmark Cmty. Newspapers of Ind., Inc., 644 N.E.2d 118, 123 (Ind. 1994) ("Indiana does not adhere to Celotex and the federal methodology."); Dennis v. Greyhound Lines, Inc., 831 N.E.2d 171, 173 (Ind. Ct. App. 2005) (noting a "distinct difference" between Indiana and federal summary judgment rules).

152. See Steelvest, Inc. v. Scansteel Serv. Ctr., Inc., 807 S.W.2d 476, 481-82 (Ky. 1991) (comparing Kentucky and federal approaches to summary judgment and noting "some similarities and many obvious differences"). 


Missouri; $;{ }^{153}$ New Mexico; ${ }^{154}$ New York; ${ }^{155}$ North Carolina; ${ }^{156}$ Oklahoma; $;{ }^{157}$
Oregon; ${ }^{158}$ Texas; ${ }^{159}$ Utah; $;{ }^{160}$ and Virginia. ${ }^{161}$ Another four states-Alabama, ${ }^{162}$

153. See ITT Commercial Fin. Corp. v. Mid-Am. Marine Supply Corp., 854 S.W.2d 371, 380 (Mo. 1993) (en banc) (highlighting different roles of summary judgment in Missouri and federal practice in light of Missouri's fact-pleading requirements); see also Powel v. Chaminade Coll. Preparatory, Inc., 197 S.W.3d 576, 591 n.7 (Mo. 2006) (en banc) (Wolff, C.J., concurring) ("Federal courts have often been overly aggressive in granting summary judgment under the Celotex trilogy of United States Supreme Court decisions. This, fortunately, has not been the case in Missouri courts although the standard stated is basically the same.").

154. See Romero v. Philip Morris Inc., 242 P.3d 280, 287-88 (N.M. 2010) ("New Mexico courts, unlike federal courts, view summary judgment with disfavor, preferring a trial on the merits ....We continue to refuse to loosen the reins of summary judgment ....").

155. See Yun Tung Chow v. Reckitt \& Colman, Inc., 950 N.E.2d 113, 118 (N.Y. 2011) (Smith, J., concurring) (cautioning litigants about the difference between New York and federal approaches to summary judgment).

156. See Metts v. Piver, 401 S.E.2d 407, 409 (N.C. Ct. App. 1991) ("North Carolina is not bound by Celotex."). But see Scarborough v. Dillard's, Inc., 693 S.E.2d 640, 644 (N.C. 2011) (citing Anderson v. Liberty Lobby, Inc., 477 U.S. 242 (1986)).

157. See Iglehart v. Bd. of Cty. Comm'rs, 60 P.3d 497, 501 \& n.9 (Okla. 2002) ("Oklahoma's summary adjudication process is similar, but not identical, to that followed in the federal judicial system.”); Kating v. City of Pryor ex rel. Mun. Util. Bd., 977 P.2d 1142, 1144 (Okla. Civ. App. 1998) ("[F]ederal summary judgment standards established in Celotex ... and other related federal cases are not specifically applicable in Oklahoma appellate review of summary judgments.").

158. See Jones v. Gen. Motors Corp., 939 P.2d 608, 615-16 (Or. 1997) (observing that Oregon did not adopt the Celotex trilogy).

159. See Casso v. Brand, 776 S.W.2d 551, 555-56 (Tex. 1989) ("Nothing in either decision [in Liberty Lobby or Celotex] compels us to abandon our established summary judgment procedure either generally or in the particular facts of this case."), superseded in part by, Tex. R. Civ. P. 116a(i) as amended; see also Huckabee v. Time Warner Entm't Co., L.P., 19 S.W.3d 413, 420-22 (Tex. 2000) (criticizing Liberty Lobby, 477 U.S. 242).

160. See Orvis v. Johnson, 177 P.3d 600, 603-04 (Utah 2008) ("While [Celotex] has been the law in the federal courts for over two decades now, it is not Utah law."); Harline v. Barker, 912 P.2d 433, 445 n.13 (Utah 1996) ("This court has not previously adopted the reasoning of the majority opinion in Celotex, which is not binding on us as a matter of law, and declines to do so today."); see also Jones \& Trevor Mktg., Inc. v. Lowry, 284 P.3d 630, 639 n.9 (Utah 2012) ("While we have not adopted Celotex in its entirety, there are significant portions of our jurisprudence that are entirely consistent with Celotex.").

161. See Realstar Realtors, LLC v. Glenn ex rel. Smith, No. CL99-186, 2001 WL 587489, at*5 (Va. Cir. Ct. May 23, 2001) (noting difference between Virginia and federal approaches to summary judgment but concluding the Virginia Supreme Court would be likely to apply the logic of Celotex in this case); Bhalala \& Shah, Inc. v. Quick Out Mkt., Inc., No. 131309, 1994 WL 1031171, at *2 n.4 (Va. Cir. Ct. May 2, 1994) (explaining that under Virginia law, a denial in a pleading is sufficient to bar summary judgment); Harleysville Mut. Ins. Co. v. Capital GMC Trucks, Inc., No. LT-2254-2, 1993 WL 945924, at *2 (Va. Cir. Ct. Jan. 22, 1993) (concluding that the Virginia Supreme Court has suggested a higher evidentiary burden for a party moving for summary judgment than under federal law).

162. See Berner v. Caldwell, 543 So. 2d 686, 688 (Ala. 1989), overruled by, Ex parte Gen. Motors Corp., 769 So. 2d 903, 909 (Ala. 1999). 
California, ${ }^{163}$ Louisiana, ${ }^{164}$ and Tennessee ${ }^{165}$-rejected Celotex at one time but have since adopted Celotex by statute or by judicial decision. ${ }^{166}$ Alaska, ${ }^{167}$ Idaho, ${ }^{168}$ New Jersey, ${ }^{169}$ and Wyoming ${ }^{170}$ apply Celotex, but they rejected its summary judgment cousin Anderson v. Liberty Lobby. ${ }^{171}$ Thus, state courts have demonstrated a willingness to reject the Supreme Court's modern summary judgment decisions, though not (or not yet) Scott v. Harris.

163. See Aguilar v. Atl. Richfield Co., 24 P.3d 493, 509 (Cal. 2001) ("[S]ummary judgment law in this state now conforms, largely but not completely, to its federal counterpart as clarified and liberalized in Celotex, Anderson, and Matsushita."); Krantz v. BT Visual Images, LLC, 107 Cal. Rptr. 2d 209, 213-15 (Cal. Ct. App. 2001) (chronicling dispute among California courts).

164. See Sassone v. Elder, 626 So. 2d 345, 351 (La. 1993) (noting difference between state and federal summary judgment practice; superseded by amendments to La. Code Civ. Proc. Ann. (1996)); see also Samaha v. Rau, 977 So. 2d 880, 883 (La. 2008) (noting that 1997 amendments to La. Code Civ. Proc. Ann. art. 966 (1996) mirrored the standard in Celotex).

165. See Hannan v. Alltel Publ'g Co., 270 S.W.3d 1, 5-6 (Tenn. 2008) (explaining that Tennessee adopted Justice Brennan's dissent in Celotex), overruled by Rye v. Women's Care Ctr., 477 S.W.3d 235, 261-63 (Tenn. 2015).

166. See supra notes 162-165.

167. See Greywolf v. Carroll, 151 P.3d 1234, 1241 (Alaska 2007) (applying Celotex); Moffatt v. Brown, 751 P.2d 939, 943 (Alaska 1988) (criticizing Anderson v. Liberty Lobby, Inc., 477 U.S. 242 (1986)).

168. See Chandler v. Hayden, 215 P.3d 485 (Idaho 2009) (applying Celotex); G\&M Farms v. Funk Irrigation Co., 808 P.2d 851, 854-55 (Idaho 1991) (declining to apply Liberty Lobby's approach outside of defamation cases); see also 10B CHARLES ALAN WRiGHT \& ARTHUR R. MILLER, FEDERAL PRACTICE AND PROCEDURE: CIVIL $§ 2730$ (4th ed. 2017 Update) (discussing the federal practice of applying Liberty Lobby, 477 U.S. 242 (1986) outside of defamation cases).

169. See Brill v. Guardian Life Ins. Co. of Am., 666 A.2d 146, 155-56 (N.J. 1995) (adopting standards from Celotex); Dairy Stores, Inc. v. Sentinel Publ'g Co., 516 A.2d 220, 235-36 (N.J. 1986) (criticizing Liberty Lobby, 477 U.S. 242 (1986)).

170. See Franks v. Olson, 975 P.2d 588, 593 (Wyo. 1999) (applying Celotex); Parker v. Haller, 751 P.2d 372, 376-77 (Wyo. 1988) (declining to adopt the standards from Liberty Lobby, 477 U.S. 242 (1986)).

171. 477 U.S. 242 (1986). Celotex and Liberty Lobby address different aspects of the summary judgment standard, so it would not be incoherent to adopt one and not the other. 
Table B-State Decisions on Celotex ${ }^{172}$

\begin{tabular}{|l|lll|}
\hline \multicolumn{1}{|c|}{ Rejecting Celotex } & \multicolumn{3}{|c|}{ Applying Celotex } \\
\hline Connecticut & Alabama* & Kansas & North Carolina* \\
Florida & Alaska & Louisiana* & North Dakota \\
Georgia & Arizona & Maine & Ohio \\
Indiana & Arkansas & Maryland & Pennsylvania \\
Kentucky & California* & Massachusetts & Rhode Island \\
Missouri & Colorado & Michigan & South Carolina \\
New Mexico & Dist. of & Minnesota & South Dakota \\
New York & Columbia & Mississippi & Tennessee* \\
Oklahoma & Delaware & Montana & Vermont \\
Oregon & Hawai'i & Nebraska & Washington \\
Texas & Idaho & Nevada & West Virginia \\
Utah & Illinois & New Hampshire & Wisconsin \\
Virginia & Iowa & New Jersey* & Wyoming \\
& & & \\
& $*$ Previously rejected Celotex & \\
\hline
\end{tabular}

\section{Class Actions}

Turning to class actions, Wal-Mart v. Dukes seemed to increase the evidentiary burden of establishing commonality among class members. ${ }^{173}$ Prior to this Article, there has been little scholarly attention on how states have reacted to Dukes. ${ }^{174}$

172. Case citations are available in Appendix 2.

173. Wal-Mart v. Dukes, 564 U.S. 338 (2011); see supra notes 41-45 and accompanying text.

174. As the foregoing demonstrates, there has been comparatively less attention to Dukes in the states. In part it may be because the Class Action Fairness Act (CAFA) sweeps into federal court many of the cases for which Dukes has the most bite. See infra note 279 and accompanying text. 
On the one hand, the highest state courts in Arkansas, ${ }^{175}$ Georgia, ${ }^{176}$ Louisiana, ${ }^{177}$ Montana,${ }^{178}$ Ohio, ${ }^{179}$ and Oklahoma, ${ }^{180}$ as well as lower courts in (at least) ${ }^{181}$ Delaware, ${ }^{182}$ Kansas, ${ }^{183}$ Kentucky, ${ }^{184}$ Missouri, ${ }^{185}$ Texas, ${ }^{186}$ and Washington, ${ }^{187}$ have endorsed the Dukes position on commonality.

On the other hand, a few state courts have rejected Dukes. ${ }^{188}$ In Soper v. Tire Kingdom, ${ }^{189}$ the Florida Supreme Court summarily reversed a lower court decision applying Dukes ${ }^{190}$ over a dissent trumpeting Dukes. ${ }^{191}$ Based on differences between the federal and state rules, New York's highest court explained in Jiannaras v. Alfant that "Wal-Mart has no bearing" on the

175. See CACH, LLC v. Echols, 506 S.W.3d 217, 222 (Ark. 2016).

176. See Georgia-Pacific Consumer Prods., LP v. Ratner, 762 S.E.2d 419, 421-22 (Ga. 2014); see also Deal v. Miller, 739 S.E.2d 487, 490-91 nn.11-12 (Ga. Ct. App. 2013); Rite Aid of Ga., Inc. v. Peacock, 726 S.E.2d 577, 579 (Ga. Ct. App. 2012).

177. See Price v. Martin, 79 So. 3d 960, 969 (La. 2011); see also Doe v. S. Gyms, LLC, 112 So. 3d 822, 829-30 (La. 2013) (following Price); Albe v. City of New Orleans, 174 So. 3d 212, 220-21 (La. Ct. App. 2015); Hill v. Hebert, 169 So. 3d 731, 733 (La. Ct. App. 2015) (same).

178. See Roose v. Lincoln Cty. Emp. Group Health Plan, 362 P.3d 40, 46 (Mont. 2015); Sangwin v. State, 315 P.3d 279, 284-85 (Mont. 2013); Jacobsen v. Allstate Ins. Co., 310 P.3d 452, 460-61 (Mont. 2013); Mattson v. Mont. Power Co., 291 P.3d 1209, 1219-20 (Mont. 2012); Chipman v. Nw. Healthcare Corp., 288 P.3d 193, 206-07 (Mont. 2012). Montana also has endorsed Comcast v. Behrend, 569 U.S. 27 (2013). See Byorth v. USAA Cas. Ins. Co., 384 P.3d 455, 460-61 (Mont. 2016).

179. See Felix v. Ganley Chevrolet, Inc., 49 N.E.3d 1224, 1230 (Ohio 2015); Cullen v. State Farm Mut. Auto. Ins. Co., 999 N.E.2d 614, 620-21 (Ohio 2013); Stammco, LLC v. United Tel. Co., 994 N.E.2d 408, 415-16 (Ohio 2013).

180. See Marshall Cty. v. Homesales, Inc., 339 P.3d 878, 884 (Okla. 2014).

181. California courts are split. Compare Strong v. Blue Cross of Cal., No. B231512, 2013 WL 241982, at *2-4 (Cal. Ct. App. 2d Dist. Jan. 23, 2013) (accepting Dukes), with Ammari Elecs. v. Pac. Bell Directory, No. A136801, 2014 WL 989166, at*11 (Cal. Ct. App. 1st Dist. Mar. 14, 2014) (rejecting Dukes). See also infra note 194 (discussing Connecticut). A Rhode Island court seemed to apply Dukes, but this decision is less clear than the others cited herein. See Providence Retired Police v. City of Providence, No. PC-11-5853, 2012 WL 1957737 (R.I. Super. Ct. May 24, 2012).

182. See Carroll v. Philip Morris USA, Inc., 163 A.3d 91, 107 \& n.77 (Del. Super. Ct. 2017)

183. See Johnson v. MKA Enters., No. 112,049, 2015 WL 4487037, at*4 (Kan. Ct. App. July 17, 2015).

184. See Haynes Trucking, LLC v. Hensley, No. 2013-CA-000190-ME, 2016 WL 930271, at*7 (Ky. Ct. App. Mar. 11, 2016).

185. See Lucas Subway MidMo, Inc. v. Mandatory Poster Agency, Inc., 524 S.W.3d 116, 129 30 (Mo. Ct. App. 2017).

186. See Lon Smith \& Assocs., Inc. v. Key, 527 S.W.3d 604, 618-19 (Tex. Ct. App. 2017); Peter G. Milne, P.C. v. Ryan, 477 S.W.3d 888, 914 (Tex. Ct. App. 2015); Bliss \& Glennon Inc. v. Ashley, 420 S.W.3d 379, 396 (Tex. Ct. App. 2014); Canyon Lake Island Prop. Owners Assoc. v. Sterling/Suggs Ltd. P'ship, No. 03-14-00208-CV, 2015 WL 3543125, at *2-3 (Tex. Ct. App. June 5, 2015).

187. See Admasu v. Port of Seattle, 340 P.3d 873, 878 n.18 (Wash. Ct. App. 2014).

188. In addition, at least two state decisions expressly rejected Comcast v. Behrend, 569 U.S. 27 (2013). See Williams v. Superior Court, 165 Cal. Rptr. 3d 340, 349 (Cal. Ct. App. 2013); Cardona v. Maramont Corp., No. 602877-2007, 2014 WL 2558176, at *13 (N.Y. Sup. Ct. June 6, 2014) ("[T]he court finds that Comcast and Dukes are not controlling.").

189. Soper v. Tire Kingdom, Inc., 124 So. $3 d 804$ (Fla. 2013) (per curiam).

190. Tire Kingdom, Inc. v. Dishkin, 81 So. 3d 437 (Fla. Dist. Ct. App. 2011).

191. Soper, 124 So. 3d at 804-07 (Canady, J., dissenting). The majority reaffirmed the state class action precedent laid out in Sosa v. Safeway Premium Finance Co., 73 So. 3d 91 (Fla. 2011). 
certification of a class in New York courts. ${ }^{192}$ In Migis v. Autozone, Inc., the Oregon Court of Appeals held that it "fail[ed] to see ... how Wal-Mart controls in this case, which resolves state claims and applies state class-certification procedures." " 193 A Connecticut Superior Court judge issued a long opinion critical of Dukes, rejecting its view of commonality under Connecticut law. ${ }^{194}$ California's intermediate appellate courts are split, ${ }^{195}$ with a recent decision stating flatly: "the applicable standard in California is not . . . stated in WalMart." ${ }^{, 196}$ Finally, although it did not address the commonality standard in particular, the Iowa Supreme Court devoted most of its thirty-two-page majority opinion in Pippen v. State to criticizing Dukes. ${ }^{197}$

State resistance to Dukes is particularly significant given another recent Roberts Court decision. In Smith v. Bayer, ${ }^{198}$ the Supreme Court explained that a state court may go forward with a class action under state procedural law ${ }^{199}$ after a denial of class certification in federal court. ${ }^{200}$ Therefore, state court deviation from Dukes is significant not only for cases first filed in state court, but also for state class actions filed after certification is denied in federal court. ${ }^{201}$

\section{B. Standing in State Courts}

The previous Section explored how state courts have declined to follow the Supreme Court's interpretation of the Federal Rules. State courts may also sidestep the Court's procedural decisions rooted in Article III of the Constitution.

192. 52 N.E.3d 1166, 1169 (N.Y. 2016); see also Cardona, 2014 WL 2558176, at *13 (rejecting Dukes and citing other New York cases).

193. 387 P.3d 381, 389 (Or. Ct. App. 2016).

194. See Dougan v. Sikorsky Airline Corp., No. X03CV126033069, 2016 WL 921779 (Conn. Super. Ct. Feb. 11, 2016). The court predicted: "it is unlikely that the Connecticut Supreme Court would adopt the Wal-Mart standard." Id. at *3. An earlier Connecticut opinion from the same court seemingly endorsed Dukes, though its endorsement was more equivocal than Dougan's rejection. See Sal's Glass Co., LLC v. Duplicating Methods Co., No. HHDCV106016006S, 2013 WL 1407500, at *4 (Conn. Super. Ct. Mar. 22, 1013) (looking to Dukes and authority from other states in the absence of Connecticut precedent).

195. See supra note 181.

196. Ammari Elecs. v. Pac. Bell Directory, No. 2014 WL 989166, 2014 WL 989166, at*11 (Cal. Ct. App. 1st Dist. Mar. 14, 2014) (internal quotation marks omitted).

197. See 854 N.W.2d 1 (Iowa 2014). The Iowa Supreme Court was most critical of Dukes's interpretation of Title VII and its view of workplace discrimination, but it also mentioned the potential persuasive effect of the Dukes dissenters for issues such as commonality: "[W]ith respect to Wal-Mart, we have had no occasion to consider whether the majority or minority opinion in this 5-4 decision has the most persuasive power." Id. at 18.

198. Smith v. Bayer Corp., 564 U.S. 299 (2011).

199. In Smith, the state class action was filed in West Virginia court. Id. at 303. Although West Virginia has not endorsed or departed from Dukes, its class action law deviates from the federal approach in other ways. See id. at 310 (citing In re W. Va. Rezulin Litig., 585 S.E.2d 52 (2003)).

200. See id. at 304-05. The Anti-Injunction Act barred the federal court from enjoining the state suit, and the federal decision was not preclusive. Id. at 307-12.

201. As explained below, a separate suit would be necessary because denial of certification is not a basis for remand if removal had been based on CAFA. See infra note 279. 
Although the US Constitution applies in state courts, ${ }^{202}$ Article III regulates only the power of the federal courts-state courts are thus free to depart from constitutional constraints on federal justiciability. ${ }^{203}$ This Section will focus on standing, though other Article III doctrines may be subject to similar analysis. ${ }^{204}$

The mechanism for state court deviation from federal standing law is straightforward: state courts simply decline to incorporate the federal court understanding of Article III into state constitutional or common law. In fact, state courts frequently depart from the federal approach to justiciability. ${ }^{205}$ To give an example paralleling earlier analysis, a number of state court decisions have expressly rejected Lujan's approach to standing as a requirement for state justiciability. ${ }^{206}$ More generally, Helen Hershkoff exhaustively described state court deviations from various federal justiciability doctrines. ${ }^{207}$ For example, she noted that virtually every state provides for taxpayer standing. ${ }^{208}$ Hershkoff did not focus on the type of statutorily defined injury at issue in Spokeo and other cases, ${ }^{209}$ but it turns out that many states also deviate from this federal approach by recognizing statutorily created standing. ${ }^{210}$

202. See U.S. CONST. art VI, cl. 2 (Supremacy Clause).

203. Id. This Section focuses on states applying standing doctrine that is broader than Article III. State courts may be restricted in their ability to limit standing for federal claims proceeding in state court. Cf. Testa v. Katt, 330 U.S. 386, 392-94 (1947) (requiring state court to exercise jurisdiction over federal claim).

204. For recent statements of federal court justiciability law, see, for example, MedImmune, Inc. v. Genentech, Inc., 549 U.S. 118 (2007) (ripeness); Genesis Healthcare Corp. v. Symczyk, 569 U.S. 1523 (2013) (mootness); Zivotofsky v. Clinton, 566 U.S. 189 (2012) (political questions). For further elaboration of the relationship to state courts, see Clopton, supra note 65.

205. For an example that got the attention of the Supreme Court, see Nike, Inc. v. Kasky, 539 U.S. 654, 661 (2003) (per curiam) (Stevens, J., concurring) (noting that California's unfair competition law allowed a private attorney general to sue Nike in state court for misrepresentations regarding foreign working conditions even though plaintiff would have been unable to establish Article III standing).

206. See, e.g., Citizens for Protection of N. Kohala Coastline v. County of Hawai'i, 979 P.2d 1120, 1127 (Haw. 1999); Nefedro v. Montgomery Cty., 996 A.2d 850, 854 n.3 (Md. 2010); Lansing Sch. Educ. Ass'n v. Lansing Bd. Of Educ., 792 N.W.2d 686, 693-96 (Mich. 2010); Goldston v. State, 637 S.E.2d 876, 882 (N.C. 2006); Hous. Auth. of Chester v. Pa State. Civil Serv. Comm'n, 730 A.2d 935, 939-41 (Pa. 1999); In re Petition for Declaratory Ruling re SDCL 62-1-1(6), 877 N.W.2d 340, 348 n. 15 (S.D. 2016); Wells Fargo Bank, N.A. v. Alexander, No. 2012AP2236, 2013 WL 4104472, at *4 n.5 (Wis. Ct. App. 2013).

207. See Helen Hershkoff, State Courts and the "Passive Virtues": Rethinking the Judicial Function, 114 HARV. L. REV. 1833, 1842-75 (2001) (reviewing advisory opinions, public actions, mootness, political questions, and nonjudicial functions).

208. See id. at 1854.

209. See supra notes 66-68 and accompanying text (discussing Spokeo).

210. See, e.g., Ex parte BAC Home Loans Servicing, LP, 159 So. 3d 31, 40-46 (Ala. 2013); Dep't of Revenue v. Kuhnlein, 646 So. 2d 717, 720 (Fla. 1994); Lansing Sch. Educ. Ass'n, 792 N.W.2d at 699; Webb Golden Valley, LLC v. State, 865 N.W.2d 689, 693 (Minn. 2015); City of Picayune v. S. Reg'l Corp., 916 So. 2d 510, 525-28 (Miss. 2005); Hous. Auth. of Chester, 730 A.2d at 939-41; Youngblood v. S.C. Dep't of Soc. Servs., 741 S.E.2d 515, 518 (S.C. 2013); Small v. Fed. Nat'l Mortg. Ass'n, 747 S.E.2d 817, 820 (Va. 2013). 
Furthermore, state courts have the authority to apply their local standing requirements to federal claims. ${ }^{211}$ In ASARCO v. Kadish, the Supreme Court explained that state courts may adjudicate federal claims that would not satisfy Article III's case-or-controversy requirement if brought in federal court. ${ }^{212}$ Though not exceedingly common, state courts have adjudicated federal claims for which federal justiciability was in doubt. ${ }^{213}$ For example, in Keyhea $v$. Rushen, California taxpayers brought suit in state court under Section 1983, alleging third-party harms to prisoners from the use of psychotropic drugs against their will, even though they would have lacked standing in federal court. ${ }^{214}$ In New Jersey Citizen Action v. Riviera Motel, a nonprofit association pursued a claim under the federal Americans with Disabilities Act, even though it appeared to lack federal standing. ${ }^{215}$ In Marriage of Gilbert, a Washington court found standing under state law to enforce requirements of the Federal Child Support and Establishment of Paternity Act where federal standing seemed doubtful. ${ }^{216}$ And in Smith v. Wisconsin Department of Agriculture, Trade \& Consumer Protection, the Seventh Circuit ordered remand of a nonjusticiable federal constitutional claim to the state court. ${ }^{217}$ The court explained:

While some consider it odd that a state court might have the authority to hear a federal constitutional claim in a setting where a federal court would not, it is clear that Article III's "case or controversy" limitations apply only to the federal courts. ... Wisconsin's doctrines of standing and ripeness are the business of the Wisconsin courts, and it is not for us to venture how the case would there be resolved. ${ }^{218}$

211. Federal statutes are regularly enforced in state courts unless Congress says otherwise. Indeed, prior to Reconstruction, there was no grant of general federal question jurisdiction, so many federal law claims were presumptively adjudicated in state courts. See 18 Stat. 470 (1875) (conferring federal question jurisdiction on the federal circuit courts for suits with an amount in controversy exceeding five hundred dollars).

212. See 490 U.S. 605, 617 (1989) ("[S]tate courts are not bound by the limitations of a case or controversy or other federal rules of justiciability even when they address issues of federal law, as when they are called upon to interpret the Constitution or, in this case, a federal statute."). ASARCO also explained that the Supreme Court could review such a decision "if the judgment of the state court causes direct, specific, and concrete injury to the parties who petition for our review ... . "Id. at 623-24.

213. ASARCO itself, and related cases, raised claims pursuant to the federal Arizona-New Mexico Enabling Act. See, e.g., ASARCO, 490 U.S. 605; Mayer Unified Sch. Dist. v. Winkleman, 207 P.3d 631 (Ariz. Ct. App. 2008); Jeffries v. Hassell, 3 P.3d 1071 (Ariz. Ct. App. 1999).

214. See 5 Cal. Rptr. 2d 762, 763 (Cal. Ct. App. 1992) (depublished). Ultimately, plaintiffs did not prevail on their federal law claim, but they obtained attorney fees under Section 1988 based on a successful state law claim. Id.

215. See 686 A.2d 1265, 1271-72 (N.J. Super. Ct. App. Div. 1997); see also Monahan Office Complex, LTD v. Borough of Dunmore, No. 1205 C.D.2014, 2015 WL 5444903, at *3-6 (Pa. Commw. Ct. 2015) (hypothesizing a possible suit under Pennsylvania standing law but finding no state law standing on these facts).

216. See 945 P.2d 238, 243 (Wash. Ct. App. 1997).

217. See 23 F.3d 1134, 1142 (7th Cir. 1994).

218. Id. (citations omitted); see also Me. Ass'n of Interdependent Neighborhoods v. Me. Dep't of Human Servs., 876 F.2d 1051, 1054 (1st Cir. 1989) (holding that the district court should remand, rather than dismiss, a case raising a substantial federal issue in which plaintiff lacked Article III 
State court decisions deviating from Article III highlight a tension in the Supreme Court's justiciability jurisprudence. On the one hand, many cases holding that Congress may not confer constitutional standing frame the doctrine as manifesting a separation-of-powers constraint on federal courts. This is the view articulated in Spokeo and the three earlier cases it cited for that proposition, ${ }^{219}$ which is consistent with the more general view of the case-orcontroversy requirement as a constraint on the judicial branch. ${ }^{220}$ In this light, decisions on the federal allocation of authority are simply unrelated to the separation of powers in the states, particularly given the background assumption of limited federal and general state courts. ${ }^{221}$

On the other hand, the Lujan decision suggested that, in the context of private enforcement, standing doctrine stops Congress from encroaching on the executive's duty to take care that the laws are enforced. ${ }^{222}$ Admittedly, the Court (and Lujan-author Justice Scalia) seemed to step back from this view of standing in Steel Co. v. Citizens for a Better Environment, ${ }^{223}$ but it is a defensible view of the doctrine and one that persuaded some justices over time. ${ }^{224}$ This view of

standing); Salorio v. Glaser, 414 A.2d 943 (N.J. 1980) (seemingly entertaining federal constitutional claim where federal standing is questionable); Urban League v. Mahwah Twp., 370 A.2d 521 (N.J. Super. App. Div. 1977) (same).

219. See 136 S. Ct. at 1548. Spokeo cited a footnote from Raines v. Byrd, which is appended to the phrase: "In the light of this overriding and time-honored concern about keeping the Judiciary's power within its proper constitutional sphere ...." 521 U.S. 811, 820 (1997). The two other cases cited by Spokeo are equally clear that Article III is about constraining the courts. See Summers v. Earth Island Inst., 555 U.S. 488, 492-93 (2009); Gladstone, Realtors v. Village of Bellwood, 441 U.S. 91, 99 (1979).

220. See, e.g., Clapper v. Amnesty Int'l USA, 133 S. Ct. 1138, 1146 (2013) ("The law of Article III standing, which is built on separation-of-powers principles, serves to prevent the judicial process from being used to usurp the powers of the political branches.”); United Pub. Workers v. Mitchell, 330 U.S. 75, 90-91 (1947) ("Judicial adherence to the doctrine of the separation of powers preserves the courts for the decision of issues, between litigants, capable of effective determination.").

221. See, e.g., ERWIN CHEMERINSKY, FEDERAL JURISDICTION $§ 5.1$ (4th ed. 2003); Nw. Airlines, Inc. v. Transp. Workers Union, 451 U.S. 77, 95 (1981) (“[F]ederal courts, unlike their state counterparts, are courts of limited jurisdiction ....").

222. See Lujan v. Defs. of Wildlife, 504 U.S. 555, 577 (1992) (citation omitted) ("If the concrete injury requirement has the separation-of-powers significance we have always said, the answer must be obvious: To permit Congress to convert the undifferentiated public interest in executive officers' compliance with the law into an 'individual right' vindicable in the courts is to permit Congress to transfer from the President to the courts the Chief Executive's most important constitutional duty, to 'take Care that the Laws be faithfully executed."').

223. See 523 U.S. 83, 102 n.4 (1998) (citations and internal quotation marks omitted) ("Our opinion is not motivated . . . by the more specific separation-of-powers concern that this citizen's suit somehow interferes with the Executive's power to 'take Care that the Laws be faithfully executed.' The courts must stay within their constitutionally prescribed sphere of action, whether or not exceeding that sphere will harm one of the other two branches. This case calls for nothing more than a straightforward application of our standing jurisprudence, which, though it may sometimes have an impact on Presidential powers, derives from Article III and not Article II.").

224. See, e.g., Lujan, 504 U.S. at 577 (Scalia, J., joined by Rehnquist, C.J., and White, Kennedy, Souter, Thomas, JJ.); Spokeo, 136 S. Ct. at 1552-53 (Thomas, J., concurring) (“'[B]y limiting Congress' ability to delegate law enforcement authority to private plaintiffs and the courts, standing doctrine preserves executive discretion."); see also William A. Fletcher, The Structure of Standing, 98 YALE L.J. 221,233 (1988) ("Where standing to enforce statutorily established duties is at issue, an 'injury in fact' 
standing law cuts against state courts hearing "no-standing" federal claims. It would be odd to protect executive authority by denying Congress the ability to create private actions in federal court but allow Congress to create private actions in state courts instead. And yet, broader state justiciability rules invite exactly this sort of lawmaking. ${ }^{225}$ Indeed, Congress seemingly could create insulated causes of action for which state court jurisdiction is exclusive ${ }^{226}$ or removal is prohibited. $^{227}$

In any event, under current law, state courts may entertain state and federal suits even if plaintiffs would lack Article III standing in federal court.

\section{International Law in State Courts}

International law cases represent another area in which the Supreme Court's procedural decisions have attracted criticism, ${ }^{228}$ and they represent another area where state courts may provide remedies in spite of procedural retrenchment in the federal courts.

First, after a short period in which Alien Tort Statute (ATS) litigation was in vogue, the Supreme Court's recent ATS decisions have put a damper on international human rights litigation in federal court. ${ }^{229}$ But the ATS is a statute governing federal subject-matter jurisdiction. ${ }^{230}$ Much like Article III, federal subject-matter jurisdiction statutes do not bind state courts, ${ }^{231}$ and indeed, federal jurisdictional law is premised on the backstop of state courts of general

requirement operates as a limitation on the power normally exercised by a legislative body."); Michael C. Dorf, Supreme Court Requires "Concrete" Injury for Standing, VERDICT (May 18, 2016), https://verdict.justia.com/2016/05/18/supreme-court-requires-concrete-injury-standing

[https://perma.cc/52XB-L6MA] ("Congressional authorization of private lawsuits to compel enforcement could ... be seen as an effort to shift power from the president to Congress. Accordingly, prior standing cases expressly invoke separation of powers.").

225. See supra notes 213-216.

226. For example, in Mims v. Arrow Financial Services, LLC, the Court entertained but ultimately rejected multiple circuits' interpretation of the Telephone Consumer Protection Act that provided for exclusive state court jurisdiction. 565 U.S. 368 (2012) (citing cases and statutory language). Other statutes impliedly grant state courts exclusive jurisdiction over low-value federal claims. For example, the federal question statute included an amount-in-controversy requirement until 1980, see 94 Stat. 2369 (1980) (amending 28 U.S.C. $§ 1331$ to remove amount-in-controversy requirement), and some federal law claims retain special amount-in-controversy requirements, see, e.g., 28 U.S.C. $\S$ 1337(a) (2012) (amount-in-controversy for claims under 49 U.S.C. $\S \S 11706,14706$ ).

227. See, e.g., 28 U.S.C. $§ 1445$ (a) (2012) (limiting removal of FELA claims).

228. See supra notes $94-95$ and accompanying text.

229. See Kiobel v. Royal Dutch Petroleum Co., 569 U.S. 108, 115-17 (2013) (applying the presumption against extraterritoriality to claims under the ATS); Sosa v. Alvarez-Machain, 542 U.S. 692, 728-38 (2004) (defining requirements for ATS jurisdiction).

230. 28 U.S.C. $\$ 1350$ (2012); see also Sosa, 542 U.S at 729 ("All Members of the Court agree that $\S 1350$ is only jurisdictional.”).

231. Professor Coleman made a similar observation about other Roberts Court subject-matter jurisdiction decisions. See Brooke D. Coleman, Civil-izing Federalism, 89 TuL. L. REV. 307, 360-65 (2014). 
jurisdiction. ${ }^{232}$ Lawyers have brought international human rights cases in state courts for decades. ${ }^{233}$ If one of these cases were removed to federal court, a finding of no jurisdiction under the ATS should result in remand to state court $^{234}$ - and it has. ${ }^{235}$ (Note also that many ATS cases are founded on state law causes of action, ${ }^{236}$ so they are not always candidates for federal question jurisdiction. ${ }^{237}$ ) Indeed, some plaintiffs have filed putative ATS suits and state court cases on the same claims. ${ }^{238}$ Admittedly there are other hurdles to successful international cases in state courts. ${ }^{239}$ But because many of these limits are judicially created doctrines, state courts could change those too. ${ }^{240}$

A related set of responses is also available to the Supreme Court's decisions holding that habeas petitions based on the Vienna Convention on Consular Relations are subject to state procedural-default rules. ${ }^{241}$ While commentators have lamented this as an example of the United States flouting international law, ${ }^{242}$ the situation was more complex than it seemed. For present purposes, the

232. For example, the amount-in-controversy requirement for diversity jurisdiction essentially allocates cases between federal and state courts based on potential recovery. See 28 U.S.C. $\S 1332$ (2012).

233. See Paul L. Hoffman, The Application of International Human Rights Law in State Courts: A View from California, 18 INT'L LAW. 61, 65 (1984); Paul Hoffman \& Beth Stephens, International Human Rights Cases Under State Law and in State Courts, 3 U.C. IRVINE L. REV. 9, 11 (2013). For an interesting parallel, note that the Iowa Supreme Court, interpreting the Iowa Constitution, rejected the Supreme Court's recent limits on finding causes of actions directly under the federal Constitution (i.e., Bivens). See Godfrey v. State, 898 N.W.2d 844 (Iowa 2017) (making this point and collecting sisterstate cases).

234. See 28 U.S.C. $§ 1441$ (2012) (limiting removal to "any civil action brought in a State court of which the district courts of the United States have original jurisdiction").

235. See, e.g., Miner v. Begum, 8 F. Supp. 2d 643 (S.D. Tex. 1998), aff'd, No. 99-20027, 2000 WL 554953 (5th Cir. Apr. 20, 2000); Alomang v. Freeport-McMoran Inc., No. 96-2139, 1996 WL 601431, at *9-10 (E.D. La. Oct. 17, 1996).

236. See Hoffman \& Stephens, supra note 233, at 15-17 (collecting sources). This includes the claims involved in the Supreme Court's major ATS decision in Sosa v. Alvarez-Machain, 542 U.S. 692 (2004).

237. See 28 U.S.C. $§ 1331$ (2012). But see Sequihua v. Texaco, Inc., 847 F. Supp. 61, 63 (S.D. Tex. 1994) (finding, unusually, subject-matter jurisdiction based on a federal common law of foreign relations). Diversity jurisdiction is also unavailable in many of these cases because it applies to foreigncitizen plaintiffs suing foreign-citizen defendants. See U.S. CoNST. art. III, § 2; 28 U.S.C. § 1332 (2012).

238. See Ayemou v. Amvac Chem. Corp., 312 F. App'x 24 (9th Cir. 2008) (describing federal and state actions against Dow Chemical and Shell Oil for chemical exposure in the Ivory Coast); Hereros ex rel. Riruako v. Deutsche Afrika-Linien Gmblt \& Co., 232 F. App'x 90, 93 \& n.1 (3d Cir. 2007) (describing overlapping federal and D.C. suits); Bano v. Union Carbide Corp., 273 F.3d 120, 122-25 (2d Cir. 2001) (adjudicating the Bhopal disaster ATS case and noting overlapping suits filed in state courts).

239. See, e.g., Hoffman \& Stephens, supra note 233, at 17-20.

240. Personal jurisdiction presents an obstacle to these suits that state courts cannot change. See infra Part II.D. At a minimum, though, these state options could help with cases against US-based defendants or defendants engaged in relevant conduct within the United States (thus supporting specific jurisdiction). See id.

241. See Medellin v. Texas, 552 U.S. 491, 523 (2008); Breard v. Greene, 523 U.S. 371, 375 (1998).

242. See supra note 95 (collecting sources). 
most interesting aspect of Medellin $v$. Texas was a seemingly tossed off reference to the State of Oklahoma in Justice Stevens's opinion concurring in the judgment. ${ }^{243}$ In a paragraph explaining the low cost of an evidentiary hearing, Justice Stevens noted that this "is a cost that the State of Oklahoma unhesitatingly assumed." ${ }^{244}$ In a footnote, Justice Stevens explained that, in another habeas case, an Oklahoma state court honored the United States' obligations under the Vienna Convention and granted an evidentiary hearing to determine whether the violation of the Vienna Convention prejudiced the defendant. ${ }^{245}$ Justice Stevens's opinion was not only a plaudit to Oklahoma, but also was a signal to other states that this option was available to them as well. ${ }^{246}$ The Supreme Court of Nevada took Justice Stevens up on his suggestion and ordered an evidentiary hearing in a Vienna Convention case ${ }^{247}$ - a hearing that ultimately led the lower court to vacate the petitioner's death sentence on Vienna Convention grounds. ${ }^{248}$ Currently, the Supreme Court of Ohio is considering this issue, ${ }^{249}$ and other states could follow suit.

State courts are not the only bodies that can give effect to the Vienna Convention. State legislatures could adjust state habeas procedures by statute. State executives can act too, and indeed the Governor of Oklahoma commuted the death sentence of the habeas petitioner in the example above. ${ }^{250}$ More generally, there are substantial opportunities in the American system for states to play a role in international affairs, ${ }^{251}$ including in treaty implementation. ${ }^{252}$ States have been active in implementing private law treaties such as the

243. See Medellin, 552 U.S. at 536-37 \& n.4 (Stevens, J., concurring in the judgment).

244. Id. at 537.

245. See id. at 537 n.4 (citing Torres v. State, No. PCD-04-442, 2004 WL 3711623 (Okla. Crim. App. May 13, 2004)).

246. This is a different type of Supreme Court signal than those addressed by Richard M. Re, Narrowing Supreme Court Precedent from Below, 104 GEO. L.J. 921, 966-71 (2016), but no less clear.

247. See Gutierrez v. State, No. 53506, 2012 WL 4355518, at *3 (Nev. Sept. 19, 2012).

248. See Gutierrez v. State, Order Post Evidentiary Hearing, No. CR94-1795B at 12-34 (Nev. 2d. Jud. Dist. Ct. Aug. 21, 2017).

249. For background on this case, see generally Loza v. Mitchell, 766 F.3d 466 (6th Cir. 2014).

250. See Medellin, 552 U.S. at 537 n.4 (Stevens, J., concurring in the judgment).

251. See, e.g., Julian G. Ku, The State of New York Does Exist: How the States Control Compliance with International Law, 82 N.C. L. REV. 457, 499-527 (2004) (collecting examples); Peter J. Spiro, Globalization and the (Foreign Affairs) Constitution, 63 OHIO ST. L.J. 649 (2002) (offering a theory of state involvement in foreign affairs).

252. See, e.g., $\mathrm{Ku}$, supra note 251, at 499-506. For example, at least one state has deviated from the Supreme Court's interpretation of the Hague Convention on the Taking of Evidence Abroad in Civil or Commercial Matters. The Supreme Court held that use of the Convention is optional. See Societe Nationale Industrielle Aerospatiale v. U.S. Dist. Court, 482 U.S. 522, 529 (1987). New Jersey state courts accept that the Convention is optional, but as one state court explained, "we perceive no conflict with federal supremacy, if, in exercising the option to resort to the Convention, we are more generous in our use of the Convention's procedures than the United States' courts." Husa v. Laboratoires Servier SA, 740 A.2d 1092, 1095 (N.J. Super. Ct. App. Div. 1999). 
International Wills Convention ${ }^{253}$ but arguments in favor of state participation are not limited to private law. ${ }^{254}$ There may be reasons to be cautious about states implementing international law, ${ }^{255}$ but this Section demonstrates that such opportunities exist.

\section{Personal Jurisdiction in State Courts}

Although state courts are not bound by Article III standing law, the Supreme Court's constitutional decisions on personal jurisdiction apply directly in state courts. ${ }^{256}$ In other words, state courts cannot deviate from personal jurisdiction law as they have done from other procedural doctrines described herein. However, state courts may be able to skirt the intention of the Supreme Court's personal jurisdiction decisions while remaining true to those decisions as written.

The Roberts Court's personal jurisdiction decisions have not addressed the traditional jurisdictional basis of consent. ${ }^{257}$ States interested in increasing personal jurisdiction over corporate defendants could treat state corporateregistration statutes as constituting jurisdictional consent. ${ }^{258}$ Tanya Monestier has been at the forefront of analyzing this option: ${ }^{259}$ courts in at least ten states

253. Convention Providing a Uniform Law on the Form of an International Will, 12 I.L.M. 1302, Oct. 26, 1973, incorporated in, UNIF. PROBATE CODE art. II, pt. 10 (2010); see also Ku, supra note 251, at 501-04.

254. See, e.g., David Kaye, State Execution of the International Covenant on Civil and Political Rights, 3 U.C. IRVINE L. REV. 95, 117-19 (2013); Ku, supra note 251, at 521-26.

255. See, e.g., Ku, supra note 251, at 468-70 (collecting sources); Spiro, supra note 251, 686-97 (collecting sources).

256. See supra notes 77-86 and accompanying text; see also U.S. CONST. amends. V, XIV. In theory, personal jurisdiction in federal court could be broader than in state court- the Fifth Amendment may allow more than the Fourteenth. See, e.g., Bristol-Myers Squibb Co. v. Superior Court, 137 S. Ct. 1773, 1784 (2017) (leaving this question open); Omni Capital Int'l, Ltd. V. Rudolf Wolff \& Co., 484 U.S. 97, $102 \mathrm{n} .5$ (1987) (same). But state courts would lack jurisdiction in any case that failed the federal court test as well.

257. See, e.g., Pa. Fire Ins. Co. v. Gold Issue Mining \& Milling Co., 243 U.S. 93, 95-96 (1917) (finding that consent is a valid basis for personal jurisdiction); Pennoyer v. Neff, 95 U.S. 714, 733 (1877) (acknowledging jurisdiction based on "voluntary appearance").

258. See Tanya J. Monestier, Registration Statutes, General Jurisdiction, and the Fallacy of Consent, 36 CARDOZO L. REV. 1343, 1363 n.109 (2015) (collecting statutes for every state).

259. See id. at 1377-1401. 
have found general jurisdiction based on corporate-registration consent, ${ }^{260}$ and courts in another six states have found specific jurisdiction on this basis. ${ }^{261}$

The Supreme Court's recent decisions on personal jurisdiction have seemingly nudged state actors both towards and away from finding consentbased personal jurisdiction. On the one hand, the Supreme Court of Delaware relied on Daimler and Goodyear to hold that its state corporate-registration statute did not confer personal jurisdiction. ${ }^{262}$ On the other hand, as a conscious response to Daimler, New York legislators have proposed at least four bills to amend state registration law to make jurisdictional consent express. ${ }^{263}$ None of this is to say that such statutes would pass constitutional muster-in addition to direct challenges under the Due Process Clause, ${ }^{264}$ these statutes also must survive objections as unconstitutional conditions ${ }^{265}$ and restraints on interstate commerce. ${ }^{266}$ But consent-based jurisdiction remains a potential channel for states to reject the Supreme Court's procedural retrenchment.

\section{E. State Court Assessment}

This Section shows that state courts have at times exercised their prerogative to deviate from the Supreme Court's decisions on the Federal Rules

260. See, e.g., Bane v. Netlink, Inc., 925 F.2d 637, 640-41 (3d Cir. 1991) (Pa.); Bohreer v. Erie Ins. Exch., 165 P.3d 186, 191-94 (Ariz. Ct. App. 2007); Allstate Ins. Co. v. Klein, 422 S.E.2d 863, 864 65 (Ga. 1992); Confederation of Can. Life Ins. Co. v. Vega y Arminan, 144 So. 2d 805, 808-10 (Fla. 1962); Rykoff-Sexton, Inc. v. Am. Appraisal Assocs., Inc., 469 N.W.2d 88, 89-90 (Minn. 1991); Read v. Sonat Offshore Drilling, Inc., 515 So. 2d 1229, 1230-31 (Miss. 1987); Allied-Signal Inc. v. Purex Indus., Inc., 576 A.2d 942, 943-45 (N.J. Super. Ct. App. Div. 1990); Werner v. Wal-Mart Stores, Inc., 861 P.2d 270, 272-74 (N.M. Ct. App. 1993); Augsbury Corp. v. Petrokey Corp., 470 N.Y.S.2d 787, 789 (N.Y. App. Div. 1983); Green Mountain Coll. v. Levine, 139 A.2d 822, 824-25 (Vt. 1958); see also Merriman v. Crompton Corp., 146 P.3d 162, 171-77 (Kan. 2006) (the corporate-registration statute has since been repealed). The Oregon Supreme Court recently interpreted its statute as not providing this consent. See Figueroa v. BNSF Ry. Co., 390 P.3d 1019, 1030 (Or. 2017).

261. See, e.g., Holloway v. Wright \& Morrissey, Inc., 739 F.2d 695, 697-99 (1st Cir. 1984) (N.H.); Grey Line Tours v. Reynolds Elec. \& Eng'g Co., 238 Cal. Rptr. 419, 421-22 (Cal. Ct. App. 1987); Staley-Wynne Oil Corp. v. Loring Oil Co., 162 So. 756, 757-59 (La. 1935); Springle v. Cottrell Eng'g Corp., 391 A.2d 456, 459-69 (Md. Ct. Spec. App. 1978); Mittelstadt v. Rouzer, 328 N.W.2d 467, 469-70 (Neb. 1982); Osage Oil \& Ref. Co. v. Interstate Pipe Co., 253 P. 66, $69-70$ (Okla. 1926); Eure v. Morgan Jones \& Co., 79 S.E.2d 862, 863-68 (Va. 1954).

262. See Genuine Parts Co. v. Cepec, 137 A.3d 123, 125-26 (Del. 2016) (citing Goodyear Dunlop Tires v. Brown, 564 U.S. 915 (2011), and Daimler v. Bauman, 134 S. Ct. 746 (2014)) (overruling Sternberg v. O'Neil, 550 A.2d 1105, 1109-16 (Del. 1988)).

263. See S.B. 4846, 238th Leg., Reg. Sess. (N.Y. 2015); A.B. 6714, 238th Assemb., Reg. Sess. (N.Y. 2015); S.B. 7078, 237th Leg., Reg. Sess. (N.Y. 2014); A.B. 9576, 237th Assemb., Reg. Sess. (N.Y. 2014). Most states' registrations statutes only imply consent to personal jurisdiction. But in Pennsylvania, and perhaps someday in New York, consent to jurisdiction is express in the relevant statute. 42 PA. CONS. STAT. $\S 5301$ (2017).

264. See, e.g., Olberding v. Ill. Cent. R.R. Co., 346 U.S. 338, 340-41 (1953) (referring to implied jurisdictional consent as "Alice in Wonderland").

265. See D. Craig Lewis, Jurisdiction over Foreign Corporations Based on Registration and Appointment of an Agent: An Unconstitutional Condition Perpetuated, 15 DEL. J. CORP. L. 1 (1990).

266. See, e.g., T. Griffin Vincent, Toward A Better Analysis for General Jurisdiction Based on Appointment of Corporate Agents, 41 BAYLOR L. REV. 461, 482-85 (1989). 
of Civil Procedure, Article III, and international law. ${ }^{267}$ State court deviations from Twombly and Iqbal, for example, are not just a dream of law professors and the plaintiffs' bar. These state court decisions are constitutionally valid, and they represent real opportunities for advocates of private enforcement and access to justice who believe they have been shut down in the Supreme Court. But, to the extent that we expect state courts to be vehicles for justice and enforcement, those courts must be proficient and available - and that takes effort and attention. The over-emphasis on federal courts may be obscuring something important.

That said, not all state court options are created equal. State court deviations on standing are the most insulated from erosion by federal decisions. ${ }^{268}$ State courts are free to confer standing more broadly than federal courts and apply broader state law standing doctrine to federal law claims. ${ }^{269}$ If defendants attempt to remove such claims to federal court, these cases will be remanded when federal standing does not exist, leaving state courts free to adjudicate the underlying issues. ${ }^{270}$ Thus, the Supreme Court's standing decisions in Spokeo, Lujan, and others - and perhaps its decisions on other aspects of justiciability ${ }^{271}$-are the broadest invitations to state courts. ${ }^{272}$

Decisions on the Federal Rules also do not apply in state courts, but state decisions on pleading, summary judgment, and class actions are only effective if cases remain in those state courts. ${ }^{273}$ And while plaintiffs select the initial forum, if defendants can remove cases to federal courts, then federal procedure will reign. ${ }^{274}$ Significantly, this is the alignment in many cases that attempt to enforce federal statutory rights, ${ }^{275}$ which would create federal question jurisdiction. ${ }^{276} \mathrm{~A}$ state legislature might obviate the need to plead a federal question by creating a state law cause of action, though an aggressive Supreme Court could find that federal law preempts the state law (thus leaving a federal question in place) ${ }^{277}$

267. See supra Parts III.A-D.

268. See infra Part II.B.

269. See infra Part II.B. Although state courts may confer standing more broadly than the federal courts, they may not be able to restrict standing for federal law claims. See, e.g., Testa v. Katt, 330 U.S. 386 (1947).

270. See supra Part III.C.

271. See supra note 204.

272. See Clopton, supra note 65 (exploring these invitations in more detail).

273. See supra Part II.A.

274. See 28 U.S.C. $§ 1441$ (2012). See generally EDWARD A. PURCELL, JR., LiTIGATION AND INEQUALITY: FEDERAL DIVERSITY JURISDICTION IN INDUSTRIAL AMERICA, 1870-1958, 13-27 (1992) (discussing the significance of removal for corporate defendants); Stephen B. Burbank, The Class Action Fairness Act of 2005 in Historical Context: A Preliminary View, 156 U. PA. L. REV. 1439, 1468-83 (2008) (connecting Purcell and CAFA).

275. Many, but not all - the Federal Employers' Liability Act, for example, limits removal of some claims originally filed in state court. See 28 U.S.C. $§ 1445$ (2012).

276. See 28 U.S.C. $\S 1331$ (2012) (federal questions). Indeed, federal statutory claims are the focus of Burbank and Farhang's work cited supra notes 19, 74.

277. See U.S. ConST. art. VI, cl. 2 (Supremacy Clause); see also Coleman, supra note 231, at 320-24 (collecting cases from the Roberts Court). Similarly, when Congress recently federalized the law of trade secret misappropriation, it impliedly gave defendants the option to elect federal court 
Congress also can undercut state procedural reform by making more cases removable to federal courts. ${ }^{278}$ For example, the Class Action Fairness Act (CAFA) sweeps more putative class actions into federal court. ${ }^{279}$ CAFA, it seems, was motivated in large part by state courts deviating from federal class action law-eerily familiar to the deviations described above. ${ }^{280}$ CAFA is particularly effective in this regard because it applies to putative class actions even if federal courts ultimately deny certification. ${ }^{281}$

State courts' attempts to deviate from arbitration law are the least effective. Arbitration was noticeably absent from this Section, and the reason is that the Court's arbitration jurisprudence derives from the Federal Arbitration Act (FAA), a federal statute with preemptive power over inconsistent state laws. ${ }^{282}$ Despite the persistent efforts of Justice Thomas, the Supreme Court has consistently held that the FAA applies in state courts. ${ }^{283}$ So while state courts could exhibit hostility to arbitration sotto voce-as Justice Scalia seemingly accused the California courts ${ }^{284}$ - they cannot use state law to escape the FAA. ${ }^{285}$

In sum, state courts have deviated from a range of federal procedural decisions, but those deviations vary in their ability to withstand removal and preemption. To put it another way, many of the Supreme Court's most devastating decisions for court access and private enforcement are linked to the work of Congress-e.g., federal statutes preempting state law, establishing

procedural law, when previously many of these cases remained in state court. See 18 U.S.C. $§ 1836$ (2012) (as amended by the Defend Trade Secrets Act of 2016).

278. See, e.g., supra note 41 (discussing Shady Grove). The same effect would result from statutes providing exclusive federal jurisdiction.

279. See Pub. L. No. 109-2, 119 Stat. 4 (2005) (codified in scattered sections of 28 U.S.C.) Indeed, federal courts routinely retain jurisdiction over cases removed under CAFA after denying class certification. See infra note 281. Note also that some federal procedural rules will apply in state court when federal substantive law is at issue. See supra note 106 (discussing "Reverse Erie").

280. See, e.g., Samuel Issacharoff \& Richard A. Nagareda, Class Settlements Under Attack, 156 U. PA. L. REV. 1649 (2008) (finding that CAFA supporters were motivated by concerns of the "anomalous" state court that would improperly certify a nationwide class).

281. See, e.g., Wright Transp., Inc. v. Pilot Corp., 841 F.3d 1266 (11th Cir. 2016) (retaining jurisdiction); Metz v. Unizan Bank, 649 F.3d 492, 500-01 (6th Cir. 2011) (same); Buetow v. A.L.S. Enters., Inc., 650 F.3d 1178, 1182 n.2 (8th Cir. 2011) (same); Cunningham Charter Corp. v. Learjet, Inc., 592 F.3d 805, 806-07 (7th Cir. 2010) (same); United Steel Int'l Union v. Shell Oil Co., 602 F.3d 1087, 1089 (9th Cir. 2010) (same); Vega v. T-Mobile USA, Inc., 564 F.3d 1256, 1268 n.12 (11th Cir. 2009) (same); see also Kevin M. Clermont, Jurisdictional Fact, 91 CORNELL L. REV. 973, 1015-17 (2006) (presaging this result).

282. 9 U.S.C. $\S \S 1-16$ (2012); see also supra notes 52-59 and accompanying text.

283. See, e.g., DIRECTV, Inc. v. Imburgia, 136 S. Ct. 463, 471 (2015) (Thomas, J., dissenting); Buckeye Check Cashing, Inc. v. Cardegna, 546 U.S. 440, 449 (2006) (Thomas, J., dissenting).

284. AT\&T Mobility LLC v. Concepcion, 563 U.S. 333, 342 (2011) (“[A]lthough these statistics are not definitive, it is worth noting that California's courts have been more likely to hold contracts to arbitrate unconscionable than other contracts.").

285. For a potential counterexample, see infra Part III (public enforcement). 
federal jurisdiction, or permitting removal. ${ }^{286}$ Though it is little solace to defeated plaintiffs to hear that they should divide their anger between at least two branches, this insight is important conceptually for understanding (and reforming) civil justice. ${ }^{287}$

III.

\section{Civil Procedure AND StATE ENFORCEMENT}

The previous Section outlined how state courts could deviate from federal approaches that seem to restrict private enforcement and access to justice. But courts are not the only actors. ${ }^{288}$ This Section looks to state public enforcement as a response to the Roberts Court's curtailment of private litigation, especially private aggregate litigation. ${ }^{289}$ The theme here is that, in many areas, public suits may be substitutes for private suits that are cutoff by federal procedure. By "substitutes," I do not mean perfect substitutes - as explored throughout, public enforcement may not exactly match displaced private enforcement with respect to remedies, compensation, or process. But public enforcement at least represents an imperfect substitute, lessening the blow from federal procedural retrenchment. ${ }^{290}$ And, in theory, the right state legislative and executive action could push public enforcement closer to substitutability. ${ }^{291}$

Before beginning this analysis, two caveats are in order. First, public enforcement is not limited to the states-federal agencies routinely enforce federal law, and many of the Roberts Court's procedural decisions leave open federal public enforcement as well. While I mention a few illustrative examples of federal enforcement in the forthcoming survey, the target of this Section remains state public enforcement. Second, as explained throughout, the "data" in this Section are more impressionistic than the state-by-state reviews above. But like that earlier analysis, this Section both explains the alternative pathways and offers examples of these alternatives in action. ${ }^{292}$

286. Another way to understand these conclusions is that retrenching judges or litigants might look for doctrines based in federal preemption or subject-matter jurisdiction to ensure against state deviations.

287. There also may be reasons to think differently about choices made by the Supreme Court and those made by Congress. See infra Conclusion.

288. A simple legislative solution would be for Congress to overrule by statute every offending, non-constitutional federal procedural decision. Cf. William N. Eskridge, Jr., Overriding Supreme Court Statutory Interpretation Decisions, 101 YALE L.J. 331 (1991) (cataloging cases overridden by Congress). There is not much to add to this possible but highly unlikely idea.

289. There is not much to say about political branch responses to decisions on pleading and summary judgment, other than to repeat that legislation could address these topics.

290. Public enforcement may be closer to a perfect substitute with respect to deterrence than compensation or due process. See infra notes 453-457 and accompanying text.

291. As explored throughout, public enforcement faces significant resource constraints, though there are legislative and enforcement tools available to leverage those resources to great effect.

292. Unlike state court rejection, using public enforcement to respond to federal procedural decisions requires a more thoroughgoing policy design, so this Section explores that design in some detail. 


\section{A. Class Action Substitutes}

As described above, the Roberts Court has seemingly made it more difficult to certify federal class actions. ${ }^{293}$ CAFA compounds this effect by making it easier to get putative class actions into federal court, and thus easier to evade state alternatives. ${ }^{294}$

Enter public enforcement. State executive enforcers may be able to fill the shoes of class action litigants while avoiding the requirements of Rule 23. State legislatures also may authorize "private attorneys general" to pursue public enforcement. ${ }^{295}$ This Section reviews these options at length, in part because this analytic work applies to many issues taken up in future Sections as well.

\section{Attorney General Suits}

The first potential intervention is direct government litigation. Government suits could take the form of traditional public enforcement, ${ }^{296}$ or they could look more like representational actions on behalf of state residents. ${ }^{297}$ For centuries, public actors have brought representational suits on behalf of their citizens (or subjects), often labeled "parens patriae" actions. ${ }^{298}$ Today, state attorneys general have parens patriae authority under numerous federal statutes and often under state law, ${ }^{299}$ and this authority frequently applies in common class action areas $^{300}$ such as securities, ${ }^{301}$ antitrust, ${ }^{302}$ employment, ${ }^{303}$ and consumer law. ${ }^{304}$

Importantly, public suits are not subject to certification under Federal Rule $23,{ }^{305}$ even if they are seeking remedies that private class actions could

293. See supra notes $41-45$ and accompanying text.

294. See supra note 279 and accompanying text.

295. One might object to referring to private attorneys general as "public" enforcement. See infra Part III.A.2. This label is useful for structuring the argument, but it is not analytically necessary. Either way, federal procedural decisions may not constrain such suits.

296. See, e.g., Margaret H. Lemos, State Enforcement of Federal Law, 86 N.Y.U. L. REV. 698 (2011) (collecting examples of state attorneys general enforcing federal statutes).

297. See, e.g., Alfred L. Snapp \& Son, Inc. v. Puerto Rico ex rel. Barez, 458 U.S. 592, 600-05 (1982) (parens patriae). See generally Margaret H. Lemos, Aggregate Litigation Goes Public: Representative Suits by State Attorneys General, 126 HARV. L. REV. 486 (2012).

298. Snapp, 458 U.S. at 600-05; Lemos, supra note 297, at 492-98. Although its technical meaning is narrower, the term parens patriae has been used to describe governmental actions that seek to vindicate private rights.

299. See Lemos, supra note 297, at 495-98 (collecting statutes).

300. See, e.g., Brian T. Fitzpatrick, An Empirical Study of Class Action Settlements and Their Fee Awards, 7 J. EMPIRICAL LEGAL STUD. 811 (2010) (identifying common subject matters for class action litigation); Theodore Eisenberg \& Geoffrey P. Miller, Attorney Fees in Class Action Settlements: An Empirical Study, 1 J. EMPIRICAL LEGAL STUD. 27 (2004) (same).

301. See, e.g., N.Y. GEN. BUS. LAW §§ 352-53 (McKinney 2016) (Martin Act).

302. See, e.g., 15 U.S.C. $\S 15$ c (2012) (Sherman Act).

303. Title VII, for example, expressly includes states. See 42 U.S.C. $\S \S 2000 \mathrm{e}-5(\mathrm{c}), 2000 \mathrm{e}-7$ (2012).

304. See, e.g., 15 U.S.C. § 2073(b) (2012) (providing state enforcement of federal consumer law).

305. Of course, states may require certification or other procedures for parens patriae suits. 
theoretically pursue. ${ }^{306}$ Indeed, some public-enforcement authorities were expressly adopted with class actions in mind. For example, the Second Circuit explained that "Congress empowered state attorneys general to investigate and prosecute antitrust abuses on behalf of consumers stymied by Rule 23's certification and notification hurdles. ${ }^{, 307}$ Moreover, the Supreme Court recently confirmed that parens patriae actions are not class actions, and therefore they fall outside the reach of CAFA. ${ }^{308}$ This means that more of these suits can remain in state court, insulated from federal procedure. ${ }^{309}$

In practice, there are many examples of parens patriae actions filed in parallel with class actions. Perhaps the most famous example involved state suits against tobacco companies, ${ }^{310}$ which proceeded despite various courts denying certification to private class actions. ${ }^{311}$ The tobacco cases are not alone. ${ }^{312}$ Indeed, in its opinion denying certification of a class action against H \& R Block, the Southern District of Georgia observed in dictum that "denial of certification does not, however, operate to preclude any state agency from initiating a state law parens patriae action." ${ }^{, 313}$ California later sued H \& R Block over the same program. ${ }^{314}$

306. See, e.g., Washington v. Chimei Innolux Corp., 659 F.3d 842, 848 (9th Cir. 2011) ("[T]he Attorneys General have statutory authority to sue in parens patriae and need not demonstrate standing through a representative injury nor obtain certification of a class in order to recover on behalf of individuals.").

307. New York ex rel. Vacco v. Reebok Int'l Ltd., 96 F.3d 44, 46 (2d Cir. 1996) (discussing HartScott-Rodino Antitrust Act); see H.R. Rep. No. 94-499, at 6-7 (1976). The Mississippi Attorney General also lobbied for greater parens patriae authority to make up for a lack of class action options under state law. See Mississippi ex rel. Hood v. AU Optronics Corp., 134 S. Ct. 736 (2014).

308. See Mississippi ex rel. Hood, 134 S. Ct. 736; Nevada v. Bank of Am. Corp., 672 F.3d 661, 667 (9th Cir. 2012) (holding that parens patriae actions are not removable as "class actions" under CAFA).

309. For examples of state public actions remanded to state courts on this basis, see Hawai'i ex rel. Louie v. HSBC Bank Nev., 761 F.3d 1027 (9th Cir. 2014); In re Standard \& Poor's Rating Agency Litig., 23 F. Supp. 3d 378 (S.D.N.Y. 2014); Louisiana v. Zealandia Holding Co., Inc., No. 13-6724, 2014 WL 1378874 (E.D. La. Apr. 8, 2014); West Virginia ex rel. McGraw v. Bristol-Myers Squibb Co., No. 13-1603 (FLW), 2014 WL 793569 (D.N.J. Feb. 26, 2014).

310. See generally RiCHARD A. NAGAREDA, MASS TORTS IN A WORLD OF SETTLEMENT (2007) (discussing tobacco litigation); Richard P. Ieyoub \& Theodore Eisenberg, State Attorney General Actions, the Tobacco Litigation, and the Doctrine of Parens Patriae, 74 TUL. L. REV. 1859 (2000) (same).

311. See, e.g., Cosentino v. Philip Morris Inc., No. Civ.A. MDL-L-5135-97, 1998 WL 34168879 (N.J. Super. Ct. Oct. 22, 1998) (remanded to state court after finding lack of jurisdiction).

312. See, e.g., Samuel Issacharoff \& D. Theodore Rave, The BP Oil Spill Settlement and the Paradox of Public Litigation, 74 LA. L. REV. 397 (2014) (discussing private and public suits against BP). In some circumstances, courts have denied class certification because parallel public suits were "superior" under Rule 23(b)(3)). See, e.g., Kamm v. Cal. City Dev. Co., 509 F.2d 205, 213 (9th Cir. 1975 ) (finding no abuse of discretion in dismissing class action when class is adequately represented by the Attorney General); Pennsylvania v. Budget Fuel Oil Co., 122 F.R.D. 184, 185-86 (E.D. Pa. 1988) (denying class certification because parens patriae action deemed superior). Maryland so provided by statute. See MD. CODE ANN., COM. LAW § 11-209(c) (West 2017).

313. Buford v. H \& R Block, Inc., 168 F.R.D. 340, 364 (S.D. Ga. 1996).

314. See California v. H \& R Block, Inc., No. C 06-2058 SC, 2006 WL 2669045 (N.D. Cal. Sept. 18,2006 ) (remanding government suit to state court). 
The H \& R Block experience is suggestive of a strategy by which state agencies could look to decisions denying class certification as a potential trigger for public enforcement. Certification denials might signal good cases, ${ }^{315}$ as class counsel presumably would not have invested resources in a putative class action-especially one with suspect chances at certification - unless there was something to the merits of the complaint. ${ }^{316}$ Moreover, public actors stepping into cases midstream may benefit from the efforts undertaken by private parties before certification was denied. ${ }^{317}$ In short, this version of "tagalong" public enforcement could make up for federal courts undermining private enforcement. ${ }^{318}$

The aforementioned California suit against H \& R Block resembles this suggested strategy - a public suit following the denial of class certification. ${ }^{319}$ An illustrative federal example is the recent employment litigation against Cintas Corporation. ${ }^{320}$ In that case, the Equal Employment Opportunity Commission (EEOC) intervened in an ongoing class action but essentially sat out of the litigation. ${ }^{321}$ That is, until the federal court denied class certification, at which point the EEOC took the reins. ${ }^{322}$ The EEOC ultimately settled this case on behalf of the putative class. ${ }^{323}$ In other words, a public agency substituted for private enforcement once class certification was denied. ${ }^{324}$

Agencies also could look to class settlements for potential cases. Much has been written about the potential for class settlements to undercompensate and under-deter, ${ }^{325}$ and the tightening of certification rules should reduce the

315. See Zachary D. Clopton, Redundant Public-Private Enforcement, 69 VAND. L. REV. 285 (2016) (discussing public-private signaling) [hereinafter Clopton, Redundant Enforcement].

316. Indeed, the investment of resources may be a clearer signal than filing a complaint with an agency or seeking a whistleblower award. See generally Anthony J. Casey \& Anthony Niblett, Noise Reduction: The Screening Value of Qui Tam, 91 WASH. U. L. REV. 1169 (2014).

317. Rule 23(c)(1)(A) directs courts to decide certification "at an early practicable time," but at a minimum these decisions occur after plaintiffs' preparation and filing of a complaint.

318. See Clopton, Redundant Enforcement, supra note 315, at 318-24.

319. See supra note 314 and accompanying text.

320. See EEOC v. Cintas Corp., Nos. 04-40132, 06-12311, 2011 WL 3359622 (E.D. Mich. Aug. 4, 2011).

321. Id. at *1-2.

322. Id.

323. See Press Release, EEOC, Cintas Corporation to Pay $\$ 1.5$ Million to Settle EEOC Class Sex Discrimination Lawsuit, https://www.eeoc.gov/eeoc/newsroom/release/11-30-15.cfm [https://perma.cc/4YRP-JTHD].

324. One might wonder whether the statute of limitations would limit this strategy. In certain circumstances, the filing of a class action tolls the statute of limitations for individual claims. See Am. Pipe \& Constr. Co. v. Utah, 414 U.S. 538 (1974). New York State argued that American Pipe tolling also should apply to public representational actions. Plaintiff's Opposition to Defendant's Motion for Partial Summary Judgment on Statute of Limitations Grounds at *7-16, New York v. Intel Corp., No. 09-827 (LPS), 2011 WL 3360366 (D. Del. Aug. 3, 2011). The District of Delaware ruled against New York but did not altogether reject this argument. See New York ex rel. Schneiderman v. Intel Corp., Civ. No. 09-827-LPS, 2011 WL 6100408 (D. Del. Dec. 7, 2011).

325. See generally Alexandra D. Lahav, Symmetry and Class Action Litigation, 60 UCLA L. REV. 1494 (2013). Cy pres settlements have received particularly harsh treatment in the literature. 
expected value of class litigation. ${ }^{326}$ If state attorneys general believe that Rule 23 is reducing the value of class settlements, then they might look to those settlements as triggers for public litigation. ${ }^{327}$ Under CAFA, state attorneys general are notified of class settlements involving their residents. ${ }^{328}$ States may respond to these notices by formally objecting to the settlement, ${ }^{329}$ but states also could respond with public suits of their own. ${ }^{330}$

This is exactly what happened with respect to claims of false advertising and unfair competition against IntelliGender, the maker of a fetal gender prediction test. ${ }^{331}$ Pursuant to a class settlement, IntelliGender agreed to pay $\$ 10$ to each class member who received an inaccurate gender prediction ${ }^{332}$ and to make a cy pres donation of $\$ 40,000$ worth of product. ${ }^{333}$ Dissatisfied with the outcome, the California Attorney General brought suit on the same claims, and the Ninth Circuit held that the state could pursue civil penalties and injunctive relief on behalf of residents regardless of the class settlement. ${ }^{334}$ Similarly, despite a multibillion-dollar class settlement, New York and Massachusetts recently filed suit in New York state court seeking penalties from Volkswagen and its leaders for its emissions deception. ${ }^{335}$

The foregoing suggestions relied on certification denials or settlements to signal public enforcement, but public enforcers also could respond with more generalized policies to identify suitable cases for public enforcement. State

326. See, e.g., id. at 1498-99 (observing that more onerous requirements for the certification of litigation classes as compared with settlement classes may reduce settlement values); Zachary D. Clopton, Transnational Class Actions in the Shadow of Preclusion, 90 IND. L.J. 1387, 1409-10 (2015) (applying this logic to transnational class actions in which certification may be denied).

327. See Clopton, Redundant Enforcement, supra note 315. Professor Howard Erichson has identified "red flags" in class settlements. Howard M. Erichson, Aggregation as Disempowerment: Red Flags in Class Action Settlements, 92 NOTRE DAME L. REV. 859 (2016). Erichson suggests these red flags are relevant to professional responsibility, and this Article suggests they might be signals to public enforcers too.

328. 28 U.S.C. $§ 1715$ (b) (2012). See generally Catherine M. Sharkey, CAFA Settlement Notice Provision: Optimal Regulatory Policy?, 156 U. PA. L. REV. 1971 (2008) (discussing CAFA notice).

329. See, e.g., Brief Amicus Curiae of the Attorneys General of Alaska et al. in Opposition to the Proposed Settlement Agreement, Figueroa v. Sharper Image Corp., 517 F. Supp. 2d 1292 (S.D. Fla. 2007) (No. 05-21251-CIV); see also Sharkey, supra note 328, at 1989 (citing aforementioned brief).

330. For example, public enforcers might scrutinize class settlements for unusual terms that risk under-deterrence. See supra note 327.

331. California v. IntelliGender, LLC, 771 F.3d 1169 (9th Cir. 2014).

332. The product itself cost \$29.95. See Appellee's Opening Brief at 9, California v. IntelliGender, LLC, 771 F.3d 1169 (9th Cir. 2014) (No. 13-56806).

333. See IntelliGender, 771 F.3d at 1175 (discussing Gram v. IntelliGender, No. 2:10-CV-04210 (C.D. Cal. filed June 7, 2010)). It does not appear that "product" refers to gender-prediction tests, though the exact product is not specified. See Brief of Appellee at Exhibit 1, California v. IntelliGender, LLC, 771 F.3d 1169 (9th Cir. 2014) (No. 13-56806).

334. 771 F.3d at 1175-78. Note, however, that California could not pursue pure compensatory relief on behalf of residents. Id. at 1179-82.

335. See, e.g., Jack Ewing \& Hiroko Tabuchi, Volkswagen Scandal Reaches All the Way to the Top, Lawsuits Say, N.Y. TIMES (July 19, 2016), https://nyti.ms/2adp7h0 [https://perma.cc/ZK6YD3U5]. 
enforcers might decide that the difficulty of bringing a private class action should be a factor in favor of exercising their enforcement discretion. For example, imagine that the federal courts made it more difficult to bring a particular type of class action-perhaps class actions alleging that "local managers' discretion over pay and promotions is exercised disproportionately in favor of men, leading to an unlawful disparate impact." ${ }^{, 36}$ State agencies might decide to target resources to claims of this type. Although agencies are often reluctant to publicize enforcement priorities, there is reason to suspect that public agencies consider the efficacy of private relief when making enforcement choices. ${ }^{337}$ Indeed, it would not be at all surprising for a government enforcer to allocate public resources in light of private capabilities. ${ }^{338}$

\section{Private Attorney General Suits}

The previous Section suggested that state enforcers could fill gaps created by restrictive interpretations of the Federal Rules. This analysis assumed that public resources were available or could be shifted among priorities. But public resources are scarce, and indeed, resource constraints were an animating purpose of the private-enforcement revolution. ${ }^{339}$ Professors Gilles and Friedman suggested that states hire private firms on contingency to pursue similar goals without public resources. ${ }^{340}$ Another option looks to private attorneys general. "Private attorney general" is a capacious and contested term. ${ }^{341}$ I use it here to refer to a limited set of actions, exemplified by California's Private Attorney General Act (PAGA), which comprises another potential response to federal procedural limits. ${ }^{342}$

In 2003, the California legislature adopted PAGA to permit private enforcement of various provisions of the State's labor law. ${ }^{343}$ The private

336. Wal-Mart Stores, Inc. v. Dukes, 564 U.S. 338, 344 (2011).

337. For example, Urska Velikonja showed that the U.S. Securities and Exchange Commission (SEC) is particularly interested in types of enforcement cases that are difficult for private parties to win. See Urska Velikonja, Public Compensation for Private Harm: Evidence from the SEC's Fair Fund Distributions, 67 STAN. L. REV. 331 (2015) (discussing an SEC role in cases against investment advisors, broker-dealers, and investment banks).

338. For a collection of sources (and a model of institutional design), see generally Clopton, Redundant Enforcement, supra note 315, at 314-17.

339. See, e.g., Clopton, Redundant Enforcement, supra note 315, at 315. For example, providing attorney fees or other incentives could encourage private enforcement even for negative-value claims. See, e.g., FARHANG, supra note 14, at 21-31; Margaret H. Lemos, Special Incentives to Sue, 95 MinN. L. REV. 782 (2011) (surveying mechanisms to encourage private enforcement).

340. See Myriam Gilles \& Gary Friedman, After Class: Aggregate Litigation in the Wake of AT\&T Mobility v Concepcion, 79 U. CHI. L. REV. 623, 669 (2012); see also Margaret H. Lemos \& Max Minzner, For-Profit Public Enforcement, 127 HARV. L. REV. 853, 864-75 (2014) (discussing "revolving funds" and other options for public enforcement in light of budget constraints).

341. See, e.g., Clopton, Redundant Enforcement, supra note 315, at 288 (collecting sources).

342. CAL. LAB. CODE $\S \S 2698-2699.5$ (West 2017). See generally Janet Cooper Alexander, To Skin a Cat: Qui Tam Actions as a State Legislative Response to Concepcion, 46 U. MICH. J.L. REFORM 1203 (2013) (discussing PAGA).

343. See 2003 Cal. Legis. Serv. 906 (S.B.796, § 2); CAL. LAB. CODE §§ 2698-2699.5. 
attorney general basically stands in the shoes of the state enforcement agency. ${ }^{344}$ According to a State Senate Committee analysis: "Arguably, in a perfect world, there would be no need for the right to act as [private attorney general], yet the fact remains that due to continuing budgetary and staffing constraints, full, appropriate and adequate Labor Code enforcement is unrealizable if done solely by the Agency." ${ }^{345}$ Under PAGA, employees supplement public enforcement by suing on behalf of current and former employees, and civil penalties may be distributed to aggrieved employees. ${ }^{346}$ Hundreds of reported cases have invoked PAGA seeking millions of dollars in recoveries. ${ }^{347}$

Although a PAGA suit on behalf of employees sounds a lot like a class action, courts have consistently held that it is not treated as one. ${ }^{348}$ State and federal courts regularly permit PAGA actions on behalf of aggrieved employees without class certification. ${ }^{349}$ Moreover, the Ninth Circuit held that PAGA suits (like parens patriae actions ${ }^{350}$ ) may not be removed under CAFA, thus insulating them from federal procedure more generally. ${ }^{351}$

Responding to federal class action decisions, plaintiffs could file PAGA actions when class certification is denied or unlikely. Indeed, because a putative class representative could also be a PAGA plaintiff, plaintiffs could plead class and PAGA allegations in the alternative. For example, in 2011 Aladdin Zackaria filed a wage-and-hour suit on behalf of himself and current and former employees of none other than Wal-Mart. ${ }^{352}$ Zackaria pleaded his claims as both a class action and a PAGA suit. ${ }^{353}$ Wal-Mart opposed the motion for class certification, relying in large part on Wal-Mart v. Dukes. ${ }^{354}$ The district court agreed that class certification would be improper but permitted Zackaria to

344. See CAL. LAB. CODE $\S 2699$.

345. Bill Analysis, S.B. 796, Senate Comm. on Labor and Indus. Relations, 2003-2004 Reg. Sess., at 5 (2003).

346. Section 2699(i) provides: "75 percent to the Labor and Workforce Development Agency for enforcement of labor laws ... and ... education of employers and employees about their rights and responsibilities under this code, to be continuously appropriated to supplement and not supplant the funding to the agency for those purposes; and 25 percent to the aggrieved employees." CAL. LAB. CODE $\S 2699$ (i) (West 2017).

347. Janet Alexander observed that PAGA recoveries underperform class actions where available. See Alexander, supra note 342, at 1237.

348. See, e.g., Gallardo v. AT\&T Mobility, LLC, 937 F. Supp. 2d 1128, 1137 (N.D. Cal. 2013) (collecting cases). The 2014 Baumann decision, discussed infra note 351, gives even more reason to think that PAGA actions should not require certification. See Zackaria v. Wal-Mart Stores, Inc., 142 F. Supp. 3d 949 (C.D. Cal. 2015) (making this argument).

349. See Gallardo, 937 F. Supp. 2 d at 1137 (collecting cases); Zackaria, 142 F. Supp. 3d at 954 55 (collecting cases).

350. See supra notes 298-311 and accompanying text.

351. See Baumann v. Chase Inv. Servs. Corp., 747 F.3d 1117 (9th Cir. 2014). Removability also might be unavailable due to lack of federal standing. See infra Part III.C.

352. See Zackaria, 142 F. Supp. 3d at 951.

353. Id. at $951-52$.

354. Joint Brief Re: Plaintiff's Renewed Motion for Class Certification at 27-28, 48, Zackaria v. Wal-Mart Stores, Inc., 2014 WL 4954572 (C.D. Cal. May 29, 2014) (No. 5:12-cv-01520-FMO-SP). 
maintain his PAGA claim. ${ }^{355}$ The case ultimately settled, and it is hard to imagine that Zackaria would have achieved the same recovery had he been left only with his individual claim following the denial of class certification. ${ }^{356}$

PAGA is perhaps the clearest example of a private attorney general statute, but it is not the only one. Qui tam provisions, common in false claims acts, ${ }^{357}$ are essentially PAGAs. ${ }^{358}$ The District of Columbia permits, ${ }^{359}$ and California used to permit, ${ }^{360}$ private attorney general enforcement for some consumer laws. ${ }^{361}$ These examples highlight the potential flexibility of private attorney general acts. Statutes can be targeted to issue areas, like California's focus on labor and consumer law. ${ }^{362}$ They can operate as part of a more complex web of enforcement mechanisms: the federal False Claims Act and California's PAGA permit the government to take over enforcement, ${ }^{363}$ and some of these statutes provide notice and intervention rights to private parties as well. ${ }^{364}$ When such statutes include provisions for statutory damages ${ }^{365}$ or civil penalties $^{366}$ (as they

355. See Zackaria, 142 F. Supp. 3d at 952-60; Order Re: Motion for Class Certification, Zackaria v. Wal-Mart Stores, Inc., No. ED CV 12-1520 FMO (SPx), 2015 WL 2412103 (C.D. Cal. May 18, 2015).

356. See supra note 326 (discussing settlement values).

357. See, e.g., 31 U.S.C. $\S \S 3729-3733$ (2012) (federal False Claims Act); CAL. Gov’T CODE $\S \S$ 12650-12656 (West 2017); DEL. CODE ANN. tit. 6, §§ 1201-1211 (2017); 740 ILL. COMP. STAT. 175/18 (2017). See generally David Freeman Engstrom, Agencies as Litigation Gatekeepers, 123 YALE L.J. 616 (2013) (discussing qui tam provisions).

358. See Alexander, supra note 342, at 1221-26.

359. D.C. CODE $\S 28-3905(\mathrm{k})(1)(\mathrm{D})$ (2017) (allowing public interest suits on behalf of consumers); see, e.g., Nat'l Consumers League v. Bimbo Bakeries USA, 46 F. Supp. 3d 64 (D.D.C. 2014).

360. Trevor W. Morrison, Private Attorneys General and the First Amendment, 103 MicH. L. REV. 589, 605-06 (2005) (discussing California's now-repealed unfair-competition law).

361. So-called "citizen suit" provisions also exist and are common in environmental statutes. See Clopton, Redundant Enforcement, supra note 315, at 294 (collecting sources). But these provisions typically do not authorize compensatory damages, and they require certification when used in class actions.

362. See supra notes 342-347 and accompanying text.

363. See 31 U.S.C. $\S 3730$ (2012) (False Claims Act); CAL. LAB. CODE $\S 2699.3$ (West 2017) (PAGA).

364. See Clopton, Redundant Enforcement, supra note 315, at 304-05 (discussing notice and intervention in various statutory schemes that allow overlapping public and private enforcement). A legislature also could prioritize among enforcement types: the private attorney general statute could provide that such an action would only be permissible if superior alternatives were unavailable. $C f$. FED. R. CIV. P. 23(b)(3); see also supra note 312 (collecting cases in which courts found public enforcement superior to a class action).

365. See St. Louis, Iron Mountain \& S. Ry. Co. v. Williams, 251 U.S. 63 (1919) (an award of statutory damages satisfies due process); Browning-Ferris Indus. of Vt., Inc., v. Kelco Disposal, Inc., 492 U.S. 257, 276 (1989) (citing Williams).

366. See United States v. Bajakajian, 524 U.S. 321 (1998) (applying Excessive Fines Clause of the Eight Amendment). See generally Colleen P. Murphy, Reviewing Congressionally Created Remedies for Excessiveness, 73 OHIO ST. L.J. 651 (2012) (discussing various species of constitutional review of congressionally created remedies). 
often $\mathrm{do}^{367}$ ), then they seemingly should face weaker remedial scrutiny than analogous suits seeking punitive damages. ${ }^{368}$

Despite recent federal court decisions cutting back on class actions, there has not been a boom in PAGAs across the country. Indeed, California has eliminated private attorney general enforcement of its consumer laws, ${ }^{369}$ and it added new limits on PAGA labor actions. ${ }^{370}$ Perhaps the infrequency of PAGAs shows a lack of imagination from policymakers, but more likely it reflects some combination of a lack of appetite for increased enforcement and some unease with this unusual procedural form. ${ }^{371}$

To review, the Supreme Court's class action jurisprudence has made it more difficult for private parties to maintain class actions and thus has undercut private enforcement as a regulatory tool. State courts need not follow their federal counterparts, but CAFA's inclusion of even putative class actions make this at best an incomplete response. ${ }^{372}$ If state executives are worried about the effect that class action rules have on enforcement, they might consider allocating resources to cases that are denied certification or case types that are difficult to certify. ${ }^{373}$ States also could achieve similar effects through private attorney general acts. ${ }^{374}$ These acts will require legislative action, which to date has been in short supply, but they remain available for interested legislatures.

\section{B. Arbitration Substitutes}

A second line of procedural jurisprudence relates to arbitration. ${ }^{375}$ Obvious responses to these decisions would take the form of congressional action or authorized federal rulemaking. Indeed, Congress has considered bills to amend the FAA, ${ }^{376}$ and the Consumer Financial Protection Bureau adopted a sinceoverturned rule regulating certain arbitration clauses in consumer contracts. ${ }^{377}$

367. See, e.g., 31 U.S.C. $\S 3729$ (2012) (False Claims Act); CAL. LAB. CODE $§ 2699$ (f) (West 2017) (PAGA).

368. See Phillip Morris USA v. Williams, 549 U.S. 346, 355 (2007) (holding that punitive damages award based on a desire to punish for harming nonparties violates due process); BMW of $\mathrm{N}$. Am., Inc. v. Gore, 517 U.S. 559, 568, 572 (1996) (same). For decisions declining to apply the punitive damages standards to statutory penalties, see, for example, Sony BMG Music Entm't v. Tenenbaum, 719 F.3d 67 (1st Cir. 2013); Capitol Records, Inc. v. Thomas-Rasset, 692 F.3d 899 (8th Cir. 2012); Zomba Enters., Inc. v. Panorama Records, Inc., 491 F.3d 574 (6th Cir. 2007). There is much more to say about this idea, but this is not the place to say it.

369. See Morrison, supra note 360.

370. See supra note 346.

371. See infra Part IV.B (discussing the politics of enforcement).

372. See supra note 279.

373. See supra Part III.A.1.

374. See supra Part III.A.2.

375. See supra notes 52-58 and accompanying text.

376. See Alexander, supra note 342, at 1209-13 (citing proposed Arbitration Fairness Act, Fair Arbitration Act, and Consumer Mobile Fairness Act).

377. Arbitration Agreements, 81 Fed. Reg. 32,830 (May 24, 2016) (to be codified at 12 C.F.R. pt. 1040) [hereinafter "Final Rule"]. But see Providing for Congressional Disapproval Under Chapter 8 of Title 5, United States Code, of the Rule Submitted by Bureau of Consumer Financial Protection 
Of more interest here, public enforcement and private attorney general suits could counteract the Supreme Court's arbitration decisions as well. ${ }^{378}$

First, when government agencies and private attorneys general are not parties to arbitration agreements, ${ }^{379}$ those agreements presumably do not constrain their actions. ${ }^{380}$ Numerous state and federal courts (including the US Supreme Court ${ }^{381}$ ) have permitted public enforcement in the face of private arbitration agreements, ${ }^{382}$ and at least one federal court of appeals justified a proarbitration decision because the state attorney general could step in if private arbitration proved ineffective. ${ }^{383}$ It seems unlikely that arbitration clauses would bar third parties from suing to enforce public laws that happen to touch on contractual relationships involving arbitration clauses. To take an admittedly absurd example, it would be strange if a court held that a defendant insulated itself from a Clean Air Act suit brought by the state attorney general or by an environmental nonprofit because the polluter included an arbitration clause in its contract with the smoke-stack manufacturer. ${ }^{384}$ Similarly, when the National Consumer League (or the D.C. Attorney General) files a public-interest suit under local unfair-competition law, ${ }^{385}$ the presence of arbitration language in the consumer contract seems beside the point. ${ }^{386}$

Relating to "Arbitration Agreements," H.R.J. Res. 111, 115th Cong. (2017); 5 U.S.C. $\S \S 801-808$ (2012) (Congressional Review Act). See also Rhonda Wasserman, Legal Process in a Box, or What Class Action Waivers Teach Us About Law-Making, 44 LOY. U. CHI. L.J. 391 (2012) (discussing other regulatory options); Zachary D. Clopton, Class Actions and Executive Power, 92 N.Y.U L. REV. 878, 885-87 (2017) (collecting federal examples).

378. Professors Gilles and Friedman also looked to public enforcement after Concepcion. See supra note 340

379. See, e.g., Am. Express Co. v. Italian Colors, 133 S. Ct. 2304, 2309 (2013) ("[The FAA] reflects the overarching principle that arbitration is a matter of contract.").

380. As explained below, for various reasons it seems that standing should not represent an insurmountable obstacle to these suits either. See infra Part III.C.

381. See EEOC v. Waffle House, 534 U.S. 279, 293-96 (2002) (holding that the EEOC was not required to arbitrate disability-discrimination claim despite arbitration clause, even when the EEOC sought victim-specific relief).

382. See, e.g., Rent-A-Center, Inc. v. Iowa Civil Rights Comm'n, 843 N.W.2d 727 (Iowa 2014) (holding that the state was not required to arbitrate employment claim despite private arbitration clause); Joulé, Inc. v. Simmons, 459 Mass. 88, 944 N.E.2d 143, 149 (Mass. 2011) (same); State ex rel. Hatch v. Cross Country Bank, Inc., 703 N.W.2d 562 (Minn. Ct. App. 2005) (same for invasion-of-privacy claims); People ex rel. Cuomo v. Coventry First LLC, 915 N.E.2d 616 (N.Y. 2009) (same for claims of fraud and anticompetitive conduct). The occasionally cited counterexample, Olde Disc. Corp. v. Tupman, found Delaware's special administrative proceeding for securities claims to be an obstacle to the FAA, though this case involved an agency pursuing a remedy for a single claimant at the claimant's behest. 1 F.3d 202 (3d Cir. 1993).

383. See Iberia Credit Bureau v. Cingular Wireless LLC, 379 F.3d 159, 174-75 (5th Cir. 2004).

384. See 42 U.S.C $§ 7604$ (2012) (authorizing Clean Air Act citizen suits by "any person").

385. Cf. Nat'l Consumers League v. Bimbo Bakeries USA, 46 F. Supp. $3 d 64$ (D.D.C. 2014) (suing under D.C. CODE $\S 28-3905(\mathrm{k})(1)(\mathrm{D})$ ). The NCL is a nonprofit organization based in Washington, D.C.

386. One potential limit on this strategy would be courts prudentially staying (or dismissing) public enforcement actions pending private arbitration. In a recent case, the Eastern District of Louisiana refused to preempt an EEOC lawsuit alleging transgender discrimination because of an underlying 
The foregoing analysis focused on contract nonparties, but of course contractual employees are potential PAGA plaintiffs too. Recognizing this fact, some employers have expressly included PAGA among those claims to which arbitration agreements apply. ${ }^{387}$ However, California courts have found that PAGA waivers in arbitration clauses are unconscionable, ${ }^{388}$ and, contrary to current law on class waivers, ${ }^{389}$ the California Supreme Court and the Ninth Circuit have held that the FAA does not preempt these PAGA-unconscionability decisions. ${ }^{390}$ The Ninth Circuit reached this conclusion because PAGA actions are, essentially, public enforcement in private hands: "a PAGA action is a statutory action for penalties brought as a proxy for the state, rather than a procedure for resolving the claims of other employees . . .."391 That said, the Supreme Court has not always cottoned to Ninth Circuit arbitration decisions, ${ }^{392}$ and other federal courts have begun to compel arbitration of qui tam suits. ${ }^{393}$ PAGA non-preemption thus may not last - though the aforementioned suits by contract nonparties are on stronger footing. ${ }^{394}$

Assuming that state actors or private attorneys general were able to sue, their efforts could target cases involving arbitration clauses through various mechanisms. Public or private parties could scrutinize cases in which courts compel arbitration, particularly arbitration without access to class procedures. ${ }^{395}$ More aggressively, agencies could direct enforcement resources toward entities that include arbitration agreements in their contracts. Imagine that the Attorney General of Vermont were to conclude that arbitration unduly interfered with the State's consumer laws. The AG could announce that, as a matter of prosecutorial discretion, the department will focus its investigative resources on entities that

arbitration clause, but (unusually) it stayed the public litigation pending the outcome of the private arbitration. See Broussard v. First Tower Loan, LLC, No. 15-CV-1161, 2016 WL 879995 (E.D. La. Mar. 8, 2016) (denying motion to reconsider order staying the EEOC's claims); Broussard v. First Tower Loan, LLC, 135 F. Supp. 3d 540 (E.D. La. 2015); Broussard v. First Tower Loan, LLC, 150 F. Supp. 3d 709 (E.D. La. 2015) (granting motion to stay EEOC claims pending arbitration).

387. See, e.g., Sakkab v. Luxottica Retail N. Am., Inc., 803 F.3d 425 (9th Cir. 2015) (holding that the FAA did not preempt California rule barring waivers of representative PAGA claims); Brown v. Ralphs Grocery Co., 197 Cal. App: 4th 489, 503 (2011) (same); see also Alexander, supra note 342, at 1230 (making a similar observation).

388. Iskanian v. CLS Transp. L.A., LLC, 327 P.3d 129 (Cal. 2014).

389. See supra notes $57-58$ (citing cases).

390. See Sakkab, 803 F.3d at 436; Brown, 197 Cal. App. 4th at 503.

391. Sakkab, 803 F.3d at 436; see also Alexander, supra note 342, at 1232-33 (making a similar observation).

392. See, e.g., AT\&T Mobility LLC v. Concepcion, 563 U.S. 333 (2011); Rent-A-Center, W., Inc. v. Jackson, 561 U.S. 63 (2010).

393. See Deck v. Miami Jacobs Bus. Coll. Co., No. 3:12-cv-63, 2013 WL 394875, at *8 (S.D. Ohio Jan. 31, 2013) (compelling arbitration of qui tam claims under the False Claims Act); see also United States ex rel. Wilson v. Kellogg Brown \& Root, Inc., 525 F.3d 370, 381 (4th Cir. 2008) (collecting False Claims Act retaliation cases). Some federal court cases prior to Sakkab reached a similar conclusion on PAGA. See, e.g., Cunningham v. Leslie's Poolmart, Inc., No. CV 13-2122 CAS (CWx), 2013 WL 3233211, at *37 (C.D. Cal. June 25, 2013) (compelling arbitration of PAGA claim).

394. See supra notes 379-386 and accompanying text (discussing these suits).

395. See supra notes $57-58$ and accompanying text. 
include arbitration clauses in consumer contracts because arbitration undermines deterrence as compared with private litigation. ${ }^{396}$

Although the Supreme Court has been quick to find FAA preemption, ${ }^{397}$ there are reasons to think that the FAA may not preempt this policy. For one thing, the Supreme Court has said that the "principal purpose of the FAA is to ensur[e] that private arbitration agreements are enforced according to their terms." ${ }^{398}$ Nothing about this policy would have any effect on the enforceability of arbitration agreements according to their terms. ${ }^{399}$ In other places, the Supreme Court has explained the FAA's purpose was "to reverse the longstanding judicial hostility to arbitration agreements ... and to place arbitration agreements upon the same footing as other contracts." ${ }^{\text {"400 }}$ Permitting public enforcement has no bearing on judicial hostility, nor would public enforcement affect arbitration's equal legal footing. ${ }^{401}$ In addition, prosecutorial discretion is an area of strong deference to executive actors, so the burden on the preemption argument would be quite high. ${ }^{402}$ And, it is not as if a hypothetical state attorney general would announce a policy of disfavoring arbitration for arbitration's sake-the proposed policy aims at ineffective private enforcement. ${ }^{403}$ Indeed, if the true culprit were the waiver of aggregate procedures, ${ }^{404}$ then this policy could apply to class action waivers without accompanying arbitration clauses as well. ${ }^{40}$

396. See, e.g., CONSUMER FIN. PROT. BUREAU, ARBITRATION STUDY: REPORT TO CONGRESS, PURSUANT TO DODD-FRANK WALL STREET REFORM AND CONSUMER PROTECTION ACT § 1028(A), (2015) [hereinafter “CFPB STUDY”].

397. See supra notes 55, 57 (citing cases).

398. AT\&T Mobility LLC v. Concepcion, 563 U.S. 333, 344 (2011) (internal quotation marks omitted).

399. Again, a state would not be a contract party. See supra notes 379-386 and accompanying text

400. Gilmer v. Interstate/Johnson Lane Corp., 500 U.S. 20, 24 (1991).

401. The Supreme Court also has been wary of state contract doctrines that disfavor arbitration as applied. See Concepcion, 563 U.S. at 341 ("[T] normally thought to be generally applicable, such as duress or, as relevant here, unconscionability, is alleged to have been applied in a fashion that disfavors arbitration."). But notably its examples were doctrines applied to proceedings between parties to the arbitration clause - there was no discussion of proceedings involving a contract nonparty. See id. (discussing this case and Perry v. Thomas, 482 U.S. $483(1987))$.

402. See, e.g., Bond v. United States, 134 S. Ct. 2077, 2092-93 (2014) (“[W]e have traditionally viewed the exercise of state officials' prosecutorial discretion as a valuable feature of our constitutional system ... . Prosecutorial discretion involves carefully weighing the benefits of a prosecution against the evidence needed to convict, the resources of the public fisc, and the public policy of the State.").

403. Such a policy could target other forms of "procedural contracting" that also undermine private enforcement. See generally Robert G. Bone, Party Rulemaking: Making Procedural Rules Through Party Choice, 90 TEX. L. REV. 1329 (2012). For example, consider fee-shifting and other litigation-related provisions in corporate bylaws and charters. See, e.g., David Skeel, The Bylaw Puzzle in Delaware Corporate Law, 72 Bus. LAW. 1 (2017); Verity Winship, Shareholder Litigation by Contract, 96 B.U. L. REV. 485 (2016).

404. See supra notes 57-58 and accompanying text.

405. Interestingly, the Sixth Circuit held that Fair Labor Standards Act collective-action waivers are unenforceable unless they come with an arbitration agreement. Killion v. KeHE Distribs., LLC, 761 
There is little evidence of any agency formally adopting such a policy targeting arbitration, though agencies often remain opaque with respect to enforcement discretion. ${ }^{406}$ That said, state and federal enforcement agencies have not been quiet with respect to arbitration. The EEOC issued the following instructions regarding potential enforcement suits:

Charges should be taken and processed in conformity with priority charge processing procedures regardless of whether the charging party has agreed to arbitrate employment disputes. Field offices are instructed to closely scrutinize each charge involving an arbitration agreement to determine whether the agreement was secured under coercive circumstances (e.g., as a condition of employment). The [EEOC] will process a charge and bring suit, in appropriate cases, notwithstanding the charging party's agreement to arbitrate. ${ }^{407}$

Consistent with these instructions, ${ }^{408}$ the EEOC routinely litigates against the backdrop of arbitration clauses. ${ }^{409}$ At the same time, the Consumer Financial Protection Bureau (CFPB) has repeatedly expressed concern about arbitration in consumer disputes; ${ }^{410}$ the Minnesota Attorney General sued the National Arbitration Foundation over its consumer arbitrations; ${ }^{411}$ and public enforcement actions frequently seek judicial relief where an analogous private action would

F.3d 574, 591-92 (6th Cir. 2014). Other courts have declined to follow this reasoning. See, e.g., Benedict v. Hewlett-Packard Co., No. 13-cv-00119-BL, 2016 WL 1213985 (N.D. Cal. Mar. 29, 2016); Mark v. Gawker Media LLC, No. 13-cv-4347(AJN), 2016 WL 1271064 (S.D.N.Y. Mar. 29, 2016); Feamster v. Compucom Sys., Inc., No. 7:15-CV-00564, 2016 WL 722190 (W.D. Va. Feb. 19, 2016). For other examples of class action waivers outside of the arbitration context, see, for example, In re Yahoo! Litig., 251 F.R.D. 459 (C.D. Cal. 2008); Bonanno v. Quizno's Franchise Co., LLC, No. 06-cv-02358-CMAKLM, 2009 WL 1068744 (D. Colo. Apr. 20, 2009).

406. It is possible that an agency would announce such a policy in order to deter the use of arbitration agreements, though I have not found it. Perhaps a better strategy would be a policy that led regulated parties to strongly suspect an emphasis on arbitration - thus achieving deterrence, but not so explicit as to prompt a successful preemption challenge.

407. EEOC, Notice No. 915.002, Policy Statement ON MANDATORY Binding ARBITRATION OF EMPLOYMENT DISCRIMINATION DISPUTES AS A CONDITION OF EMPLOYMENT (1997).

408. See id.

409. See, e.g., EEOC v. Waffle House, Inc., 534 U.S. 279 (2002) (holding that the EEOC has authority to seek victim-specific relief in enforcement action despite an arbitration agreement between employee and employer); supra note 386 (discussing Broussard litigation). Indeed, the EEOC also has attempted to convince courts that making arbitration agreements a condition of employment is contrary to Title VII, independent of any separate discriminatory act. See Borg-Warner Protective Servs. Corp. v. EEOC, 245 F.3d 831 (D.C. Cir. 2001) (rejecting APA challenge to this EEOC policy). Courts have rejected this argument, see Oblix, Inc. v. Winiecki, 374 F.3d 488, 491 (7th Cir. 2004); EEOC v. Luce, Forward, Hamilton \& Scripps, 303 F.3d 994, 1002-04 (9th Cir. 2002) (collecting cases), but the EEOC has continued to press this view. See EEOC v. Doherty Enters., Inc., 126 F. Supp. 3d 1305 (S.D. Fla. 2015).

410. See Final Rule, supra note 377; CFPB STUDY, supra note 396.

411. Geneva-Roth, Capital, Inc. v. Edwards, 956 N.E.2d 1195, 1198 n.4 (Ind. Ct. App. 2011); Nicole Wanlass, Note, No Longer Available: Critiquing the Contradictory Way Courts Treat Exclusive Arbitration Forum Clauses When the Forum Can No Longer Arbitrate, 99 MINN. L. REV. 2005 (2015). 
be sent to arbitration. ${ }^{412}$ In none of these examples did a state or federal agency announce a policy of dedicating enforcement resources toward entities pushing arbitration. But these examples suggest that they might be inclined to do soand it would raise concerns about the sincerity of their anti-arbitration rhetoric if they did not. ${ }^{413}$

\section{Standing Substitutes}

Standing doctrine also seems to close courthouse doors, ${ }^{414}$ but substitute actions may work here as well. ${ }^{415}$ First, and again, state executive actions may be available. Standing seems to be no limit for traditional public enforcement, ${ }^{416}$ and federal courts seem more willing to find standing for public representational suits than for private ones. ${ }^{417}$ As noted above, many federal statutes authorize public enforcement, and many states have parens patriae authority. ${ }^{418}$ Consider again Spokeo v. Robins. ${ }^{419}$ In that case, Robins had difficulty establishing standing to sue under the Fair Credit Reporting Act (FCRA). ${ }^{420}$ But states may enforce the FCRA too, ${ }^{421}$ so if Robins lacks standing to sue Spokeo, government enforcers may step in.

Second, PAGAs are possible standing substitutes. Some federal courts have found "law enforcement standing" for PAGA claims, ${ }^{422}$ tracking the Supreme Court's view of standing for qui tam suits. ${ }^{423}$ Even if federal courts found no standing, recall that many states deviate from federal standing law. ${ }^{424}$ California

412. See supra notes $382,409$.

413. See supra notes 403 and accompanying text.

414. See supra notes $63-68$ and accompanying text.

415. In addition to suggestions made here, no-standing claims are also possible in administrative tribunals and other non-Article III courts to the extent that such tribunals are available. See, e.g., Gardner v. FCC, 530 F.2d 1086, 1090 (D.C. Cir. 1976) ("[A]gencies are free to hear actions brought by parties who might be without party standing if the same issues happened to be before a federal court."). These proceedings should not transgress the judicial-power limit either, see, e.g., Murray's Lessee v. Hoboken Land \& Improvement Co., 59 U.S. 272 (1856), because these cases are not justiciable cases or controversies. See generally Clopton, supra note 65.

416. See, e.g., FEC v. Akins, 524 U.S. 11 (1998); United States v. Raines, 362 U.S. 17 (1960). See generally Edward A. Hartnett, The Standing of the United States: How Criminal Prosecutions Show That Standing Doctrine is Looking for Answers in All the Wrong Places, 97 MICH. L. REV. 2239 (1999).

417. See, e.g., Massachusetts v. EPA, 549 U.S. 497 (2007); Alfred L. Snapp \& Son, Inc. v. Puerto Rico ex rel. Barez, 458 U.S. 592 (1982); see also Lemos, supra note 297, at 497, 502 (making a similar observation); Fallon, supra note 63, at 1081-82 (same).

418. See supra notes 297-304; see also, e.g., Connecticut v. Physicians Health Servs. of Conn., Inc., 287 F.3d 110, 120 (2d Cir. 2002) ("When determining whether a state has parens patriae standing under a federal statute, we ask if Congress intended to allow for such standing.").

419. 136 S. Ct. 1540 (2017); see supra notes 66-68 and accompanying text.

420. Id.

421. See 15 U.S.C. $\S 1681$ s (2012).

422. See, e.g., McKenzie v. Fed. Express Corp., 765 F. Supp. 2d 1222 (C.D. Cal. 2011).

423. See, e.g., Vt. Agency of Nat. Res. v. United States ex rel. Stevens, 529 U.S. 765 (2000). In these cases, a PAGA plaintiff may proceed even if she lacked a personal injury-in-fact.

424. See supra Part II.B. 
PAGA actions thus can be maintained in state court even if a federal court found no standing. ${ }^{425}$

\section{International Law Substitutes}

Substitute actions also could pursue international law claims. ${ }^{426}$ Many putative ATS claims could be the subjects of public actions.

Following Kiobel, scholars focused on the prospect of private plaintiffs bringing state law suits in failed ATS cases. ${ }^{427}$ Public plaintiffs could take the same advice, ${ }^{428}$ and presumably state legislatures could create PAGAs for these claims as well. $^{429}$

A similar suggestion applies to international claims based on US statutes. Not only could state courts interpret state statutes more broadly than parallel federal statutes, ${ }^{430}$ but the Supreme Court also has suggested that extraterritorial public suits under federal statutes might be permissible even when extraterritorial private suits would not be. ${ }^{431}$ Indeed, last term, the Supreme Court limited the extraterritorial effect of RICO for private but not public claims, ${ }^{432}$ despite the fact that the exact same substantive provision of RICO creates the private and public causes of action. ${ }^{433}$

425. See, e.g., Adams v. Luxottica U.S. Holdings Corp., No. SA CV 07-1465 AHS (MLGx), 2009 WL 7401970 (C.D. Cal. July 24, 2009) (remanding PAGA case for lack of Article III standing); see also Env't World Watch, Inc. v. Am. Airlines, Inc., No. C05-1799 THE, 2005 WL 1867728 (N.D. Cal. Aug. 3, 2005) (remanding claim against foreign sovereign, despite the Foreign Sovereign Immunities Act's grant of federal jurisdiction, because plaintiffs lacked federal court standing for "public-interest" claim).

426. See supra notes 87-93 and accompanying text.

427. See generally Symposium, 3 U.C. IRV. L. REV. 1 (2013) (symposium issue for "Human Rights Litigation in State Courts and Under State Law").

428. Criminal actions also might be available in these circumstances even if civil plaintiffs could not obtain personal jurisdiction. See infra Part III.E.

429. See supra notes 342-346 and accompanying text.

430. The presumption against extraterritoriality is a tool of federal statutory interpretation, see supra note 87, and states deviate significantly from the federal approach to these questions. See Caleb Nelson, State and Federal Models of the Interaction Between Statutes and Unwritten Law, 80 U. CHI. L. REV. 657, 720-23 (2013).

431. In Empagran, the Supreme Court suggested more solicitude to extraterritorial public antitrust enforcement as compared with its private analog. F. Hoffmann-LaRoche Ltd. v. Empagran S.A., 542 U.S. 155, 170-71 (2004); see also Morrison v. Nat'l Austl. Bank Ltd., 561 U.S. 247, 284 n.12 (2010) (Stevens, J., concurring in the judgment) (suggesting that the extraterritorial reach of securities law could depend on whether the SEC or a private party sued).

432. RJR Nabisco, Inc., v. European Cmty. 136 S. Ct. 2090 (2016) (applying the presumption against extraterritoriality to the treble-damages provision of RICO). This was the position of the United States as well. See Brief for the United States as Amicus Curiae Supporting Vacatur, RJR Nabisco, Inc. v. European Cmty., 136 S. Ct. 2090 (2016) (No. 15-138), 2015 WL 9268185.

433. See 18 U.S.C. $\S 1962$ (2012). The Court distinguished private suits based on the separate remedial provision authorizing treble damages at 18 U.S.C. $§ 1964$ (c) (2012). 


\section{E. Personal Jurisdiction Substitutes}

Turning finally to personal jurisdiction, note first that constitutional personal jurisdiction law applies with equal force to public actions and to state courts. ${ }^{434}$ Indeed, the seminal personal jurisdiction decision International Shoe v. Washington involved a challenge to a government suit in a state court. ${ }^{435}$ For this reason, the above-proposed substitute suits may not be viable responses to personal jurisdiction law.

Interestingly (and perhaps troublingly), the Supreme Court's personal jurisdiction cases might not constrain an important category of enforcement actions: criminal prosecutions. Many federal and state decisions have held that the Supreme Court's minimum-contacts analysis is not applicable to criminal cases ${ }^{436}$ and the United States Department of Justice ("DOJ") has advanced this position in some criminal prosecutions. ${ }^{437}$ According to the DOJ in a recent case, " $[\mathrm{T}]$ here is no case that applies a minimum-contacts analysis in determining whether a criminal prosecution is arbitrary and fundamentally unfair under the Due Process Clause." ${ }^{, 438}$ The relevant decisions do not appear to distinguish between Fifth (federal) and Fourteenth (state) Amendment due process rights, so state prosecutors could offer the same arguments to overcome due process barriers in state criminal prosecutions.

For better or worse, therefore, prosecutors could bring criminal actions where civil actions are unavailable - assuming, of course, that the standards for criminal liability are met. ${ }^{439}$ This suggestion might be particularly compelling in areas of corporate malfeasance, where criminal and civil penalties converge and law authorizes private restitution. ${ }^{440}$ Criminal prosecutions also might be relevant in international law cases for which personal jurisdiction has been

434. See supra notes $77-81,240$ and accompanying text.

435. Int'l Shoe Co. v. Washington, 326 U.S. 310 (1945).

436. See, e.g., United States v. Ali, 718 F.3d 929 (D.C. Cir. 2013); Boyd v. Meachum, 77 F.3d 60 (2d Cir. 1996); In re Vasquez, 705 N.E.2d 606 (Mass. 1999); State v. Luv Pharmacy, Inc., 388 A.2d 190 (N.H. 1978); Ex parte Boetscher, 812 S.W.2d 600 (Tex. Crim. App. 1991); State v. Amoroso, 975 P.2d 505, 508 (Utah Ct. App. 1999); Rios v. State, 733 P.2d 242 (Wyo. 1987); see also Frisbie v. Collins, 342 U.S. 519 (1952) (permitting prosecution of individual brought into state by "forcible abduction"); Ker v. Illinois, 119 U.S. 436, 444 (1886) (same).

437. See, e.g., Opposition to Defendant Roger Darin's Motion to Dismiss the Criminal Complaint, United States v. William Hayes, 118 F. Supp. 3d 620 (S.D.N.Y. 2015) (No. 12 MJ 3229) (motion denied).

438. Id. at 17 .

439. The mechanism is slightly more complicated. Criminal trials in absentia are not available, so the government instead would pursue an indictment and then seek extradition—or, perhaps cynically, accept the shadow of the indictment as the sanction. See Zachary D. Clopton, Territoriality, Technology, and National Security, 83 U. CHI. L. REV. 45, 58-60 (2016) (discussing this effect in Hijazi and other cases).

440. See generally Adam S. Zimmerman \& David M. Jaros, The Criminal Class Action, 159 U. PA. L. REV. 1385 (2011). For example, DOJ has obtained billions of dollars in criminal restitution from corporate defendants, much of which has been returned to victims. Id. at 1396. 
difficult to obtain. ${ }^{441}$ I am unaware of evidence that prosecutors are selecting cases because civil personal jurisdiction would be unavailable, but this strategy is possible. ${ }^{442}$ Tracking the two categories just mentioned (corporate malfeasance and international law), the DOJ has recently pressed the argument about weaker nexus requirements for criminal prosecutions in cases involving the London Interbank Offered Rate (LIBOR) scandal ${ }^{443}$ and Somali piracy. ${ }^{444}$

\section{F. State-Enforcement Assessment}

This Section has outlined the ways in which public enforcement can respond to the Supreme Court's decisions on class actions, arbitration, standing, international law, and personal jurisdiction. Public enforcement substitutes are free from many of the constraints on state courts acting alone. ${ }^{445}$ Public or private attorney general suits can eschew doctrines that push courts to deny class certification or compel arbitration. ${ }^{446}$ Many of these suits also avoid the pull of federal court jurisdiction. ${ }^{447}$ In this way, public enforcement may be particularly meaningful when private claims are subject to removal or compelled arbitration.

Federal action may limit state public enforcement, but the requisite federal action is not easy to come by. First, federal law could preempt state-enforcement efforts. However, this would require Congress to overcome the presumption against preemption of state $\mathrm{law}^{448}$ and disempower state actors from enforcing the preemptive federal law. ${ }^{449}$ Federal-enforcement actions also could preclude state enforcement by resolving claims or issues. ${ }^{450}$ Here, the federal statute would have to permit such federal actions, the federal enforcer would have to

441. Moreover, although the standards are purportedly the same, it appears that courts are more willing to overcome the presumption against extraterritoriality for criminal cases than civil ones. See Zachary D. Clopton, Bowman Lives: The Extraterritorial Application of U.S. Criminal Law After Morrison v. National Australia Bank, 67 N.Y.U. ANN. SURV. AM. L. 137, 166-72 (2011).

442. See, e.g., James G. Stewart, The Turn to Corporate Criminal Liability for International Crimes: Transcending the Alien Tort Statute, 47 N.Y.U. J. INT'L L. \& POL. 121 (2014).

443. See supra note 438 and accompanying text (discussing Hayes).

444. See United States v. Ali, 718 F.3d 929 (D.C. Cir. 2013).

445. See supra Part III.

446. See supra Parts III.A-B.

447. See, e.g., supra notes 307-309 and accompanying text (discussing parens patriae suits and CAFA); supra note 351 and accompanying text (discussing PAGA and CAFA); supra notes 422-425 and accompanying text (discussing PAGA and standing); supra note 438 and accompanying text (discussing state criminal prosecutions).

448. See, e.g., Wyeth v. Levine, 129 S. Ct. 1187, 1194-95 (2009); N.Y. Cent. R.R. Co. v. Winfield, 244 U.S. 147, 155-58 (1917) (Brandeis, J., dissenting). This is especially significant in the context of state police powers. See, e.g., Arizona v. United States, 132 S. Ct. 2492, 2501 (2012) (internal quotation marks omitted) ("In preemption analysis, courts should assume that the historic police powers of the States are not superseded unless that was the clear and manifest purpose of Congress.").

449. This means excluding states as authorized enforcers, see, e.g., Lemos, supra note 296, at 708-11 (collecting examples), and as parens patriae representatives, see, e.g., Lemos, supra note 297, at 495-97.The Arizona decision may be the exception that proves the rule, given the unusual nature of the federal immigration power. See 132 S. Ct. 2492.

450. See RESTATEMENT (SECOND) OF JUDGMENTS $\S \S 13-29$ (AM. LAW INST. 1982). 
initiate and resolve the claim, and a court would have to stamp the judgment. ${ }^{451}$ In other words, multiple branches of the federal government would need to make concerted efforts for either preemption or preclusion to attach. ${ }^{452}$

But even if public suits survive this federal gauntlet, public enforcement may not substitute perfectly for lost private suits. For one thing, public actions are imperfect substitutes when viewed through the lens of court access. ${ }^{453}$ Public actions might aspire to substitute for private-enforcement deterrence, ${ }^{454}$ but if court access matters regardless of the outcome, then public enforcement must be judged on the process it provides to represented parties. ${ }^{455}$ For some claims, it may be that government representation is never a meaningful substitute for an individual day in court. ${ }^{456}$ Compensation is subject to similar concern-even if public enforcers compensate victims, the compensation may not be sufficient. ${ }^{457}$

There are also formal and functional constraints on state enforcement. Formally, statutes authorizing public enforcement do not always offer the same remedies that are available in private suits. ${ }^{458}$ Geography also may formally constrain state enforcement in a way that would not apply to a nationwide class action. ${ }^{459}$

451. See Clopton, Redundant Enforcement, supra note 315, at 302, 305 (collecting examples of statutes allowing and disallowing intervention or preclusion).

452. See supra notes 448-451 and accompanying text. And, if these conditions were to obtain, that would be consistent with the constitutional structure. See U.S. CONST. art. VI, cl. 2.

453. This Article has suggested that enforcement and court access run together, but that will not always be the case. See generally David Rosenberg, Decoupling Deterrence and Compensation Functions in Mass Tort Class Actions for Future Loss, 88 VA. L. REV. 1871 (2002).

454. See, e.g., Kenneth W. Dam, Class Actions: Efficiency, Compensation, Deterrence, and Conflict of Interest, 4 J. LeGAL STUD. 47 (1975); Bruce Hay \& David Rosenberg, "Sweetheart" and "Blackmail" Settlements in Class Actions: Reality and Remedy, 75 NOTRE DAME L. REV. 1377, 1377 (2000).

455. See, e.g., Lemos, supra note 297, at 531-42.

456. Whether class actions - or even individual litigation as currently practiced - constitute a meaningful day in court is a topic for another day. Cf. Resnik, supra note 16. But it is far from obvious that a class action disposed of at summary judgment meets that standard.

457. See, e.g., Adam S. Zimmerman, Distributing Justice, 86 N.Y.U. L. REV. 500 (2011) (discussing public compensation from various federal agencies); Velikonja, supra note 337, at 333 (noting that the SEC has distributed billions of dollars to investors following public-enforcement actions under the Fair Funds program). Importantly, though, we should measure compensation against the baseline of private suits.

458. See, e.g., Clopton, Redundant Enforcement, supra note 315, at 303-04 (collecting examples). For example, as noted above, the California Attorney General could not pursue compensatory relief against IntelliGender. See supra note 334.

459. Parens patriae suits, for example, are predicated on the relationship between the state and its citizens - it would make less sense for Vermont to sue on behalf of Californians than for a Vermont plaintiff to propose a nationwide class definition. Coordinated multistate litigation has been used in public enforcement, see, e.g., Clopton, Redundant Enforcement, supra note 315, at 288 (collecting sources and critics), but presumably that arrangement adds complexity and cost. 
Functionally, one substantial limit on state enforcement comes from public resources, or lack thereof. Traditional public enforcement is expensive. ${ }^{460}$ It is unrealistic to assume that government agencies have the capacity to bring every enforcement case. Indeed, lawmakers often authorized private enforcement in response to the insufficiency of public enforcement, so it is unsurprising that public enforcement is not a perfect substitute. ${ }^{461}$

Another functional limit on state enforcement is political will. Majoritarian pressures may make public enforcement less effective at protecting minority interests than private alternatives. ${ }^{462} \mathrm{We}$ might also worry that public agencies will be soft on political allies. ${ }^{463}$ Public enforcement may be particularly problematic when state actors are defendants: substituting state enforcement might systematically undermine attempts to hold state actors accountable. Indeed, following the weakening of private remedies for police misconduct, ${ }^{464}$ Congress concluded that the federal government needed the ability to enjoin unconstitutional police practices in the states, and it provided the DOJ with that power in 42 U.S.C. $\S 14141 .{ }^{465}$ Section 14141 , however, may be a cautionary tale for public enforcement: a lack of resources and political will has hampered the DOJ's effective use of that statute. ${ }^{466}$

Notably, these formal and functional limits are, in a sense, self-imposed. If a state wanted to use public enforcement to respond to the Supreme Court's procedural retrenchment, it could authorize, fund, and monitor a robust publicenforcement program. This study thus provides a roadmap for public enforcers, as well as a rubric against which they can be evaluated. ${ }^{467}$ PAGAs also may represent an antidote to problems of resources and executive priorities. PAGAs are uncommon today and, where they exist, they are remedially limited. ${ }^{468}$ But this too could be corrected in the states.

460. See, e.g., Burbank et al., supra note 4; Clopton, Redundant Enforcement, supra note 315. Public enforcers may have adopted these strategies but have not publicized them. For instrumentalist or inherent reasons, there may be a norm against revealing enforcement priorities.

461. See, e.g., FARHANG, supra note 14.

462. See, e.g., Zachary D. Clopton, Diagonal Public Enforcement, 70 STAN. L. REV. (forthcoming 2018) (developing this claim in the interjurisdictional context).

463. See, e.g., Clopton, Redundant Enforcement, supra note 315, at 323.

464. See, e.g., City of Los Angeles v. Lyons, 461 U.S. 95 (1983).

465. See Violent Crime Control and Law Enforcement Act of 1994, 42 U.S.C. § 14141 (2012) (transferred to 34 U.S.C.A. $§ 12601$ (West 2017)).

466. See, e.g., Myriam E. Gilles, Reinventing Structural Reform Litigation: Deputizing Private Citizens in the Enforcement of Civil Rights, 100 COLUM. L. REV. 1384, 1407-12 (2000); Rachel A. Harmon, Promoting Civil Rights Through Proactive Policing Reform, 62 STAN L. REV. 1, 52-55 (2009).

467. For example, the EEOC and CFPB have been critical of the Supreme Court's arbitration jurisprudence, and they have responded in ways explained above. See supra notes 406-412 and accompanying text. One could imagine in-the-weeds investigations of public enforcement operations as well as big data studies of enforcement decisions in response to the background legal landscape.

468. See supra notes 342-363. 
In sum, state enforcement in practice may represent far less than a perfect substitute for private enforcement. But just as with state courts, it is important to acknowledge that its limits are not the product of the Supreme Court alone. ${ }^{469}$

IV.

\section{THE POLITICS OF PROCEDURE}

Many of the criticisms of the Roberts Court's procedural decisions boil down to a concern that the Court is laundering substantive policymaking through procedure. ${ }^{470}$ True enough, but we have long since recognized that the Supreme Court is a political actor, ${ }^{471}$ and procedure is part of the iterative process of politics. ${ }^{472}$ While this Article cannot tell us whether the Supreme Court's procedural decisions were right or wrong, we might be able to get normative traction by considering the politics of procedure and the responses to it.

\section{A. Reasons for Optimism}

Straightforwardly, critics of Twombly and Iqbal, or Wal-Mart v. Dukes, might revel in state court rejection or state-enforcement substitution. ${ }^{473}$ And they might use this Article to agitate for more state intervention. Moreover, by documenting state court and state-enforcement alternatives, this Article offers some reasons for optimism about procedural federalism generally.

Part II of this Article reviewed the ways that state courts have exercised judicial federalism. Federalism is valuable (in part) because it can generate experimentation and diversification - states as "laboratories of democracy." 474 But there is some concern in the literature that states do not in fact experiment with policy. ${ }^{475}$ Civil procedure has long been an area of significant state

469. See supra Part II.E.

470. See supra Part I.

471. See, e.g., Richard A. Posner, Foreword: A Political Court, 119 HARV. L. REV. 31 (2005) (characterizing the Supreme Court as a "political organ"). Then-Judge Posner focused on the Court's constitutional docket, but much of his analysis applies equally outside of it.

472. After all, "procedure is power." Stephen B. Burbank, The Bitter with the Sweet: Tradition, History, and Limitations on Federal Judicial Power-A Case Study, 75 NOTRE DAME L. Rev. 1291, 1292 (2000). Saying that these decisions are part of a political process is not pejorative. Politics is but one way to resolve policy questions.

473. After all, this is politics all the way down.

474. See New State Ice Co. v. Liebmann, 285 U.S. 262, 311 (1932) (Brandeis, J., dissenting) ("It is one of the happy incidents of the federal system that a single courageous State may, if its citizens choose, serve as a laboratory; and try novel social and economic experiments without risk to the rest of the country."). See generally Heather K. Gerken, Foreword: Federalism All the Way Down, 124 HARV. L. REV. 4 (2010) (offering a "nationalist" account of federalism); Larry Kramer, Understanding Federalism, 47 VAND. L. REV. 1485 (1994) (offering a theory of "process federalism").

475. See generally Susan Rose-Ackerman, Risk Taking and Reelection: Does Federalism Promote Innovation?, 9 J. LEGAL STUD. 593 (1980); Brian Galle \& Joseph Leahy, Laboratories of Democracy? Policy Innovation in Decentralized Governments, 58 EMORY L.J. 1333 (2009). 
autonomy, and this Article provides evidence that state courts, in practice, have used their authority to experiment with procedure. ${ }^{476}$

There is also some anecdotal evidence that procedural experimentation diffuses among courts. In Twombly, Justice Stevens relied on state court experiences with pleading standards to argue against "plausibility pleading." 477 Many of the decisions in which state courts reject federal procedure cite to other states doing the same. ${ }^{478}$ States that voluntarily follow federal procedure are themselves examples of policy diffusion. ${ }^{479}$

Although this state experimentation is not systematic - there is not a central planner matching similar states and applying procedural treatments ${ }^{480}$ - the hodgepodge of state procedural choices documented in Part II may generate interesting data. Consider, for one example, the intersection among state standards for pleading and summary judgment. ${ }^{481}$

476. See supra Part II. This has not always been true. For example, some framers of the Federal Rules hoped their document would be a focal point for state procedure, see Charles Alan Wright, Procedural Reform in the States, 24 F.R.D. 85 (1959), while the Conformity Act before that told federal courts to track state procedure. See 4 WRIGHT \& MILLER, supra note $168, \S 1002$.

477. See Bell Atl. Corp. v. Twombly, 550 U.S. 544, 578 (2007) (Stevens, J., dissenting); see also supra Part III.A.1 (updating results).

478. See supra Part II.A (collecting cases).

479. See supra Part II.A (collecting cases).

480. See, e.g., Koleman S. Strumpf, Does Government Decentralization Increase Policy Innovation?, 4 J. PUB. ECON. THEORY 207 (2002) (using game theory to model different modes of experimentation under which the central government cannot require particular policy experiments in particular sub-units).

481. For citations, see infra Appendix 1-2. Again, "rejecting Celotex" means rejecting it in whole or in part. See supra note 147 and accompanying text. 
Table C—Celotex \& Pleading Standards

\begin{tabular}{|c|c|c|c|c|}
\hline & \multicolumn{2}{|c|}{ Notice } & Plausibility & Fact \\
\hline $\begin{array}{c}\text { Applying } \\
\text { Celotex }\end{array}$ & $\begin{array}{l}\text { Alabama } \\
\text { Alaska } \\
\text { Arizona } \\
\text { Hawai'i } \\
\text { Idaho } \\
\text { Iowa } \\
\text { Kansas } \\
\text { Maine } \\
\text { Michigan } \\
\text { Minnesota } \\
\text { Mississippi } \\
\text { Montana }\end{array}$ & $\begin{array}{l}\text { Nevada } \\
\text { New Hamp. } \\
\text { New Jersey } \\
\text { N. Carolina } \\
\text { N. Dakota } \\
\text { Ohio } \\
\text { Rhode Island } \\
\text { Tennessee } \\
\text { Vermont } \\
\text { Washington } \\
\text { West Virginia } \\
\text { Wyoming }\end{array}$ & $\begin{array}{l}\text { Colorado } \\
\text { Dist. of } \\
\text { Columbia } \\
\text { Massachusetts } \\
\text { Nebraska } \\
\text { South Dakota } \\
\text { Wisconsin }\end{array}$ & $\begin{array}{l}\text { Arkansas } \\
\text { California } \\
\text { Delaware } \\
\text { Illinois } \\
\text { Louisiana } \\
\text { Maryland } \\
\text { Pennsylvania } \\
\text { South Carolina }\end{array}$ \\
\hline $\begin{array}{c}\text { Rejecting } \\
\text { Celotex }\end{array}$ & $\begin{array}{l}\text { Georgia } \\
\text { Indiana } \\
\text { Kentucky } \\
\text { New Mexico } \\
\text { New York }\end{array}$ & $\begin{array}{l}\text { Oklahoma } \\
\text { (Texas) } \\
\text { Utah } \\
\text { Virginia }\end{array}$ & (Texas) $^{482}$ & $\begin{array}{l}\text { Connecticut } \\
\text { Florida } \\
\text { Missouri } \\
\text { Oregon }\end{array}$ \\
\hline
\end{tabular}

These interactions do not imply any particular normative conclusion, but they suggest that state policy choices on pleading and summary judgment are sufficiently diverse to allow for fruitful investigation. Or, note that among the fourteen states in which courts cited approvingly to Scott v. Harris on summary judgment, the proportion of Celotex to non-Celotex states is roughly the same as the proportion among all states. ${ }^{483}$ The empirics of Twombly and Iqbal may be uncertain, ${ }^{484}$ but that does not mean that procedural data are never meaningful. ${ }^{485}$ If such data are meaningful, only a political process can translate that meaning into policy.

482. I have put Texas in parentheses to indicate the split among Texas courts - so one could study a jurisdiction rejecting Celotex and applying plausibility by looking at a subset of Texas courts. See supra note 127 (discussing split in Texas authority).

483. See supra Part II.A.2 (collecting cases). About 29 percent of the states applying Scott $v$. Harris rejected Celotex, and approximately 25 percent of states rejected Celotex. The non-Celotex states citing Scott are Connecticut, Georgia, Kentucky, and New Mexico. The Celotex states citing Scott are Arkansas, Delaware, Maine, Michigan, Mississippi, Montana, New Jersey, Ohio, Pennsylvania, and Washington.

484. See supra note 26 .

485. See, e.g., Jonah B. Gelbach, Can We Learn Anything About Pleading Changes from Existing Data?, 44 INT'L REV. L. ECON. 72, 72 (2015) (“[Civil procedure] researchers should not let the perfect be the enemy of the good: even data protocols that are less than perfectly designed may be broadly useful."). 
Turning to state enforcement, Part III demonstrated that state executives participate in policymaking through the exercise of their enforcement discretion. Indeed, this Article demonstrates that public enforcement has the capacity to respond precisely to the Supreme Court's procedural decisions that have generated the most political outcry. ${ }^{486}$ In this way, this Article also provides a doctrinal template for public scrutiny of state-enforcement choices. ${ }^{487}$

Theoretically, there are reasons that public-enforcement substitutes might be an auspicious development. Public enforcement can be coordinated across cases or issues. ${ }^{488}$ It can select cases based on the interests of the polity rather than the highest possible damage award or attorney fee. ${ }^{489}$ It might be easier to name and shame the attorney general for underenforcement than to vote out a legislator for sub-optimally incentivizing private suits. ${ }^{490}$ And I have noted throughout this Article examples of courts concluding that public enforcement is not just a substitute but an improvement. ${ }^{491}$ They could be right.

\section{B. Reasons for Concern}

Even for those troubled by the Supreme Court's recent procedural retrenchment (and encouraged by the responses documented above), this paper should not be read as an entirely happy story. The state-level developments described in this paper are necessarily limited, and they raise new issues that are not altogether encouraging.

First, as noted above, many factors constrain state procedure and public enforcement. Federal jurisdiction, removal, and preemption blunt the effects of state court decisions. ${ }^{492}$ This is especially significant for the private enforcement of federal statutory rights. ${ }^{493}$ Public suits can dodge some of these limits, but resources, political will, and remedial options may hold back robust public enforcement. ${ }^{494}$ These limitations suggest that large swaths of cases are immune

486. See supra Part III.

487. Id.

488. See, e.g., Clopton, supra note 462, (discussing this argument and collecting sources).

489. See id.

490. Zachary Price offered a similar structural account of the politics of enforcement discretion: "In an era of partisan polarization and legislative gridlock, Presidents often cannot count on Congress to develop legislative solutions to perceived problems, or even to negotiate over such solutions in good faith. Nevertheless, the public increasingly holds the President accountable for all failures of national policy." Zachary S. Price, Enforcement Discretion and Executive Duty, 67 VAND. L. REV. 671, 687 (2014).

491. Recall that the Southern District of Georgia invited public enforcement against H \& R Block when private enforcement was not available, see supra note 313 and accompanying text, and the Fifth Circuit suggested that a class waiver in an arbitration clause was less problematic because public enforcement was available. See supra note 383 and accompanying text. Many courts have held that public enforcement actions are "superior" to private class actions, and the legislature of Maryland codified this preference for public suits over class actions. See supra note 312.

492. See supra Part II.E.

493. See id.

494. See supra Part III.F. 
from some or all of the responses described in this Article. ${ }^{495}$ To put it affirmatively, critics of the Supreme Court's procedural decision will need to demand significant legislative and executive action to make state responses fully effective.

Rethinking these findings through the frame of politics also raises questions of political economy. Turning first to state courts, we might expect that the procedural nature of these issues insulates them from pure politics. To engage with procedure, one needs to acquire technical expertise and professional experience. But these features of procedure also make procedural politics less transparent. If civil procedure scholars are not closely following the developments of state procedural law, ${ }^{496}$ then it is doubtful that state procedure is subject to anything close to intense public scrutiny. The technical nature of procedure further hinders transparency, and simultaneously gives it an aura of neutrality even if not warranted. Fragmenting procedure into fifty-plus jurisdictions further challenges effective monitoring. ${ }^{497}$

In addition, the price of political influence in state courts is not high. ${ }^{498}$ Many states hold judicial elections, and although spending in these elections has increased, it is still relatively low compared to other races. ${ }^{499}$ As a result, a few interested parties could effectively influence state judicial politics. ${ }^{500}$ For example, in one high profile case, an Atlanta billionaire allegedly attempted to sway a judicial election in Montana-with an eye toward his pending business in the state supreme court - for the (relatively) low price of $\$ 100,000 .^{501}$

Judicial politics may not have a consistent ideological valence. It may be that, in some areas, trial lawyers or other traditionally liberal groups could be major players. But regardless of the policy outputs, there are democratic reasons to temper optimism for the politics of state procedure. There also are empirical reasons to think that campaign contributions can affect partisan judicial elections. For example, Joanna Shepherd showed empirically the intuitive result that "contributions from interest groups are associated with increases in the

495. These limits also suggest a cynical interpretation of courts' stated preferences for public enforcement. See, e.g., supra notes $68,312,383,414,431-433$ and accompanying text (collecting examples of those stated preferences).

496. See supra Part II (collecting sources).

497. In future work, I attempt to overcome some of those challenges.

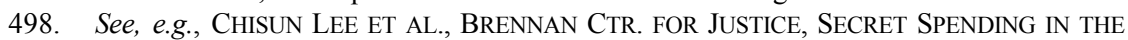
STATES 3, 17-18 (2016) [hereinafter BRENNAN CTR. REPORT].

499. See, e.g., id. at 3; Michael S. Kang \& Joanna M. Shepherd, Partisanship in State Supreme Courts: The Empirical Relationship Between Party Campaign Contributions and Judicial Decision Making, 44 J. LEGAL STUD. S161, S165-66 (2015) (collecting sources and documenting correlation between political party contributions and judicial behavior in partisan cases).

500. See, e.g., Pranab Bardhan \& Dilip Mookherjee, Capture and Governance at Local and National Levels, 90 AM. ECON. REV. 135, 135 (2000) (noting the common view that "the lower the level of government, the greater is the extent of capture by vested interests, and the less protected minorities and the poor tend to be").

501. See, e.g., BRENNAN CTR. REPORT, supra note 498, at 11 (describing case and citing sources). 
probability that judges will vote for the litigants favored by those interest groups." ${ }^{, 502}$ Professors Kang and Shepherd also showed that "every dollar of contributions from business groups is associated with increases in the probability that elected judges will decide for business litigants." ${ }^{, 503}$

Meanwhile, an understanding of public enforcement as law enforcement may shield public enforcement from scrutiny. ${ }^{504}$ And yet, public enforcement responses have the capacity to be even more political than court procedure. Indeed, it would be quite surprising if some partisan executive officials were not more political than federal judges with life tenure. Returning to an earlier observation, even if public enforcement had sufficient resources (a big if), ${ }^{505}$ we might worry that substituting public suits would systematically harm individuals with claims against government actors or defendants with political sway. ${ }^{506}$ And, again, the price is likely low. ${ }^{507}$ For example, according to the Utah State Legislature, the State's attorney general appeared to have coordinated with payday lenders to exchange leniency in public enforcement for about $\$ 450,000$ in undisclosed campaign contributions. ${ }^{508}$ In short, therefore, when the Supreme Court limits private enforcement, it undercuts a potential tool to check public enforcement, ${ }^{509}$ not to mention a tool to increase enforcement and deterrence overall. $^{510}$

\section{CONCLUSION}

In sum, although the Supreme Court has been the fulcrum of this Article's analysis, it is Congress that often sets the terms of procedural politics. When Congress employs litigation as a tool of federal law enforcement, it necessarily delegates some authority to courts to set enforcement standards. ${ }^{511}$ When Congress provides concurrent jurisdiction over federal claims, it impliedly authorizes state judges to affect enforcement levels through procedure. ${ }^{512}$ When

502. Joanna M. Shepherd, Money, Politics, and Impartial Justice, 58 DUKE L.J. 623, 629 (2009) (studying contributions from pro-business groups, pro-labor groups, doctor groups, insurance companies, and lawyer groups).

503. Michael S. Kang \& Joanna M. Shepherd, The Partisan Price of Justice: An Empirical Analysis of Campaign Contributions and Judicial Decisions, 86 N.Y.U. L. REV. 69, 73 (2011).

504. See, e.g., 5 U.S.C. § 552(b)(7) (2012) (FOIA law enforcement exception).

505. See supra Part III.F.

506. Id.

507. See supra notes $498-501$ and accompanying text.

508. See, e.g., BRENNAN CTR. REPORT, supra note 498, at 11-12 (describing this case and citing sources); UTAH HOUSE OF REPRESENTATIVES, REPORT OF THE SPECIAL INVESTIGATIVE COMMITTEE (2014), http://le.utah.gov/investigative/Final_Report_simple.pdf [https://perma.cc/3SR3-JRSR].

509. This is a tool that could be used by legislators or the public.

510. See supra note 454 and accompanying text.

511. See, e.g., FARHANG, supra note 14, at 49-54.

512. See, e.g., Tafflin v. Levitt, 493 U.S. 455, 459 (1990) (observing that there is a "deeply rooted presumption in favor of concurrent state court jurisdiction”); 13 CHARLES ALAN WRIGHT \& ARTHUR R. Miller, Federal Practice and Procedure: Jurisdiction $§ 3527$ (3d ed. 2017 Update) (collecting cases). 
Congress taps state attorneys general, it invites state executives into the policymaking process. ${ }^{513}$

This Article shows that state courts and enforcement agencies are important sites for political contestation. Thus, when Congress involves state judges or executives, it takes those judges and executives as it finds them-as political animals, or at least as political actors.

513. See supra notes 299-304 and accompanying text. 


\section{APPENDIX 1}

\section{Pleading CASes}

\begin{tabular}{|c|c|c|c|c|}
\hline State & $\begin{array}{l}\text { Accepting } \\
\text { Plausibility }\end{array}$ & $\begin{array}{l}\text { Rejecting } \\
\text { Plausibility }\end{array}$ & $\begin{array}{l}\text { Current } \\
\text { Standard }\end{array}$ & Current Citation \\
\hline Alabama & & $\begin{array}{l}\text { Thomas v. } \\
\text { Williams, } 21 \text { So. } \\
\text { 3d 1234, } 1236 \text { n.1 } \\
\text { (Ala. Civ. App. } \\
\text { 2008). }\end{array}$ & Notice & $\begin{array}{l}\text { Gilley v. S. } \\
\text { Research Inst., } 176 \\
\text { So. 3d 1214, } 1220 \\
\text { (Ala. 2015). }\end{array}$ \\
\hline Alaska & $\begin{array}{l}\text { NO DEFINITIVE } \\
\text { CASES }\end{array}$ & $\begin{array}{l}\text { NO DEFINITIVE } \\
\text { CASES }\end{array}$ & Notice & $\begin{array}{l}\text { Foondle v. } \\
\text { O’Brien, } 346 \text { P.3d } \\
970,973 \text { (Alaska } \\
2015 \text { ). }\end{array}$ \\
\hline Arizona & & $\begin{array}{l}\text { Cullen v. Auto- } \\
\text { Owners Ins. Co., } \\
189 \text { P.3d } 344 \\
\text { (Ariz. 2008) (en } \\
\text { banc). }\end{array}$ & Notice & $\begin{array}{l}\text { Coleman v. City of } \\
\text { Mesa, } 284 \text { P.3d } \\
863,867 \text { (Ariz. } \\
\text { 2012) (en banc). }\end{array}$ \\
\hline Arkansas & $\begin{array}{l}\text { NO DEFINITIVE } \\
\text { CASES }\end{array}$ & $\begin{array}{l}\text { NO DEFINITIVE } \\
\text { CASES }\end{array}$ & Fact & $\begin{array}{l}\text { Duit Constr. Co., } \\
\text { Inc. v. Ark. State } \\
\text { Claims Comm'n, } \\
476 \text { S.W.3d } 791 \\
\text { (Ark. 2015). }\end{array}$ \\
\hline California & $\begin{array}{l}\text { NO DEFINITIVE } \\
\text { CASES }\end{array}$ & $\begin{array}{l}\text { NO DEFINITIVE } \\
\text { CASES }\end{array}$ & Fact & $\begin{array}{l}\text { Lee v. Hanley, } 354 \\
\text { P.3d } 334 \text { (Cal. } \\
\text { 2015). }\end{array}$ \\
\hline Colorado & $\begin{array}{l}\text { Warne v. Hall, } \\
373 \text { P.3d 588, 595 } \\
\text { (Colo. 2016) (en } \\
\text { banc). }\end{array}$ & & Plausibility & $\begin{array}{l}\text { Warnc v. Hall, } 373 \\
\text { P.3d 588, 595 } \\
\text { (Colo. 2016) (en } \\
\text { banc). }\end{array}$ \\
\hline Conn. & $\begin{array}{l}\text { NO DEFINITIVE } \\
\text { CASES }\end{array}$ & $\begin{array}{l}\text { NO DEFINITIVE } \\
\text { CASES }\end{array}$ & Fact & $\begin{array}{l}\text { White v. Mazda } \\
\text { Motor of Am., Inc. } \\
99 \text { A.3d 1079, } \\
1091 \text { (Conn. 2014). }\end{array}$ \\
\hline Delaware & & $\begin{array}{l}\text { Cent. Mortg. Co. } \\
\text { v. Morgan Stanley } \\
\text { Mortg. Capital } \\
\text { Holdings LLC, } 27 \\
\text { A.3d 531, 537 } \\
\text { (Del. 2011). }\end{array}$ & Unclear & \\
\hline $\begin{array}{l}\text { Dist. of } \\
\text { Columbia }\end{array}$ & $\begin{array}{l}\text { Potomac Dev. } \\
\text { Corp. v. District } \\
\text { of Columbia, } 28 \\
\text { A.3d 531, 544 } \\
\text { (D.C. Ct. App. } \\
\text { 2011). }\end{array}$ & & Plausibility & $\begin{array}{l}\text { Poola v. Howard } \\
\text { Univ., } 147 \text { A.3d } \\
\text { 267, } 276 \text { (D.C. Ct. } \\
\text { App. 2016). }\end{array}$ \\
\hline Florida & $\begin{array}{l}\text { NO DEFINITIVE } \\
\text { CASES }\end{array}$ & $\begin{array}{l}\text { NO DEFINITIVE } \\
\text { CASES }\end{array}$ & Fact & $\begin{array}{l}\text { Berrios v. Deuk } \\
\text { Spine, } 76 \text { So. 3d } \\
967,970 \text { n.1 (Fla. } \\
\text { Dist. Ct. App. } \\
\text { 2011). } \\
\end{array}$ \\
\hline Georgia & & $\begin{array}{l}\text { Bush v. Bank of } \\
\text { N.Y. Mellon, } 720 \\
\text { S.E.2d 370, } 375 \\
\text { n.13 (Ga. Ct. App. } \\
\text { 2011). }\end{array}$ & Notice & $\begin{array}{l}\text { Austin v. Clark, } \\
755 \text { S.E.2d 796, } \\
800 \text { (Ga. 2014) } \\
\text { (Nahmias, J., } \\
\text { concurring). }\end{array}$ \\
\hline
\end{tabular}




\begin{tabular}{|c|c|c|c|c|}
\hline State & $\begin{array}{l}\text { Accepting } \\
\text { Plausibility }\end{array}$ & $\begin{array}{l}\text { Rejecting } \\
\text { Plausibility }\end{array}$ & $\begin{array}{l}\text { Current } \\
\text { Standard }\end{array}$ & Current Citation \\
\hline Hawai'i & $\begin{array}{l}\text { NO DEFINITIVE } \\
\text { CASES }\end{array}$ & $\begin{array}{l}\text { NO DEFINITIVE } \\
\text { CASES }\end{array}$ & Notice & $\begin{array}{l}\text { Kealoha v. } \\
\text { Machado, } 315 \text { P.3d } \\
\text { 213, } 216 \text { (Haw. } \\
\text { 2013). }\end{array}$ \\
\hline Idaho & $\begin{array}{l}\text { NO DEFINITIVE } \\
\text { CASES }\end{array}$ & $\begin{array}{l}\text { NO DEFINITIVE } \\
\text { CASES }\end{array}$ & Notice & $\begin{array}{l}\text { Colafranceschi v. } \\
\text { Briley, } 355 \text { P.3d } \\
1261 \text { (Idaho 2015). }\end{array}$ \\
\hline Illinois & $\begin{array}{l}\text { NO DEFINITIVE } \\
\text { CASES }\end{array}$ & $\begin{array}{l}\text { NO DEFINITIVE } \\
\text { CASES }\end{array}$ & Fact & $\begin{array}{l}\text { Hadley v. Doe, } 34 \\
\text { N.E.3d 549, } 556 \\
\text { (Ill. 2015). }\end{array}$ \\
\hline Indiana & $\begin{array}{l}\text { NO DEFINITIVE } \\
\text { CASES }\end{array}$ & $\begin{array}{l}\text { NO DEFINITIVE } \\
\text { CASES }\end{array}$ & Notice & $\begin{array}{l}\text { Schmidt v. Indiana } \\
\text { Ins. Co., } 45 \text { N.E.3d } \\
781,786 \text { (Ind. } \\
2015 \text { ). }\end{array}$ \\
\hline Iowa & & $\begin{array}{l}\text { Hawkeye } \\
\text { Foodservice } \\
\text { Distrib., Inc. v. } \\
\text { Iowa Educators } \\
\text { Corp., } 812 \\
\text { N.W.2d 600, } 608 \\
\text { (Iowa 2012). }\end{array}$ & Notice & $\begin{array}{l}\text { Hawkeye } \\
\text { Foodservice } \\
\text { Distrib., Inc. v. } \\
\text { Iowa Educators } \\
\text { Corp., } 812 \text { N.W.2d } \\
600,608 \text { (Iowa } \\
\text { 2012). }\end{array}$ \\
\hline Kansas & & $\begin{array}{l}\text { Smith v. State, No. } \\
\text { 104,775, 2012 WL } \\
\text { 1072756, at *6 } \\
\text { (Kan. Ct. App. } \\
\text { Mar. 23, 2012). }\end{array}$ & Notice & $\begin{array}{l}\text { Berry v. Nat'1 Med. } \\
\text { Servs., Inc., } 257 \\
\text { P.3d 287, } 288 \\
\text { (Kan. 2011). }\end{array}$ \\
\hline Kentucky & $\begin{array}{l}\text { NO DEFINITIVE } \\
\text { CASES }\end{array}$ & $\begin{array}{l}\text { NO DEFINITIVE } \\
\text { CASES }\end{array}$ & Notice & $\begin{array}{l}\text { Pete v. Anderson, } \\
413 \text { S.W.3d 291, } \\
301 \text { (Ky. 2013). }\end{array}$ \\
\hline Louisiana & $\begin{array}{l}\text { NO DEFINITIVE } \\
\text { CASES }\end{array}$ & $\begin{array}{l}\text { NO DEFINITIVE } \\
\text { CASES }\end{array}$ & Fact & $\begin{array}{l}\text { McCarthy v. } \\
\text { Evolution Petrol. } \\
\text { Corp., } 180 \text { So. 3d } \\
\text { 252, } 257 \text { (La. } \\
\text { 2015). }\end{array}$ \\
\hline Maine & $\begin{array}{l}\text { NO DEFINITIVE } \\
\text { CASES }\end{array}$ & $\begin{array}{l}\text { NO DEFINITIVE } \\
\text { CASES }\end{array}$ & Notice & $\begin{array}{l}\text { Marshall v. Town } \\
\text { of Dexter, } 125 \\
\text { A.3d 1141, } 1143 \\
\text { n.1 (Me. 2015). }\end{array}$ \\
\hline Maryland & $\begin{array}{l}\text { NO DEFINITIVE } \\
\text { CASES }\end{array}$ & $\begin{array}{l}\text { NO DEFINITIVE } \\
\text { CASES }\end{array}$ & Fact & $\begin{array}{l}\text { Khalifa v. } \\
\text { Shannon, 945 A.2d } \\
\text { 1244, 1256-57 } \\
\text { (Md. 2008). }\end{array}$ \\
\hline Mass. & $\begin{array}{l}\text { Iannacchino v. } \\
\text { Ford Motor Co., } \\
888 \text { N.E.2d 879, } \\
890 \text { (Mass. 2008). } \\
\end{array}$ & & Plausibility & $\begin{array}{l}\text { Edwards v. } \\
\text { Commonwealth, } 76 \\
\text { N.E.3d 248, 254 } \\
\text { (Mass. 2017). }\end{array}$ \\
\hline Michigan & $\begin{array}{l}\text { NO DEFINITIVE } \\
\text { CASES }\end{array}$ & $\begin{array}{l}\text { NO DEFINITIVE } \\
\text { CASES }\end{array}$ & Notice & $\begin{array}{l}\text { Yono v. Dep't. of } \\
\text { Transp., 858 } \\
\text { N.W.2d 128, } 135 \\
\text { (Mich. Ct. App. } \\
\text { 2014). }\end{array}$ \\
\hline Minnesota & & $\begin{array}{l}\text { Walsh v. U.S. } \\
\text { Bank, N.A., } 851 \\
\text { N.W.2d 598, } 603 \\
\text { (Minn. 2014). }\end{array}$ & Notice & $\begin{array}{l}\text { Walsh v. U.S. } \\
\text { Bank, N.A., } 851 \\
\text { N.W.2d 598, } 603 \\
\text { (Minn. 2014). }\end{array}$ \\
\hline Miss. & $\begin{array}{l}\text { NO DEFINITIVE } \\
\text { CASES }\end{array}$ & $\begin{array}{l}\text { NO DEFINITIVE } \\
\text { CASES }\end{array}$ & Notice & $\begin{array}{l}\text { Scafidi v. Hille, } \\
180 \text { So. 3d 634, } \\
650 \text { (Miss. 2015). }\end{array}$ \\
\hline
\end{tabular}




\begin{tabular}{|c|c|c|c|c|}
\hline State & $\begin{array}{l}\text { Accepting } \\
\text { Plausibility }\end{array}$ & $\begin{array}{l}\text { Rejecting } \\
\text { Plausibility }\end{array}$ & $\begin{array}{l}\text { Current } \\
\text { Standard }\end{array}$ & Current Citation \\
\hline Missouri & $\begin{array}{l}\text { NO DEFINITIVE } \\
\text { CASES }\end{array}$ & $\begin{array}{l}\text { NO DEFINITIVE } \\
\text { CASES }\end{array}$ & Fact & $\begin{array}{l}\text { Sides v. St. } \\
\text { Anthony's Med. } \\
\text { Ctr., 258 S.W.3d } \\
811,823 \text { (Mo. } \\
\text { 2009) (en banc). }\end{array}$ \\
\hline Montana & & $\begin{array}{l}\text { Britz v. Metro. } \\
\text { Gen. Ins. Co., } 285 \\
\text { P.3d 494, 500 } \\
\text { (Mont. 2012). }\end{array}$ & Notice & $\begin{array}{l}\text { Griffin v. Moseley, } \\
234 \text { P.3d 869, } 877 \\
\text { (Mont. 2010). }\end{array}$ \\
\hline Nebraska & $\begin{array}{l}\text { Doe v. Bd. Of } \\
\text { Regents of the } \\
\text { Univ. of Neb., } 788 \\
\text { N.W.2d 264, } 278 \\
\text { (Neb. 2010). }\end{array}$ & & Plausibility & $\begin{array}{l}\text { Funk v. Lincoln- } \\
\text { Lancaster Cty. } \\
\text { Crime Stoppers, } \\
\text { Inc., } 885 \text { N.W.2d } \\
\text { 1, 13-14 (Neb. } \\
\text { 2016). }\end{array}$ \\
\hline Nevada & & $\begin{array}{l}\text { Garcia v. } \\
\text { Prudential Ins. Co. } \\
\text { of Am., } 293 \text { P.3d } \\
869,871 \text { n.2 (Nev. } \\
2013) .\end{array}$ & Notice & $\begin{array}{l}\text { Nutton v. Sunset } \\
\text { Station, Inc., } 357 \\
\text { P.3d 966, 974 } \\
\text { (Nev. 2015). }\end{array}$ \\
\hline $\begin{array}{l}\text { New } \\
\text { Hampshire }\end{array}$ & $\begin{array}{l}\text { NO DEFINITIVE } \\
\text { CASES }\end{array}$ & $\begin{array}{l}\text { NO DEFINITIVE } \\
\text { CASES }\end{array}$ & Notice & $\begin{array}{l}\text { City of Keene v. } \\
\text { Cleaveland, } 118 \\
\text { A.3d 253, 263 } \\
\text { (N.H. 2015). }\end{array}$ \\
\hline $\begin{array}{l}\text { New } \\
\text { Jersey }\end{array}$ & $\begin{array}{l}\text { NO DEFINITIVE } \\
\text { CASES }\end{array}$ & $\begin{array}{l}\text { NO DEFINITIVE } \\
\text { CASES }\end{array}$ & Notice & $\begin{array}{l}\text { Major v. Maguire, } \\
\text { 128 A.3d 675, } \\
\text { 689-90 (N.J. } \\
\text { 2016). }\end{array}$ \\
\hline $\begin{array}{l}\text { New } \\
\text { Mexico }\end{array}$ & & $\begin{array}{l}\text { Madrid v. Vill. of } \\
\text { Chama, } 283 \text { P.3d } \\
\text { 871, } 876 \text { (N.M. } \\
\text { Ct. App. 2012). }\end{array}$ & Notice & $\begin{array}{l}\text { Deutsche Bank } \\
\text { Nat'l. Trust Co. v. } \\
\text { Johnston, } 369 \text { P.3d } \\
\text { 1046, } 1055 \text { (N.M. } \\
\text { 2016). }\end{array}$ \\
\hline New York & & $\begin{array}{l}\text { Krause v. Lancer } \\
\text { \& Loader Grp., } \\
\text { LLC, } 965 \\
\text { N.Y.S.2d 312, } 320 \\
\text { n.3 (N.Y. Sup. Ct. } \\
\text { 2013). }\end{array}$ & Notice & $\begin{array}{l}\text { Davis v. S. Nassau } \\
\text { Cmtys. Hosp., } 46 \\
\text { N.E.3d 563, } 572 \\
\text { (N.Y. 2015). }\end{array}$ \\
\hline $\begin{array}{l}\text { North } \\
\text { Carolina }\end{array}$ & & $\begin{array}{l}\text { Holleman v. } \\
\text { Aiken, } 668 \text { S.E.2d } \\
\text { 579, 584-85 (N.C. } \\
\text { Ct. App. 2008). }\end{array}$ & Notice & $\begin{array}{l}\text { Fussell v. N.C. } \\
\text { Farm Bureau Mut. } \\
\text { Ins. Co., Inc., } 695 \\
\text { S.E.2d 437, 441-42 } \\
\text { (N.C. 2010). }\end{array}$ \\
\hline $\begin{array}{l}\text { North } \\
\text { Dakota }\end{array}$ & $\begin{array}{l}\text { NO DEFINITIVE } \\
\text { CASES }\end{array}$ & $\begin{array}{l}\text { NO DEFINITIVE } \\
\text { CASES }\end{array}$ & Notice & $\begin{array}{l}\text { McColl Farms, } \\
\text { LLC v. Pflaum, } \\
837 \text { N.W.2d 359, } \\
367 \text { (N.D. 2013). }\end{array}$ \\
\hline Ohio & SPLIT & SPLIT & Notice & $\begin{array}{l}\text { State ex rel. Ohio } \\
\text { Civil Serv. Emps. } \\
\text { Ass'n. v. State, } 56 \\
\text { N.E.3d 913, } 918 \\
\text { (Ohio 2016). }\end{array}$ \\
\hline Oklahoma & & $\begin{array}{l}\text { Edelen v. Bd. of } \\
\text { Comm'rs, } 266 \\
\text { P.3d 660, } 663 \\
\text { (Okla. Ct. App. } \\
\text { 2011). }\end{array}$ & Notice & $\begin{array}{l}\text { State ex rel. Okla. } \\
\text { Corp. Comm'n v. } \\
\text { McPherson, } 232 \\
\text { P.3d } 458,464 \\
\text { (Okla. 2010). }\end{array}$ \\
\hline
\end{tabular}




\begin{tabular}{|c|c|c|c|c|}
\hline State & $\begin{array}{l}\text { Accepting } \\
\text { Plausibility }\end{array}$ & $\begin{array}{l}\text { Rejecting } \\
\text { Plausibility }\end{array}$ & $\begin{array}{l}\text { Current } \\
\text { Standard }\end{array}$ & Current Citation \\
\hline Oregon & $\begin{array}{l}\text { NO DEFINITIVE } \\
\text { CASES }\end{array}$ & $\begin{array}{l}\text { NO DEFINITIVE } \\
\text { CASES }\end{array}$ & Fact & $\begin{array}{l}\text { McDowell } \\
\text { Welding \& } \\
\text { Pipefitting, Inc. v. } \\
\text { U.S. Gypsum Co., } \\
193 \text { P.3d 9, } 17 \text { (Or. } \\
\text { 2008). }\end{array}$ \\
\hline Penn. & $\begin{array}{l}\text { NO DEFINITIVE } \\
\text { CASES }\end{array}$ & $\begin{array}{l}\text { NO DEFINITIVE } \\
\text { CASES }\end{array}$ & Fact & $\begin{array}{l}\text { Bricklayers of W. } \\
\text { Pa. Combined } \\
\text { Funds, Inc. v. } \\
\text { Scott's Dev. Co., } \\
625 \mathrm{~Pa} .26,46 \text { (Pa. } \\
2014) .\end{array}$ \\
\hline $\begin{array}{l}\text { Rhode } \\
\text { Island }\end{array}$ & $\begin{array}{l}\text { NO DEFINITIVE } \\
\text { CASES }\end{array}$ & $\begin{array}{l}\text { NO DEFINITIVE } \\
\text { CASES }\end{array}$ & Notice & $\begin{array}{l}\text { Chhun v. Mortg. } \\
\text { Elec. Registration } \\
\text { Sys., Inc., } 84 \text { A.3d } \\
\text { 419, 421-22 (R.I. } \\
\text { 2014). }\end{array}$ \\
\hline $\begin{array}{l}\text { South } \\
\text { Carolina }\end{array}$ & $\begin{array}{l}\text { NO DEFINITIVE } \\
\text { CASES }\end{array}$ & $\begin{array}{l}\text { NO DEFINITIVE } \\
\text { CASES }\end{array}$ & Fact & $\begin{array}{l}\text { Charleston Cty. } \\
\text { Sch. Dist. v. } \\
\text { Harrell, } 713 \text { S.E.2d } \\
\text { 604, } 607 \text { (S.C. } \\
\text { 2011). }\end{array}$ \\
\hline $\begin{array}{l}\text { South } \\
\text { Dakota }\end{array}$ & $\begin{array}{l}\text { Sisney v. Best } \\
\text { Inc., } 754 \text { N.W.2d } \\
\text { 804, } 809 \text { (S.D. } \\
\text { 2008). }\end{array}$ & & Plausibility & $\begin{array}{l}\text { Hernandez v. } \\
\text { Avera Queen of } \\
\text { Peace Hosp., } 886 \\
\text { N.W.2d 338, 344- } \\
45 \text { (S.D. 2016). }\end{array}$ \\
\hline Tenn. & & $\begin{array}{l}\text { Webb v. Nashville } \\
\text { Area Habitat for } \\
\text { Humanity, Inc., } \\
346 \text { S.W.3d 422, } \\
425 \text { (Tenn. 2011). }\end{array}$ & Notice & $\begin{array}{l}\text { Webb v. Nashville } \\
\text { Area Habitat for } \\
\text { Humanity, Inc., } \\
346 \text { S.W.3d 422, } \\
425 \text { (Tenn. 2011). }\end{array}$ \\
\hline Texas & SPLIT & SPLIT & Notice & $\begin{array}{l}\text { In re Lipsky, } 460 \\
\text { S.W.3d 579, } 590 \\
\text { (Tex. 2015). }\end{array}$ \\
\hline Utah & $\begin{array}{l}\text { NO DEFINITIVE } \\
\text { CASES }\end{array}$ & $\begin{array}{l}\text { NO DEFINITIVE } \\
\text { CASES }\end{array}$ & Notice & $\begin{array}{l}\text { Am. W. Bank } \\
\text { Members, L.C. v. } \\
\text { State, } 342 \text { P.3d } \\
\text { 224, } 230 \text { (Utah } \\
\text { 2014). }\end{array}$ \\
\hline Vermont & & $\begin{array}{l}\text { Colby v. } \\
\text { Umbrella, } 955 \\
\text { A.2d 1082, } 1086 \\
\text { n.1 (Vt. 2008). }\end{array}$ & Notice & $\begin{array}{l}\text { Mahoney v. Tara, } \\
\text { LLC, } 107 \text { A.3d } \\
887,892 \text { (Vt. } \\
\text { 2014). }\end{array}$ \\
\hline Virginia & $\begin{array}{l}\text { NO DEFINITIVE } \\
\text { CASES }\end{array}$ & $\begin{array}{l}\text { NO DEFINITIVE } \\
\text { CASES }\end{array}$ & Notice & $\begin{array}{l}\text { Preferred Sys. } \\
\text { Sols., Inc. v. GP } \\
\text { Consulting, LLC, } \\
732 \text { S.E.2d 676, } \\
689 \text { (Va. 2012). }\end{array}$ \\
\hline Wash. & & $\begin{array}{l}\text { McCurry v. Chevy } \\
\text { Chase Bank, FSB, } \\
233 \text { P.3d } 861 \\
\text { (Wash. 2010) (en } \\
\text { banc). }\end{array}$ & Notice & $\begin{array}{l}\text { McCurry v. Chevy } \\
\text { Chase Bank, FSB, } \\
233 \text { P.3d } 861 \\
\text { (Wash. 2010) (en } \\
\text { banc). }\end{array}$ \\
\hline $\begin{array}{l}\text { West } \\
\text { Virginia }\end{array}$ & & $\begin{array}{l}\text { Roth v. } \\
\text { DeFeliceCare, } \\
\text { Inc., } 700 \text { S.E.2d } \\
\text { 183, } 189 \text { n.4 (W. } \\
\text { Va. 2010). }\end{array}$ & Notice & $\begin{array}{l}\text { Roth v. } \\
\text { DeFeliceCare, Inc., } \\
700 \text { S.E.2d 183, } \\
189 \text { n.4 (W. Va. } \\
\text { 2010). }\end{array}$ \\
\hline
\end{tabular}




\begin{tabular}{|l|l|l|l|l|}
\hline State & $\begin{array}{l}\text { Accepting } \\
\text { Plausibility }\end{array}$ & $\begin{array}{l}\text { Rejecting } \\
\text { Plausibility }\end{array}$ & $\begin{array}{l}\text { Current } \\
\text { Standard }\end{array}$ & Current Citation \\
\hline Wisconsin & $\begin{array}{l}\text { Data Key Partners } \\
\text { v. Permira }\end{array}$ & & Plausibility & $\begin{array}{l}\text { Data Key Partners } \\
\text { v. Permira }\end{array}$ \\
& Advisers LLC, & & & Advisers LLC, 849 \\
& 849 N.W.2d 693, & & & N.W.2d 693, 699- \\
& 699-701 (Wis. & & & 701 (Wis. 2014). \\
& 2014 ). & & & \\
\hline Wyoming & NO DEFINITIVE & NO DEFINITIVE & Notice & Ridgerunner, LLC \\
& CASES & CASES & & v. Meisinger, 297 \\
& & & & P.3d 110, 114 \\
& & & \\
& & & \\
\end{tabular}


APPENDIX 2

\section{SUMMARY JUDGMENT CASES}

\begin{tabular}{|c|c|c|c|}
\hline State & $\begin{array}{l}\text { Rejecting Celotex (in } \\
\text { whole or part) }\end{array}$ & Accepting Celotex & $\begin{array}{l}\text { Other Relevant } \\
\text { Decisions }\end{array}$ \\
\hline Alabama & & $\begin{array}{l}\text { Ex parte Gen. Motors } \\
\text { Corp., } 769 \text { So. } 2 \mathrm{~d} 903 \\
\text { (Ala. 1999). }\end{array}$ & $\begin{array}{l}\text { Previously rejected: } \\
\text { Berner v. Caldwell, } \\
543 \text { So. 2d } 686 \text { (Ala. } \\
1989 \text { ). }\end{array}$ \\
\hline Alaska & & $\begin{array}{l}\text { Greywolf v. Carroll, } 151 \\
\text { P.3d 1234, } 1241 \text { (Alaska } \\
\text { 2007). }\end{array}$ & $\begin{array}{l}\text { Moffatt v. Brown, } 751 \\
\text { P.2d 939, } 943 \text { (Alaska } \\
\text { 1988) (criticizing } \\
\text { Liberty Lobby). }\end{array}$ \\
\hline Arizona & & $\begin{array}{l}\text { Orme Sch. v. Reeves, } 802 \\
\text { P.2d } 1000 \text { (Ariz. 1990) (en } \\
\text { banc). }\end{array}$ & \\
\hline Arkansas & & $\begin{array}{l}\text { Wallace v. Broyles, } 961 \\
\text { S.W.2d } 712 \text { (Ark. 1998). }\end{array}$ & \\
\hline California & & $\begin{array}{l}\text { Aguilar v. Atl. Richfield } \\
\text { Co., } 24 \text { P.3d } 493 \text { (Cal. } \\
\text { 2001) (“[W]e believe that } \\
\text { summary judgment law in } \\
\text { this state now conforms, } \\
\text { largely but not completely, } \\
\text { to its federal counterpart, } \\
\text { as clarified and liberalized } \\
\text { in Celotex, Anderson, and } \\
\text { Matushita."). }\end{array}$ & $\begin{array}{l}\text { Previously rejected: } \\
\text { Krantz v. BT Visual } \\
\text { Images, LLC, 107 Cal. } \\
\text { Rptr. 2d 209 (Cal. Ct. } \\
\text { App. 2001) } \\
\text { (chronicling dispute } \\
\text { among California } \\
\text { courts). }\end{array}$ \\
\hline Colorado & & $\begin{array}{l}\text { Cont'l Air Lines, Inc. v. } \\
\text { Keenan, 731 P.2d } 708 \\
\text { (Colo.1987) (en banc). }\end{array}$ & \\
\hline Conn. & $\begin{array}{l}\text { Thomas v. A.O. Smith } \\
\text { Corp., No. } \\
\text { CV105029385S, } 2012 \text { WL } \\
\text { 695550 (Conn. Super. Ct. } \\
\text { 2012); Adams v. Laval, } \\
\text { CV126026706S, 2014 WL } \\
\text { 7271874 (Conn. Super. Ct. } \\
\text { 2012); Tangari v. Am. } \\
\text { Optical Corp., No. } \\
\text { CV065003634S, 2013 WL } \\
\text { 6171421 (Conn. Super. Ct. } \\
\text { 2013); Waste Conversion } \\
\text { Techns., Inc. v. Midstate } \\
\text { Recovery, LLC, No. } \\
\text { AANCV044000948, } 2008 \\
\text { WL 5481231 (Conn. } \\
\text { Super. Ct. 2008). }\end{array}$ & & \\
\hline Delaware & & $\begin{array}{l}\text { Burkhart v. Davies, } 602 \\
\text { A.2d } 56 \text { (Del. 1991). }\end{array}$ & \\
\hline $\begin{array}{l}\text { Dist. of } \\
\text { Columbia }\end{array}$ & & $\begin{array}{l}\text { Claytor v. Owens-Corning } \\
\text { Fiberglass Corp., 662 A.2d } \\
\text { 1374, } 1381 \text { (D.C. 1995); } \\
\text { Doe v. Safeway, Inc., 88 } \\
\text { A.3d 131 (D.C. 2014); } \\
\text { Hollins v. Fed. Nat'l. } \\
\text { Mortg. Ass'n, 760 A.2d } \\
\text { 563 (D.C. 2000). }\end{array}$ & \\
\hline
\end{tabular}




\begin{tabular}{|c|c|c|c|}
\hline State & $\begin{array}{l}\text { Rejecting Celotex (in } \\
\text { whole or part) }\end{array}$ & Accepting Celotex & $\begin{array}{l}\text { Other Relevant } \\
\text { Decisions }\end{array}$ \\
\hline Florida & $\begin{array}{l}\text { 5G's Car Sales, Inc. v. Fla. } \\
\text { Dep't. of Law Enf't, } 581 \\
\text { So. 2d } 212 \text { (Fla. Dist. Ct. } \\
\text { App. 3d Dist. 1991); Byrd } \\
\text { v. BT Foods, Inc., 948 So. } \\
\text { 2d } 921 \text { (Fla. Dist. Ct. App. } \\
\text { 4th Dist. 2007); Lich v. } \\
\text { N.C.J. Inv. Co., 728 So. 2d } \\
\text { 1191 (Fla. Dist. Ct. App. } \\
\text { 2d Dist. 1999); Green v. } \\
\text { CSX Transp., Inc., 626 So. } \\
\text { 2d } 974 \text { (Fla. Dist. Ct. App. } \\
\text { 1st Dist. 1993) (per } \\
\text { curiam). }\end{array}$ & & \\
\hline Georgia & $\begin{array}{l}\text { First Union Nat'l. Bank of } \\
\text { Ga. v. J. Reisbaum Co., } \\
378 \text { S.E.2d } 317 \text { (Ga. Ct. } \\
\text { App. 1989); Hepner v. S. } \\
\text { Ry. Co., 356 S.E.2d } 30 \\
\text { (Ga. Ct. App. 1987). }\end{array}$ & & \\
\hline Hawai'i & & $\begin{array}{l}\text { Ralston v. Yim, } 92 \text { P.3d } \\
1276 \text { (Haw. 2013). }\end{array}$ & \\
\hline Idaho & & $\begin{array}{l}\text { Chandler v. Hayden, } 215 \\
\text { P.3d } 485 \text { (Idaho 2009). }\end{array}$ & $\begin{array}{l}\text { G\&M Farms v. Funk } \\
\text { Irrigation Co., 808 } \\
\text { P.2d } 851 \text { (Idaho 1991) } \\
\text { (criticizing Liberty } \\
\text { Lobby). }\end{array}$ \\
\hline Illinois & & $\begin{array}{l}\text { Ganci v. Washington, 745 } \\
\text { N.E.2d } 42 \text { (Ill. App. Ct. 4th } \\
\text { Dist. 2001); Hutchcraft v. } \\
\text { Indep. Mech. Indus., 726 } \\
\text { N.E.2d } 1171 \text { (Ill. App. Ct. } \\
\text { 4th Dist. 2000); Estate of } \\
\text { Henderson v. W.R. Grace } \\
\text { Co., 541 N.E.2d } 805 \text { (Ill. } \\
\text { App. Ct. 3d Dist. 1989); } \\
\text { Willett v. Cessna Aircraft } \\
\text { Co., 851 N.E.2d } 626 \text { (Ill. } \\
\text { App. Ct. 1st Dist. } 2006 \text { ); } \\
\text { Jiotis v. Burr Ridge Park } \\
\text { Dist., 934 N.E.3d } 514 \text { (Ill. } \\
\text { App. Ct. 2d Dist. 2014). }\end{array}$ & \\
\hline Indiana & $\begin{array}{l}\text { Jarboe v. Landmark Cmty. } \\
\text { Newspapers of Ind., Inc., } \\
644 \text { N.E.2d } 118 \text { (Ind. } \\
\text { 1994); Dennis v. } \\
\text { Greyhound Lines, Inc., } 831 \\
\text { N.E.2d } 171 \text { (Ind. Ct. App. } \\
\text { 2005). }\end{array}$ & & \\
\hline Iowa & & $\begin{array}{l}\text { Wilson v. Darr, } 553 \\
\text { N.W.2d 579, } 582 \text { (Iowa } \\
\text { 1996); Griglione v. Martin, } \\
525 \text { N.W.2d 810, } 813 \\
\text { (Iowa 1994). }\end{array}$ & \\
\hline Kansas & & $\begin{array}{l}\text { Unified Sch. Dist. No. 232, } \\
\text { Johnson Cty. v. CWD } \\
\text { Invs., LLC, 205 P.3d } 1245 \\
\text { (Kan. 2009). }\end{array}$ & \\
\hline
\end{tabular}




\begin{tabular}{|c|c|c|c|}
\hline State & $\begin{array}{l}\text { Rejecting Celotex (in } \\
\text { whole or part) }\end{array}$ & Accepting Celotex & $\begin{array}{l}\text { Other Relevant } \\
\text { Decisions }\end{array}$ \\
\hline Kentucky & $\begin{array}{l}\text { Steelvest, Inc. v. Scansteel } \\
\text { Serv. Ctr., Inc., } 807 \\
\text { S.W.2d } 476 \text { (Ky. 1991). }\end{array}$ & & \\
\hline Louisiana & & $\begin{array}{l}\text { Samaha v. Rau, } 977 \text { So. 2d } \\
880 \text { (La. 2008) (based on } \\
1997 \text { amendments to La. } \\
\text { Code Civ. Proc. Ann. art. } \\
966 \text { (2016)); Hardy v. } \\
\text { Bowie, 744 So. 2d } 606 \\
\text { (La. 1999) (same). }\end{array}$ & $\begin{array}{l}\text { Previously rejected: } \\
\text { Sassone v. Elder, 626 } \\
\text { So. 2d 345 (La. 1993) } \\
\text { (superseded by } \\
\text { amendments to La. } \\
\text { Code Civ. Proc. Ann. } \\
(2016) \text { ). }\end{array}$ \\
\hline Maine & & $\begin{array}{l}\text { Corey v. Norman, Hanson } \\
\text { \& DeTroy, } 742 \text { A.2d } 933 \\
\text { (Me. 1999). }\end{array}$ & \\
\hline Maryland & & $\begin{array}{l}\text { Beatty v. Trailmaster } \\
\text { Prods., Inc., 625 A.2d } \\
1005 \text { (Md. 1993); Yamaner } \\
\text { v. Orkin, 529 A.2d } 361 \\
\text { (Md. 1987). }\end{array}$ & \\
\hline Mass. & & $\begin{array}{l}\text { Kourouvacilis v. Gen. } \\
\text { Motors Corp., 716, } 575 \\
\text { N.E.2d } 734 \text { (Mass. 1991). }\end{array}$ & \\
\hline Michigan & & $\begin{array}{l}\text { Guinto v. Cross and Peters } \\
\text { Co., 547 N.W.2d } 314 \\
\text { (Mich. 1996); McCart v. J. } \\
\text { Walter Thompson, Inc., } \\
\text { 469 N.W.2d } 284 \text { (Mich. } \\
\text { 1991). }\end{array}$ & \\
\hline Minnesota & & $\begin{array}{l}\text { DLH, Inc. v. Russ, } 566 \\
\text { N.W.2d } 60 \text { (Minn. 1997). }\end{array}$ & \\
\hline Miss. & & $\begin{array}{l}\text { Galloway v. Travelers Ins. } \\
\text { Co., } 515 \text { So. 2d 678, 683- } \\
84 \text { (Miss. 1987); Fruchter } \\
\text { v. Lynch Oil Co., 522 So. } \\
\text { 2d } 195 \text { (Miss. 1988); } \\
\text { Ladnier v. Hester, } 98 \text { So. } \\
\text { 3d } 1025 \text { (Miss. 2012). }\end{array}$ & \\
\hline Missouri & $\begin{array}{l}\text { ITT Commercial Fin. v. } \\
\text { Mid-Am. Marine Supply } \\
\text { Corp., 854 S.W.2d 371 } \\
\text { (Mo. 1993) (en banc); see } \\
\text { also Powel v. Chaminade } \\
\text { Coll. Preparatory, Inc., } 197 \\
\text { S.W.3d 576 (Mo. 2006) } \\
\text { (en banc). }\end{array}$ & & \\
\hline Montana & & $\begin{array}{l}\text { Monroe v. Cogswell } \\
\text { Agency, 234 P.3d } 79 \\
\text { (Mont. 2010). }\end{array}$ & \\
\hline Nebraska & & $\begin{array}{l}\text { Roskop Dairy, LLC v. } \\
\text { GEA Farm Techs., Inc., } \\
871 \text { N.W.2d } 776 \text { (Neb. } \\
\text { 2015); Anderson v. Serv. } \\
\text { Merch. Co., Inc., } 485 \\
\text { N.W.2d } 170 \text { (Neb. 1992). }\end{array}$ & \\
\hline Nevada & & $\begin{array}{l}\text { Cuzze v. Univ. \& Cmty. } \\
\text { Coll. Sys. of Nev., 172 } \\
\text { P.3d } 131 \text { (Nev. 2007); }\end{array}$ & \\
\hline
\end{tabular}




\begin{tabular}{|c|c|c|c|}
\hline State & $\begin{array}{l}\text { Rejecting Celotex (in } \\
\text { whole or part) }\end{array}$ & Accepting Celotex & $\begin{array}{l}\text { Other Relevant } \\
\text { Decisions }\end{array}$ \\
\hline $\begin{array}{l}\text { Nevada } \\
\text { (cont.) }\end{array}$ & & $\begin{array}{l}\text { Clauson v. Lloyd, } 743 \text { P.2d } \\
631 \text { (Nev. 1987); Wood v. } \\
\text { Safeway, Inc., 121 P.3d } \\
1026 \text { (Nev. 2005). }\end{array}$ & \\
\hline $\begin{array}{l}\text { New } \\
\text { Hampshire }\end{array}$ & & $\begin{array}{l}\text { Pennichuck Corp. v. City } \\
\text { of Nashua, } 886 \text { A.2d } 1014 \\
\text { (N.H. 2005); Pennichuck } \\
\text { Corp. v. City of Nashua, } \\
2004 \text { WL 1950458 (N.H. } \\
\text { Super. Ct. 2004). }\end{array}$ & \\
\hline $\begin{array}{l}\text { New } \\
\text { Jersey }\end{array}$ & & $\begin{array}{l}\text { Brill v. Guardian Life Ins. } \\
\text { Co. of Am., } 666 \text { A.2d } 146 \\
\text { (N.J. 1995). }\end{array}$ & $\begin{array}{l}\text { Previously rejected } \\
\text { Liberty Lobby: Dairy } \\
\text { Stores, Inc. v. Sentinel } \\
\text { Publ'g Co., 516 A.2d } \\
220 \text { (N.J. 1986). }\end{array}$ \\
\hline $\begin{array}{l}\text { New } \\
\text { Mexico }\end{array}$ & $\begin{array}{l}\text { Romero v. Philip Morris } \\
\text { Inc., } 242 \text { P.3d } 280 \text { (N.M. } \\
\text { 2010). }\end{array}$ & & \\
\hline New York & $\begin{array}{l}\text { Yun Tung Chow v. Reckitt } \\
\text { \& Colman, Inc., 950 } \\
\text { N.E.2d } 113 \text { (N.Y. 2011) } \\
\text { (Smith, J., concurring) } \\
\end{array}$ & & \\
\hline $\begin{array}{l}\text { North } \\
\text { Carolina }\end{array}$ & & $\begin{array}{l}\text { Scarborough v. Dillard's } \\
\text { Inc., } 693 \text { S.E.2d } 640 \text { (N.C. } \\
\text { 2011). }\end{array}$ & $\begin{array}{l}\text { Previously rejected: } \\
\text { Metts v. Piver, } 401 \\
\text { S.E.2d } 407 \text { (N.C. Ct. } \\
\text { App. 1991). } \\
\end{array}$ \\
\hline $\begin{array}{l}\text { North } \\
\text { Dakota }\end{array}$ & & $\begin{array}{l}\text { Rooks v. Robb, } 871 \\
\text { N.W.2d } 468 \text { (N.D. 2015); } \\
\text { Steinbach v. State, } 658 \\
\text { N.W.2d } 355 \text { (N.D. 2003). }\end{array}$ & \\
\hline Ohio & & $\begin{array}{l}\text { Dresher v. Burt, } 662 \\
\text { N.E.2d } 264 \text { (Ohio 1996); } \\
\text { Wing v. Anchor Media, } \\
\text { Ltd. of Tex., } 570 \text { N.E.2d } \\
1095 \text { (Ohio 1991). }\end{array}$ & \\
\hline Oklahoma & $\begin{array}{l}\text { Iglehart v. Bd. of Cty. } \\
\text { Comm'rs, } 60 \text { P.3d } 497 \\
\text { (Okla. 2002); Kating v. } \\
\text { City of Pryor ex rel. Mun. } \\
\text { Util. Bd. f Pryor, } 977 \text { P.2d } \\
\text { 1142 (Okla. Civ. App. } \\
\text { 1998). }\end{array}$ & & \\
\hline Oregon & $\begin{array}{l}\text { Jones v. Gen. Motors } \\
\text { Corp., } 939 \text { P.2d } 608 \text { (Or. } \\
\text { 1997). }\end{array}$ & & \\
\hline Penn. & & $\begin{array}{l}\text { Ertel v. Patriot-News Co., } \\
674 \text { A.2d } 1038 \text { (Pa. 1996). }\end{array}$ & \\
\hline $\begin{array}{l}\text { Rhode } \\
\text { Island }\end{array}$ & & $\begin{array}{l}\text { Lavoie v. N.E. Knitting, } \\
\text { Inc., } 918 \text { A.2d } 225 \text { (R.I. } \\
\text { 2007). }\end{array}$ & \\
\hline $\begin{array}{l}\text { South } \\
\text { Carolina }\end{array}$ & & $\begin{array}{l}\text { Baughman v. AT \& T, } 410 \\
\text { S.E.2d } 537 \text { (S.C. 1991). }\end{array}$ & \\
\hline $\begin{array}{l}\text { South } \\
\text { Dakota }\end{array}$ & & $\begin{array}{l}\text { U.S. Bank Nat'l. Ass'n v. } \\
\text { Scott, } 673 \text { N.W.2d } 646 \\
\text { (S.D. 2003); One Star v. } \\
\text { Sisters of St. Francis, } 752 \\
\text { N.W.2d } 668 \text { (S.D. 2008). }\end{array}$ & \\
\hline
\end{tabular}




\begin{tabular}{|c|c|c|c|}
\hline State & $\begin{array}{l}\text { Rejecting Celotex (in } \\
\text { whole or part) }\end{array}$ & Accepting Celotex & $\begin{array}{l}\text { Other Relevant } \\
\text { Decisions }\end{array}$ \\
\hline Tenn. & & $\begin{array}{l}\text { Rye v. Women’s Care Ctr., } \\
477 \text { S.W.3d } 235 \text { (Tenn. } \\
\text { 2015). }\end{array}$ & $\begin{array}{l}\text { Previously rejected: } \\
\text { Hannan v. Alltel } \\
\text { Publ'g Co., } 270 \\
\text { S.W.3d } 1 \text { (Tenn. } \\
\text { 2008). }\end{array}$ \\
\hline Texas & $\begin{array}{l}\text { Casso v. Brand, } 776 \\
\text { S.W.2d 551 (Tex. 1989) } \\
\text { (partially superseded by } \\
\text { TEX. R. CIV. P. 166a(i)); } \\
\text { see also Huckabee v. Time } \\
\text { Warner Entm't Co., L.P., } \\
\text { 19 S.W.3d 413 (Tex. 2000) } \\
\text { (criticizing Liberty Lobby). }\end{array}$ & & $\begin{array}{l}\text { Casso's objections to } \\
\text { Celotex were partially } \\
\text { overruled by TEX. R. } \\
\text { CIV. P. 166a(i), as } \\
\text { amended in } 1997 .\end{array}$ \\
\hline Utah & $\begin{array}{l}\text { Orvis v. Johnson, } 177 \text { P.3d } \\
600 \text { (Utah 2008); Harline } \\
\text { v. Barker, } 912 \text { P.2d } 433 \\
\text { (Utah 1996); see also } \\
\text { Jones \& Trevor Mktg., Inc. } \\
\text { v. Lowry, 284 P.3d } 630 \\
\text { (Utah 2012). }\end{array}$ & & \\
\hline Vermont & & $\begin{array}{l}\text { Estate of Alden v. Dee, } 35 \\
\text { A.3d } 950 \text { (Vt. 2011); } \\
\text { Poplaski v. Lamphere, } 565 \\
\text { A.2d } 1326 \text { (Vt. 1989). }\end{array}$ & \\
\hline Virginia & $\begin{array}{l}\text { Realstar Realtors, LLC v. } \\
\text { Glenn ex rel. Smith, No. } \\
\text { CL99-186, 2001 WL } \\
\text { 587489 (Va. Cir. Ct. May } \\
\text { 23, 2001); Bhalala \& Shah, } \\
\text { Inc. v. Quik Out Mkt., Inc., } \\
\text { No. 131309, 1994 WL } \\
\text { 1031171 (Va. Cir. Ct. } \\
\text { 1004); Harleysville Mut. } \\
\text { Ins. Co. v. Capital GMC } \\
\text { Trucks, Inc., No. LT-2254- } \\
\text { 2, 1993 WL 945924 (Va. } \\
\text { Cir. Ct. 1993). }\end{array}$ & & \\
\hline Wash. & & $\begin{array}{l}\text { Young v. Key Pharm., } \\
\text { Inc., } 770 \text { P.2d } 182 \text { (Wash. } \\
\text { 1989) (en banc). }\end{array}$ & \\
\hline $\begin{array}{l}\text { West } \\
\text { Virginia }\end{array}$ & & $\begin{array}{l}\text { Williams v. Precision Coil, } \\
\text { Inc., 459 S.E.2d } 329 \text { (W. } \\
\text { Va. 1995); Crain v. } \\
\text { Lightner, 364 S.E.2d } 778 \\
\text { (W. Va. 1987). }\end{array}$ & \\
\hline Wisconsin & & $\begin{array}{l}\text { Yahnke v. Carson, } 613 \\
\text { N.W.2d } 102 \text { (Wis. 2000); } \\
\text { Transp. Ins. Co., Inc. v. } \\
\text { Hunzinger Constr. Co., } \\
507 \text { N.W.2d } 136 \text { (Wis. Ct. } \\
\text { App. 1993). }\end{array}$ & \\
\hline Wyoming & & $\begin{array}{l}\text { Franks v. Olson, } 975 \text { P.2d } \\
588 \text { (Wyo. 1999). }\end{array}$ & $\begin{array}{l}\text { Parker v. Haller, } 751 \\
\text { P.2d } 372 \text { (Wyo. 1988) } \\
\text { (criticizing Liberty } \\
\text { Lobby). }\end{array}$ \\
\hline
\end{tabular}

